Habitat use, nest success, and management recommendations for grassland birds of the Canaan Valley National Wildlife Refuge, West Virginia

\author{
Kelly Ann Warren \\ West Virginia University
}

Follow this and additional works at: https://researchrepository.wvu.edu/etd

\footnotetext{
Recommended Citation

Warren, Kelly Ann, "Habitat use, nest success, and management recommendations for grassland birds of the Canaan Valley National Wildlife Refuge, West Virginia" (2001). Graduate Theses, Dissertations, and Problem Reports. 1276.

https://researchrepository.wvu.edu/etd/1276

This Thesis is protected by copyright and/or related rights. It has been brought to you by the The Research Repository @ WVU with permission from the rights-holder(s). You are free to use this Thesis in any way that is permitted by the copyright and related rights legislation that applies to your use. For other uses you must obtain permission from the rights-holder(s) directly, unless additional rights are indicated by a Creative Commons license in the record and/ or on the work itself. This Thesis has been accepted for inclusion in WVU Graduate Theses, Dissertations, and Problem Reports collection by an authorized administrator of The Research Repository @ WVU. For more information, please contact researchrepository@mail.wvu.edu.
} 


\section{HABITAT USE, NEST SUCCESS, AND MANAGEMENT \\ RECOMMENDATIONS FOR GRASSLAND BIRDS OF THE CANAAN VALLEY \\ NATIONAL WILDLIFE REFUGE, WEST VIRGINIA}

Kelly A. Warren

Thesis submitted to the College of Agriculture, Forestry and Consumer Sciences

at West Virginia University

in partial fulfillment of the requirements

for the degree of

Master of Science

in

Wildlife and Fisheries Resource Management

James T. Anderson, Ph.D., Chair

Robert C. Whitmore, Ph.D.

Linda Butler, Ph.D.

Division of Forestry

Morgantown, WV 2001

Keywords: bobolink, eastern meadowlark, farmland, grassland birds, hayfields, pastures, savannah sparrows, West Virginia

Copyright 2001 Kelly A. Warren 


\title{
ABSTRACT \\ HABITAT USE, NEST SUCCESS AND MANAGEMENT RECOMMENDATIONS FOR GRASSLAND BIRDS OF THE CANAAN VALLEY NATIONAL WILDLIFE REFUGE, WEST VIRGINIA
}

\author{
KELLY A. WARREN
}

Grassland bird populations have been declining due to increased habitat fragmentation, urbanization, and conversion of farmlands to other uses throughout the United States. However, idle hayfields and pastures in the eastern United States may provide adequate nesting habitat for grassland species displaced from their native habitat. The objectives of this study were to: 1) compare grassland bird abundance, diversity, and richness of species between 3 idle hayfields and 3 pastures and between mowed and unmowed treatments, and 2) compare grassland bird nest success between hayfields and pastures, and between mowed and unmowed treatments on the Canaan Valley National Wildlife Refuge, West Virginia during the summers of 1999-2000. A total of 27 species was found on the refuge. The predominant grassland species were bobolinks (Dolichonyz oryzivorus), savannah sparrows (Passerculus sandwichensis), and eastern meadowlarks (Sturnella magna). Overall bird abundance differed between mowed ( $\overline{\mathrm{x}}=0.61$; SE $=0.09)$ and unmowed $(\overline{\mathrm{x}}=0.32 ; \mathrm{SE}=0.06)$ treatments in pastures $(P=0.033)$. Grassland bird diversity differed between mowed plots of hayfields ( $\bar{x}=0.85 ; \mathrm{SE}=0.21$ ) and pastures $(\overline{\mathrm{x}}=$ 1.57; $\mathrm{SE}=0.26)(P=0.026)$. Mayfield nest survival did not differ between nests found in hayfields and pastures, and mowed and unmowed treatments. While nest success did not differ between mowed and unmowed treatments, mowing these fields at the conclusion of the breeding season will provide long term advantages to grassland birds nesting on the refuge. Additionally, grassland birds appeared to be responding to the vegetative structure and vertical diversity within fields rather than field size. Management should focus on removal of internal edges (i.e., remnant fencelines, hedgerows, and wind breaks) found throughout the grasslands on the refuge. 
For

Louise N. Lightener "Aunt Lou" and Roy G. Bokey "Pap Pap"

Two people I was very lucky to have in my life for so long.

You are greatly missed. 


\section{Acknowledgements}

I thank the following agencies that funded this project: United States Fish and Wildlife Service, West Virginia Division of Natural Resources, and West Virginia University. Especially, Kevin DesRoberts, Ken Sturm, Thomas Gardner for their help, advice, and cooperation at the Canaan Valley National Wildlife Refuge.

Thank you, Craig Rhodes, Scott Reilly, and my parents John and Carol Warren for your field assistance. Craig, thank you for the countless hours spent in the field collecting data, sorting invertebrates, and for your beautiful photography. Scott, thank you for the time spent sorting invertebrates. John and Carol, thank you lending a hand when I needed a lift and for the time you both spent collecting vegetation data with me.

I thank each of my committee members for their contribution to this project. I thank James Anderson, my major professor, for his support and assistance, and his patience and ability to endure all of my questions. I also thank Robert Whitmore and Linda Butler for their advice, expertise, and support throughout this project. Finally, I want to thank all of my friends for their support and advice over the past 2 years. 


\section{TABLE OF CONTENTS:}

CHAPTER 1. LIST OF TABLES …………………................................................... vii

CHAPTER I. LIST OF FIGURES ……................................................................. vii

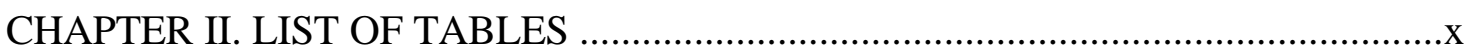

CHAPTER II. LIST OF FIGURES …............................................................................

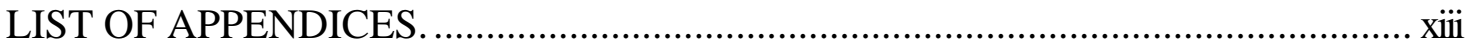

CHAPTER I

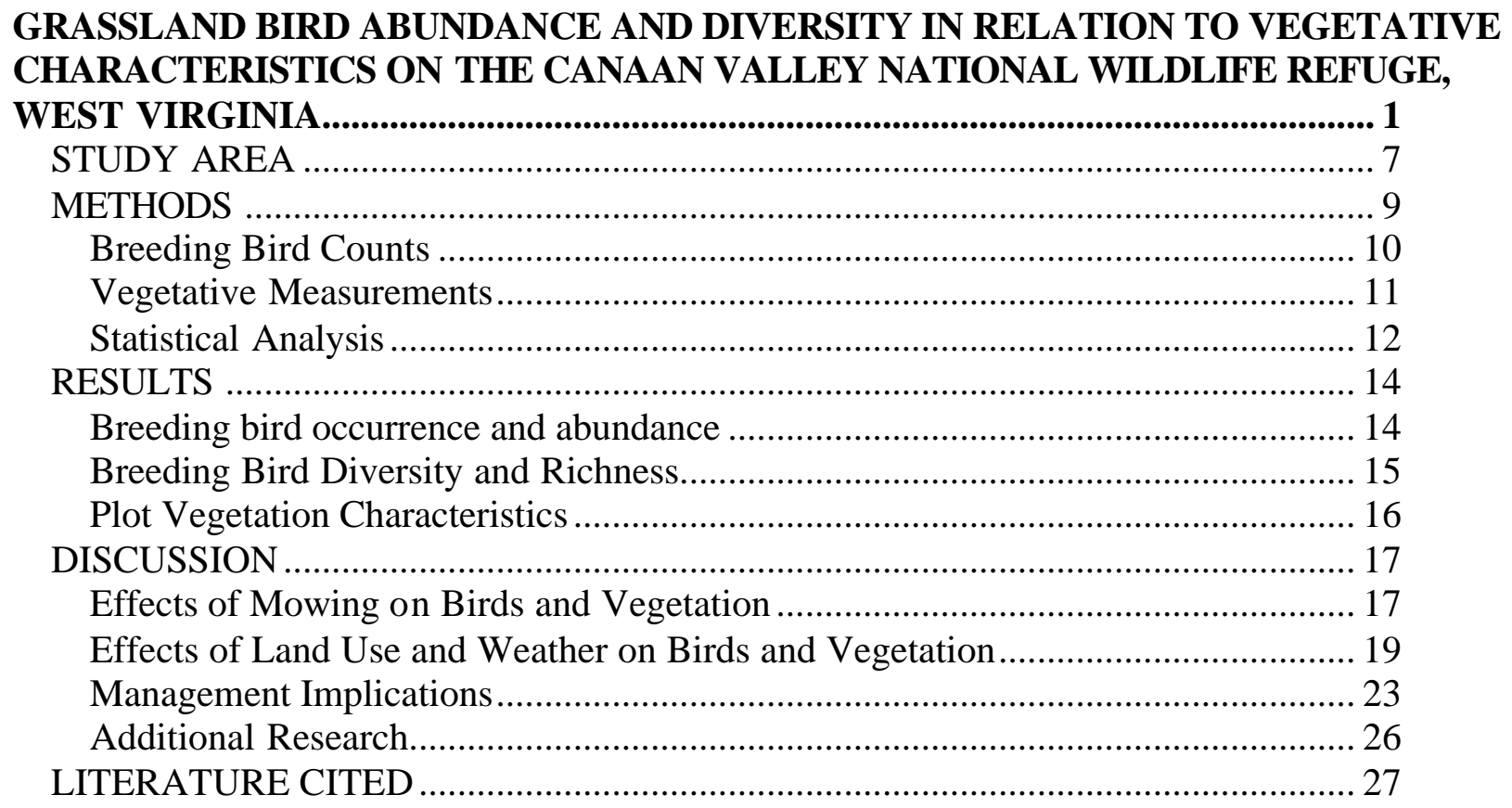

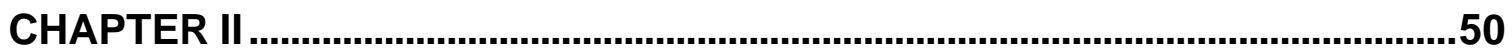

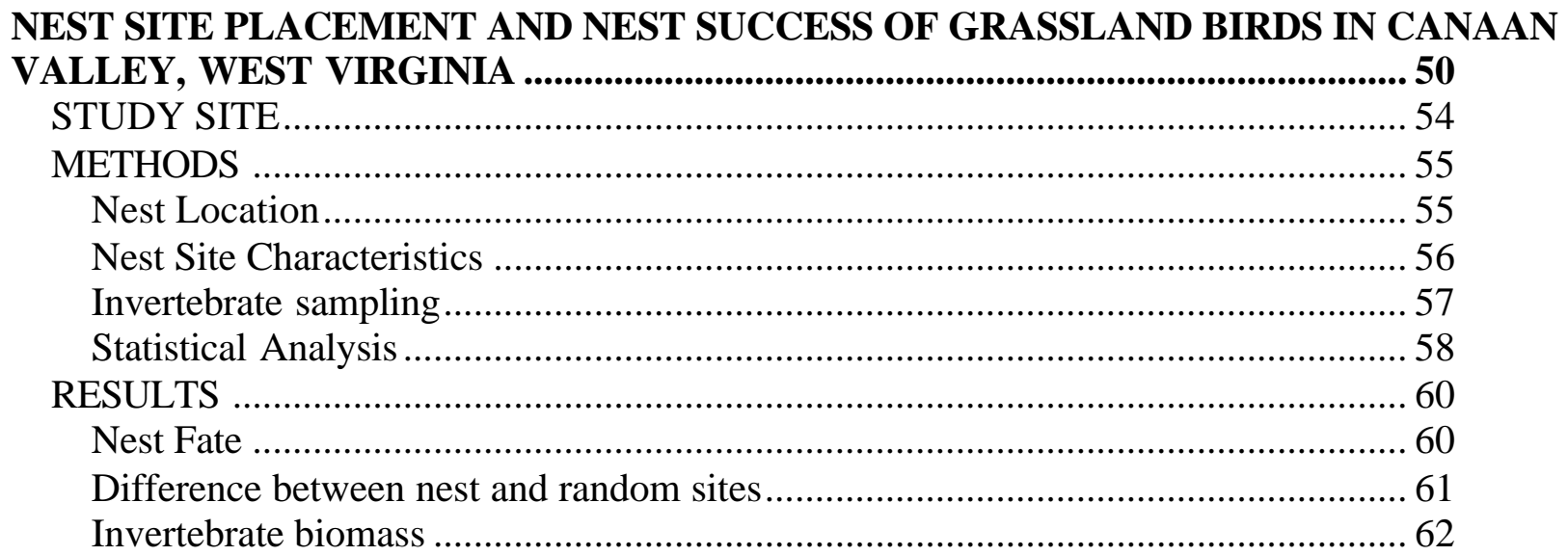




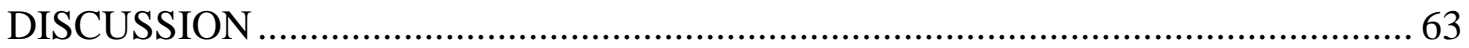

Nest Success Rates on Mowed Treatments and Habitat Types ............................. 63

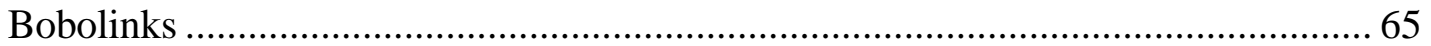

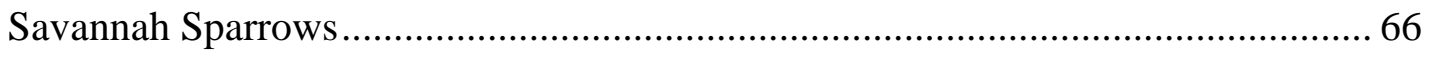

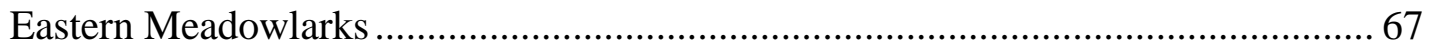

Red-winged Blackbird ................................................................................ 69

Invertebrate Food Availability for Grassland Nesting Species and their Nestlings . 70

Management Implications ............................................................................... 71

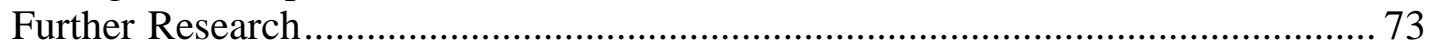

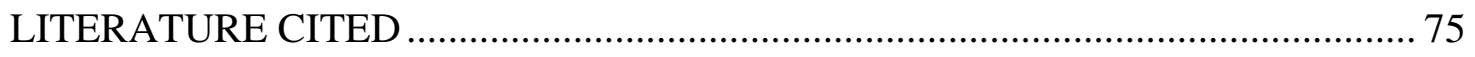




\section{CHAPTER 1. LIST OF TABLES}

Table 1. Breeding Bird Survey (BBS) grassland bird population trends (1966-1998) for species found in West Virginia on the Canaan Valley National Wildlife Refuge, Tucker County (Sauer et al. 2000).

Table 2. Breeding grassland bird density (number of birds/ha), diversity, and richness between mowed and unmowed treatments on the Canaan Valley National Wildlife Refuge, West Virginia, May-August $2000^{\mathrm{a}}$ 36

Table 3. Breeding grassland bird density (number of birds/ha), diversity, and richness between hayfields and pastures on the Canaan Valley National Wildlife Refuge, West Virginia, MayAugust 1999-2000

Table 4. Vegetative characteristics for mowed and unmowed treatments on the Canaan Valley

National Wildlife Refuge, Tucker County, West Virginia, June-August 2000. 38

Table 5. Vegetative characteristics for hayfields and pastures on the Canaan Valley National

Wildlife Refuge, Tucker County, West Virginia, June-August 1999-2000. 


\section{CHAPTER I. LIST OF FIGURES}

Figure 1. Canaan Valley National Wildlife Refuge grassland study sites in Tucker County, West Virginia for 1999 and 2000. 40

Figure 2. Monthly precipitation totals (cm) for 1999 and 2000, and normal monthly rainfall values for Canaan Valley, Tucker County, West Virginia 1999-2000.

Figure 3. Total birds counted for weekly bird surveys on the Canaan Valley National Wildlife Refuge, Tucker County, West Virginia, May-August 1999-2000. Week 1 is the 2nd week in May and Week 13 is the 2nd week in August. 42

Figure 4. Breeding grassland bird density for all species combined among months on the Canaan Valley NWR, Tucker County, West Virginia, May-August 1999-2000. The same letter above bars indicate no difference $(P>0.05)$ among months.

Figure 5. Breeding grassland bird diversity based on Shannon-Weiner diversity index (Zar 1999) between treatments within habitat types on the Canaan Valley NWR, Tucker County, West Virginia, May-August 2000. The same letter above bars indicates no difference $(P>0.05)$ between treatments.

Figure 6. Breeding grassland bird diversity based on Shannon-Weiner diversity index (Zar 1999) among months on the Canaan Valley NWR, Tucker County, West Virginia, May-August 19992000. The same letter above bars indicates no difference $(P>0.05)$ among months. .... 45 Figure 7. Breeding grassland bird richness between years on the Canaan Valley NWR, Tucker County, West Virginia, May-August 1999-2000. The same letter above bars indicates no difference $(P>0.05)$ between years. 
Figure 8. Breeding grassland bird richness by months on the Canaan Valley National Wildlife Refuge, Tucker County, West Virginia, May-August 1999-2000. The same letter above bars indicates no difference $(P>0.05)$ among months.

Figure 9. Comparison of percent canopy and percent litter between years on the Canaan Valley National Wildlife Refuge, Tucker County, WV 1999-2000. The same letter above bars indicates no difference $(P>0.05)$ between years. 48 Figure 10. Comparison of vertical density $(\mathrm{cm})$ and maximum height $(\mathrm{cm})$ between years on the Canaan Valley National Wildlife Refuge, Tucker County, West Virginia 1999-2000. The same letter above bars ind icates no difference $(P>0.05)$ between years. 49 


\section{CHAPTER II. LIST OF TABLES}

Table 1. Five dominant vegetative species (\%) found at bobolink, eastern meadowlark, savannah sparrow, and red-winged blackbird nest sites on the Canaan Valley National Wildlife Refuge, Tucker County, West Virginia, 1999-2000. * Indicates vegetative species is not among the 5 most dominant vegetative species for that particular grassland nesting bird.

Table 2. Number of nests found per year (percent success/depredation) of grassland bird nests found on the Canaan Valley National Wildlife Refuge, Canaan Valley, West Virginia for the 1999 and 2000 breeding seasons.

Table 3. Average clutch size of nests for grassland species found on the Canaan Valley National Wildlife Refuge, Tucker County, West Virginia 1999-2000. 84

Table 4. Number of nests, Mayfield nesting success, and daily survival rates of all grassland birds found on each tract and habitat type on the Canaan Valley National Wildlife Refuge, Tucker County, West Virginia 1999-2000.

Table 5. Number of nests, exposure days, Mayfield nesting success, daily nest survival of all grassland birds found nesting on each tract and treatment on the Canaan Valley National Wildlife Refuge, Tucker County, West Virginia 1999-2000. 86

Table 6: Number of active nests, exposure days, Mayfield nesting success, and daily survival rate of bobolinks, eastern meadowlarks, savannah sparrows, and red-winged blackbirds (the most common species found on the grassland portion of the Canaan Valley NWR, Canaan Valley, West Virginia in 1999 and 2000. 87

Table 7. Vegetative variables that were different between nest sites and random locations using stepwise discriminant analysis to determine which variables best fit the model on the Canaan Valley National Wildlife Refuge, Tucker County, West Virginia 1999-2000. 
Table 8. Vegetative variables that were different between successful and unsuccessful nests using stepwise discriminant analysis to determine which variables best fit the model on the Canaan Valley National Wildlife Refuge, Tucker County, West Virginia 1999-2000. ................ 90 


\section{CHAPTER II. LIST OF FIGURES}

Figure 1. Canaan Valley National Wildlife Refuge grassland study sites in Tucker County, West

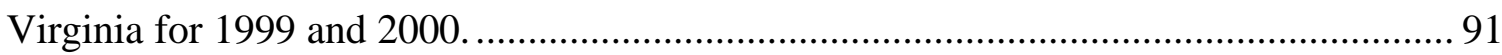

Figure 2. Monthly precipitation totals (cm) for 1999 and 2000, and normal monthly rainfall values for Canaan Valley, Tucker County, West Virginia 1999-2000.................................... 92 


\section{LIST OF APPENDICES.}

Appendix Ia. Vegetation (\%) found in mowed and unmowed treatments on the Canaan Valley

National Wildlife Refuge, Tucker County, West Virginia 2000. 94

Appendix Ib. Vegetation (\%) found on mowed and unmowed treatments within hayfields and pastures on the Canaan Valley National Wildlife Refuge, Tucker County, West Virginia 2000.

Appendix Ic. Vegetation (\%) found on hayfields and pastures on the Canaan Valley National Wildlife Refuge, Tucker County, West Virginia 1999-2000. 104

Appendix II. Maximum number of birds during a weekly bird surveys on 6 grassland plots on the Canaan Valley National Wildlife Refuge, Tucker County, West Virginia 1999-2000. . 110 Appendix IIIa. Breeding grassland bird density (number/ha), diversity, and richness by treatment and month for hayfields on the Canaan Valley National Wildlife Refuge, Tucker County, West Virginia 2000. 114 Appendix IIIb. Breeding grassland bird density (number/ha), diversity, and richness by treatment and month for pastures on the Canaan Valley National Wildlife Refuge, Tucker County, West Virginia 2000. 115 Appendix IIIc. Breeding grassland bird density (number/ha), diversity, and richness by month for hayfields and pastures on the Canaan Valley National Wildlife Refuge, Tucker County, WV, 2000.

Appendix IIId. Breeding grassland bird density (number/ha), diversity, and richness by month for mowed and unmowed treatments on the Canaan Valley National Wildlife Refuge, Tucker County, West Virginia 2000. 
Appendix IIIe. Breeding grassland bird density (number/ha), diversity, and richness by habitat types and month for 1999 on the Canaan Valley National Wildlife Refuge, Tucker County, West Virginia 1999-2000. 118 Appendix IIIf. Breeding grassland bird density (number/ha), diversity, and richness by habitat types and month for 2000 unmowed treatments on the Canaan Valley National Wildlife Refuge, Tucker County, West Virginia 1999-2000........................................................... 119 Appendix IIIg. Breeding grassland bird density (number/ha), diversity, and richness by habitat types and month for 1999 and 2000 on the Canaan Valley National Wildlife Refuge, Tucker County, West Virginia, May-August 1999-2000. 120 Appendix IIIh. Breeding grassland bird density (number/ha), diversity, and richness by habitat types and month on the Canaan Valley National Wildlife Refuge, Tucker County, West Virginia, May-August,1999-2000.

Appendix IVa: Means ( $\overline{\mathrm{x}}$ ), standard errors (SE), and test statistics of vegetative variables measured on hayfields between mowed and unmowed portions on the Canaan Valley National Wildlife Refuge, Tucker County, West Virginia, June-August, 2000.

Appendix IVb. Means ( $\overline{\mathrm{x}}$ ), standard errors (SE), and test statistics of vegetative variables measured on pastures between mowed and unmowed portions on the Canaan Valley National Wildlife Refuge, Tucker County, West Virginia, June-August, 2000. 123

Appendix IVd: Means ( $\overline{\mathrm{x}}$ ), standard errors (SE), test statistics of vegetative variables measured between mowed and unmowed treatments on the Canaan Valley National Wildlife Refuge, Tucker County, West Virginia, June-August, 2000. 
Appendix IVe. Mean ( $\bar{x})$, standard error (SE), and test statistics of all vegetative characteristics measured on hayfields and pastures during 1999 on the Canaan Valley National Wildlife Refuge, Tucker County, West Virginia, June-August, 1999-2000 ............................................. 126 Appendix IVf. Mean ( $\bar{x}$ ), standard error (SE), and test statistics of all vegetative characteristics measured on hayfields and pastures during 1999 on the Canaan Valley National Wildlife Refuge, Tucker County, West Virginia, June-August, 1999-2000.

Appendix IVg: Mean ( $\bar{x}$ ), standard error (SE), and test statistics of all vegetative characteristics measured during 1999 and 2000 for each month on the Canaan Valley National Wildlife Refuge, Tucker County, West Virginia. 128 Appendix IVh: Mean ( $\overline{\mathrm{x}}$ ), standard error (SE), and test statistics of all vegetative characteristics measured during between hayfields and pastures for each month on the Canaan Valley National Wildlife Refuge, Tucker County, West Virginia 1999-2000. Appendix V. Vegetation (\%) found at nest sites on the Canaan Valley National Wildlife Refuge, Tucker County, West Virginia, 1999-2000. 130

Appendix VIa. Mean $(\bar{x})$ and standard error (SE) of vegetative characteristics found at bobolink nest sites and random sample locations on the Canaan Valley National Wildlife Refuge, Tucker County, West Virginia, 1999-2000. An asterisk denotes those variables that were not entered into the discriminant function analysis model. 132 Appendix VIb. Mean ( $\bar{x}$ ) and standard error (SE) of vegetative characteristics found at eastern meadowlark nest sites and random sample locations on the Canaan Valley National Wildlife Refuge, Tucker County, West Virginia 1999-2000. An asterisk denotes those variables that were not entered into the discriminant function analysis model. 133 
Appendix VIc. Mean ( $\overline{\mathrm{x}})$ and standard error (SE) of vegetative characteristics found at savannah sparrow nest sites and random sample locations on the Canaan Valley National Wildlife Refuge, Tucker County, West Virginia 1999-2000. An asterisk denotes those variables that were not entered into the discriminant function analysis model. 134

Appendix VId. Mean ( $\overline{\mathrm{x}})$ and standard error (SE) of vegetative characteristics found at redwinged blackbird nest sites and random sample locations on the Canaan Valley National Wildlife Refuge, Tucker County, West Virginia, 1999-2000. An asterisk denotes those variables that were not entered into the discriminant function analysis model. 135

Appendix VId. Mean ( $\overline{\mathrm{x}}$ ) and standard error (SE) of vegetative characteristics found at successful and unsuccessful bobolink nest sites on the Canaan Valley National Wildlife Refuge, Tucker County, West Virginia, 1999-2000. An asterisk denotes those variables that were not entered into the discriminant function analysis model. 136 Appendix VIe. Mean ( $\bar{x})$ and standard error (SE) of vegetative characteristics found at successful and unsuccessful red-winged blackbird nest sites on the Canaan Valley National Wildlife Refuge, Tucker County, West Virginia 1999-2000. An asterisk denotes those variables that were not entered into the discriminant function analysis model. 137 Appendix VIf. Mean and standard error of vegetative characteristics found at successful and unsuccessful savannah sparrow nest sites on the Canaan Valley National Wildlife Refuge, Tucker County, West Virginia 1999-2000. An asterisk denotes those variables that were not entered into the discriminant function analysis model. 138 Appendix VII. Biomass (g) of invertebrates found on the Canaan Valley National Wildlife Refuge, Tucker County, West Virginia, 1999-2000 139 


\section{CHAPTER I}

\section{GRASSLAND BIRD ABUNDANCE AND DIVERSITY IN RELATION TO \\ VEGETATIVE CHARACTERISTICS ON THE CANAAN VALLEY NATIONAL WILDLIFE REFUGE, WEST VIRGINIA}

Abstract: Due to increased habitat fragmentation, urbanization, and conversion of farmlands to other uses, grassland birds have declined throughout the United States. Several species of grassland birds that were historically common and abundant in the northeastern United States also show this trend. The objective of this study was to compare grassland bird abundance, diversity, and richness of species between 3 idle hayfields and 3 idle pastures, and 5 mowed and 6 unmowed grasslands. This study was conducted in the Canaan Valley National Wildlife Refuge, West Virginia on 295 ha of grassland habitat. During the summers of 1999 and 2000, I used strip transects to compare breeding grassland bird diversity and abundance between idle hayfields and idle pastures. At the conclusion of the 1999 field season, around $50 \%$ of each field was mowed to manipulate the vegetation. The predominant grassland species were bobolinks (Dolichonyz oryzivorus), savannah sparrows (Passerculus sandwichensis), and eastern meadowlarks (Sturnella magna). Overall bird abundance differed between mowed ( $\overline{\mathrm{x}}=$ $0.61 ; \mathrm{SE}=0.09)$ and unmowed $(\overline{\mathrm{x}}=0.32 ; \mathrm{SE}=0.06)$ treatments in pastures $(P=0.033)$. Grassland bird diversity differed between mowed plots of hayfields ( $\overline{\mathrm{x}}=0.85$; $\mathrm{SE}=$ $0.21)$ and pastures $(\overline{\mathrm{x}}=1.57 ; \mathrm{SE}=0.26)(P=0.026)$. Litter depth and standing dead vegetation were higher in mowed than unmowed treatments $(P<0.023)$. Maximum

This thesis is in the style of the Journal of Wildlife Management 
height and litter depth differed between hayfields and pastures $(P<0.021)$. Differences in vegetative structure characteristics appear to have an effect on territory selection for savannah sparrows and eastern meadowlarks. Vegetation manipulation including mowing, grazing, and/or prescribed burning is essential to maintain grassland ecosystems for grassland bird populations in West Virginia.

\section{JOURNAL OF WILDLIFE MANAGEMENT 00(0):000-000}

Key words : bobolink, eastern meadowlark, farmland, grassland bird abundance, hayfields, mowing, pastures, species diversity, savannah sparrow.

Grassland bird populations of North America have experienced steeper, more consistent declines than any other bird populations (Kantrud and Higgins 1992, Knopf 1994, Jones and Vickery 1997). Declines in grassland birds and their habitats indicate that greater conservation attention for grassland habitats and their associated breeding bird populations are required (Herkert et al. 1996). In North America, populations of at least 13 species of grassland birds declined significantly between 1966 and 1996 (Peterjohn and Sauer 1999, Vickery et al. 1999). Native grassland habitat has been severely altered by agricultural practices, and many grasslands are among the continent's most endangered ecosystems (Vickery et al. 1999). It is estimated that habitat loss has exceeded $80 \%$ in most areas, and where land is well suited for crops, less than $0.1 \%$ of native prairie remains (Vickery et al. 1999). However, in the midwest and northeast United States, agricultural lands have provided adequate breeding habitat for many species, particularly bobolinks and eastern meadowlarks (Vickery et al. 1999). 
In the northeast, grassland and shrubland birds have been identified as habitatcommunity groups showing the most widespread and persistent declines in abundance (Wells and Rosenberg 1999). Historically, little attention has been focused on grassland bird recovery programs in the northeast because of the idea that most grassland species are not native to the region, but instead invaded the area from western prairies after forests were cleared for agriculture (Askins 1997, Wells and Rosenberg 1999). However, there is evidence prior to European settlement that open grassland and shrubland habitats such as meadows and croplands composed a significant proportion of the pre-European arrival landscape (Askins 1997, Wells and Rosenberg 1999). Native Americans created grasslands by clearing land for firewood harvesting and planting of maize fields, and burning to enhance hunting areas (Askins 1997). Although grassland species in the eastern United States were noted by only the earliest ornithologists, historical range expansion of these species has been well documented. These widespread and abundant species include: upland sandpipers (Bartramia longicauda), grasshopper sparrows (Ammodramus savannarum), bobolinks, eastern meadowlarks, and others (Askins 1997). All scientific and common names of birds follow the nomenclature of the American Ornithologists' Union (1998). In the northeast, a shift in agricultural technology, farmland abandonment and movement to the west, more frequent haycropping rotations, loss of habitat, and an increase in human population have been cited as reasons for recent grassland bird declines (Bollinger et al. 1990, Herkert et al. 1996, Jones and Vickery 1997, Norment et al. 1999).

The North American Breeding Bird Survey (BBS) indicates that grassland birds showed the most consistent rate of decline of any group of birds monitored (Sauer et al. 
2000). Fewer than $30 \%$ of these grassland species showed an increasing population (Sauer et al. 2000). In the northeast, horned larks (Eremophila alpestris), savannah sparrows, grasshopper sparrows, Henslow's sparrows (Ammodramus henslowii), vesper sparrows (Pooecetes gramineus), bobolinks, and eastern meadowlarks showed a significant negative trend based on BBS data (Sauer et al. 2000, Wells and Rosenberg 1999). Most grassland bird populations in the northeast, and specifically in West Virginia, are declining according to BBS data from 1966-1998 (Table 1). Many species of grassland birds are area sensitive and are vulnerable to loss of grassland habitat (Norment et al. 1999). In the northeast, grassland habitat has declined by about $60 \%$ since the 1930s (Vickery et al. 1994, Norment et al. 1999).

In West Virginia, grassland bird studies have previously focused on populations present at reclaimed mine sites (Whitmore and Hall 1978). Grassland bird species (e.g., northern harriers [Circus cyaneus], short-eared owls [Asio flammeus], and Henslow's sparrows) presently occupy and breed on reclaimed surface coal mines dominated by grass in western Pennsylvania, West Virginia, Ohio, and Indiana (Vickery et al. 1999). These areas appear to be providing important refugia for these species (Vickery et al. 1999). Pastures, reclaimed mines, and logging operations have provided an opportunity for displaced midwestern grassland bird species to expand their ranges (Whitmore and Hall 1978). Grassland species of the reclaimed mine community included vesper sparrows, savannah sparrows, horned larks, red-winged blackbirds (Agelaius phoeniceus), and eastern meadowlarks (Wray et al. 1978). Recently little research has been conducted on grassland bird success in West Virginia, particularly on farmlands. While limited information does exist for reclaimed mine sites and current studies are 
being conducted on those sites, the extent of grassland bird use of idle and active farmlands has not been studied in the state of West Virginia although grassland bird presence of these habitat types has been documented (Buckelew and Hall 1994). Because reclaimed mine sites and farmlands are the most abundant areas available to grassland birds in West Virginia it is important to understand how to manage these sites to promote grassland bird success.

Additionally, idle farmlands may provide adequate habitat for grassland birds in the east (Bollinger et al. 1990), specifically in the Appalachian region. Idle hayfields and pastures are increasing in the east due to changes in farming practices and the purchase of farmlands for other uses. These new and changing habitats present excellent opportunities to enhance the quality of habitat for declining grassland birds (Farris and Cole 1981). Grassland species previously found in pastures and hayfields of West Virginia include bobolinks, grasshopper sparrows, field sparrows (Spizella pusilla), and chipping sparrows (Spizella passerina) (Wray et al. 1978). If hayfields and pastures are not maintained, habitat for grassland species will be depleted and may eventually disappear in West Virginia.

Mowing fields can aid in providing quality habitat by controlling woody vegetation, lowering vegetative height, and reducing litter build-up (Sample and Hoffman 1989). This will set back succession and provide nesting habitat for grassland nesting birds. However, the frequency and timing of mowing can directly lead to grassland bird population declines. Most hayfields are mowed too early for successful reproduction and fields are planted with a single species lowering habitat diversity (Jones and Vickery 1997). Mowing early in the season disrupts nesting and will ultimately lead to nest 
failure. Unfortunately, late season mowing often decreases the value of hay to farmers. In the eastern United States, agricultural practices initially led to the range expansions of grassland bird species; however, hay-cropping may ultimately be reducing population densities and abundance (Bollinger et al. 1990, Frawley and Best 1991, Jones and Vickery 1997). However, mowing can be used as an important management tool for grassland bird populations if conducted while species are not on their breeding grounds or at the conclusion of their nesting season.

In West Virginia, the Canaan Valley National Wildlife Refuge (CVNWR), located in Tucker County, may provide an important agricultural landscape for local obligative and facultative grassland bird population maintenance (Vickery et al. 1999). The objectives of my study were to: 1) compare breeding bird abundance, diversity, and richness of species between idle hayfields and idle pastures and mowed and unmowed treatments; 2) estimate composition of vegetation and its relation to grassland bird abundance, diversity, and richness of idle hayfields and idle pastures; and 3) develop management recommendations for the grasslands on the CVNWR. I tested the hypothesis that grassland bird abundance and diversity and vegetative structure were similar between hayfields and pastures and between mowed and unmowed treatments. I hypothesized that: 1) there would be no differences between hayfields and pastures for grassland bird abundance and diversity; 2) grassland bird species diversity would be higher at sites with more edge and woody cover; 3) there would be fewer grassland birds in mowed treatments at the beginning of the 2000 season than in the unmowed treatments; and 4) vegetative composition would differ between hayfields and pastures 
and mowed and unmowed treatments because of different management practices

previously used.

\section{STUDY AREA}

The study was conducted on CVNWR in Canaan Valley (Tucker County), West Virginia (Figure 1). The valley is around $24 \mathrm{~km}$ long and 3-6 km wide and is oriented on a northeast-southwest axis. The valley is at an elevation of 960-990 $\mathrm{m}$ above sea level and is surrounded by mountains up to $305 \mathrm{~m}$ above the valley floor (United States Fish and Wildlife Service 1979). The valley consists of a large wetland system ( 2,438 ha) consisting of meadows, boggy terrain, beaver ponds, and boreal forests.

The climate of the valley consists of cold winter temperatures and cool summers. The climate and vegetation have been related to similar climates in northern New York, Vermont, New Hampshire, and the northern half of Maine (Thornthwaite 1948). Flora within the valley is composed of plants with northern ranges and distributions and for some species Canaan Valley is the southern most extent of their range (Fortney 1993). There is a relatively short growing season with an average of 92 frost-free days from 31 May through 1 September (Vogelmann 1978). Summer temperatures are moderate with an average from $24-26^{\circ} \mathrm{C}$ during the day and $10-13^{\circ} \mathrm{C}$ at night. Ground fogs generally form dissipating shortly after sunrise. In a normal year, total rainfall is about $113.89 \mathrm{~cm}$ (National Oceanic and Atmospheric Administration 1999). During 1999, total yearly rainfall was $95.63 \mathrm{~cm}$ with lower rainfall in June-September when compared to rainfall accumulation in a normal year (Figure 2). Additionally, West Virginia experienced a statewide drought during the summer 1999. In 2000, total rainfall $(112.57 \mathrm{~cm})$ was similar to rainfall in a normal year (Figure 2) (National Oceanic and Atmospheric 
Administration 2000). There was a difference of $21.88 \mathrm{~cm}$ total rainfall during the months of May-August for 1999 and 2000.

The valley was first visited by explorers in 1746 and settlers arrived as early as 1800 (Vogelmann 1978). Prior to logging the valley consisted of large red spruce (Picea rubens), with a dense understory of rhododendron (Rhododendron maximum) (Vogelmann 1978). Other species associated with boreal climates or relict flora of more northern climates included: balsam fir (Abies balsamea), hemlock (Tsuga canadensis), yellow birch (Betula lutea), sugar maple (Acer saccharum), beech (Fagus grandifolia), small cranberry (Vaccinium oxycoccos), creeping snowberry (Gaultheria hispidula), yellow avens (Geum strictum), sedge (Carex leptonervia), bulrush (Scirpus rubrotinctus), woolgrass (Scirpus atrocinctus), marsh marigold (Caltha palustris), and jack-in-the-pulpit (Arisaema stewardsonii) (Strausbaugh and Core 1977). Natural openings or glades, occurred in the forests, which consisted of grass balds or bogs too wet for forestation. Deep layers of needles and other plant and animal matter accumulated and together with sphagnum moss (Lycopodium spp.) built up a humus-rich acid soil.

Beginning in the 1880 s the railroad made Canaan Valley more accessible and more susceptible to logging practices. Red spruce was cut leaving the valley completely bare. By 1920 few trees remained and lumbering activity throughout West Virginia severely declined. The microclimate changed and the soil dried creating a dry substrate where tree seedlings were unable to become established (Vogelmann 1978). Once forested bottomlands, have become boggy sphagnum bogs in wetter sites and haircap moss (Polytrichum spp.) hummocks on slightly drier ground (Fortney 1993). The drier 
uplands consisted of forb and grass meadows and some introduced weed species when the heavily burned area was planted with mixed grass seed (Vogelmann 1978).

Agriculture in Canaan Valley has predominantly been unsuccessful, although some farms do exist today. Most crops were unable to produce well in the short growing season and cattle have been the predominant form of livestock since the area was logged. Pastures and hayfields are found in the slightly drier southern portion of the valley. Currently, the CVNWR grasslands consist of dry upland areas, hawthorne (Crataegus spp.) savannahs, saturated wet meadows, and saturated scrub-shrub wetlands, which Vickery et al. (1999) includes in the broad definition of grassland systems. The dominant grassland vegetation present on the refuge consists of orchard grass (Dactylis glomerata), mountain oat grass (Danthonia compressa), sweet vernal grass (Anthoxanthum odoratum), quackgrass (Agropyron repens), timothy (Phleum pratense), bog goldenrod (Solidago uliginosa), wrinkle-leaved goldenrod (Solidago rugosa), cinquefoil (Potentilla spp.), St. John's Wort (Hypericum spp.), and narrow-leaved meadowsweet (Spirea alba) (Appendix I).

\section{METHODS}

The study was conducted on 6 grassland plots: Beall, Cortland, Freeland, Harper, Hertz, and Thompson. The grassland portion of the refuge is around 295 ha ( $\bar{x}=49.17$ ha/plot; $\mathrm{SE}=12.66$ ), and each plot was classified according to previous land use as idle hayfield (Beall [93 ha], Harper [73 ha], and Thompson [24 ha]) or idle pasture (Cortland [16 ha], Freeland [28 ha], and Hertz [61 ha]). At the conclusion of the 1999 grassland bird breeding season in late August, 50\% of the grassland portions of Beall, Cortland, Freeland, Harper, and Thompson were mowed to determine the effects of habitat 
manipulation on breeding bird success. Hertz was not mowed because the wet substrate was inaccessible for mowing equipment. Transects for surveys for birds and vegetation were placed on each plot $(n=6)$ and ran the length and width of each field. Placement was dependent on plot size and transects were located $50 \mathrm{~m}$ away from edges.

\section{Breeding Bird Counts}

I conducted strip transect surveys to estimate breeding bird densities following the methods of Franzreb (1981) and Best et al. (1997). I conducted bird counts on each tract from May to August 1999-2000. Surveys were conducted within 5 hours of sunrise during the period of peak bird activity (Gates 1995). Counts were not conducted when wind speeds exceeded $16 \mathrm{~km} / \mathrm{hr}$ or when it was raining (Best et al. 1997). The transects were walked once, per week, and all birds within $50 \mathrm{~m}$ of the transect were recorded, giving an effective strip width of $100 \mathrm{~m}$. Bird species, sex, and behavior (e.g., singing, calling) were recorded when possible to determine if birds were exhibiting nesting behavior. The transects were walked at a moderate pace to count individuals but fast enough to avoid counting the same individuals twice. Results of bird counts were converted to density (number birds/ha) estimates. Bird detectability problems were accounted for among species and habitats by using transect widths of 50-100 m which created a relatively unobstructed range for viewing birds in open habitats (Best et al. 1997). Additionally, special care was taken was taken to avoid double-counting individual birds by excluding birds flying overhead but not alighting within study fields (Best et al. 1997). 


\section{Vegetative Measurements}

I conducted vegetative sampling once per month from June to August of 19992000 following the methods of Best et al. (1997). Vertical density $(\mathrm{cm})$, maximum height $(\mathrm{cm})$, litter depth $(\mathrm{cm})$, and canopy coverage were measured using a Robel pole (Robel et al. 1970) and Daubenmire frame (Daubenmire 1959). The Robel pole, with a height of $1 \mathrm{~m}$, was used to obtain visual obstruction readings at $4 \mathrm{~m}$ away from the pole (Robel et al. 1970). The maximum height of vegetation was recorded in $\mathrm{cm}$ using the Robel pole. Vegetative canopy coverage was determined using a Daubenmire sampling frame (Daubenmire 1959). Total cover was determined on a nonoverlapping basis and classified into canopy coverage, litter coverage, and bare ground coverage. Canopy coverage was then classified into the following categories: living or standing-dead vegetation; and forbs, grasses, and woody vegetation (Best et al. 1997). Living and standing-dead vegetation equaled the percentage determined for canopy cover. Additionally, the forbs, grasses, and woody vegetation equaled the amount of percent canopy cover and the combined living and standing-dead vegetation percentage. Litter included all dead plant material laying on the soil surface, including decomposing material. Standing-dead vegetation included all dead plant material found above the litter layer and therefore was considered in maximum height and visual obstruction readings. Measurements were recorded every 5-20 m depending on transect size. Small plots $(<28$ ha) with little area to cover were sampled every $5 \mathrm{~m}$ and large plots ( $>16$ ha) with large amounts of area to cover were sampled every $20 \mathrm{~m}$. 


\section{Statistical Analysis}

For all birds observed during weekly counts, I calculated density (number of birds/ha) based on the average number of birds counted during a month. However, analyses were conducted for total birds and 3 target species (bobolinks, savannah sparrow, and eastern meadowlarks) to determine overall differences in total bird and target species densities. Bobolinks, savannah sparrows, and eastern meadowlarks were chosen because they were found on both habitat types (1999 and 2000) and treatments, and are declining grassland species. Grassland bird species diversity was obtained using the Shannon-Weiner diversity index:

$$
\text { Diversity }=\left(\mathrm{H}^{\prime}=n \log n \sum\left(f_{\mathrm{i}} \log f_{\mathrm{i}}\right) / n\right)
$$

(Shannon 1948, Zar 1999). In the diversity index formula: $n=$ sample size; and $f_{\mathrm{i}}=$ the number of observations. Diversity was calculated based on the maximum number of individuals of each species counted during each month. Species richness was calculated by determining the number of species per ha found on each plot.

During 2000, I used 3-way analysis of variance (ANOVA) to compare density, richness, and diversity (dependent variables) between treatments (mowed or unmowed), habitat types (pastures and hayfields), and months (May, June, July, and August) (independent variables). Following these analyses, data were analyzed using 3-way ANOVAs to compare density, richness, and diversity between habitat types (pastures and hayfields), years (1999 and 2000), and months (May, June, July, and August). If there was no difference between treatments based on 2000 data, estimates from each treatment within a field were combined, for all analyses on 1999-2000 data. If there was a 
difference between treatments in 2000 , only data from the unmowed portion of the fields were used in analyses of 1999-2000 data.

Habitat characteristics of plots were analyzed using 3-way multivariate analysis of variance (MANOVA) or 3-way ANOVA and the same independent variables used for bird density, richness, and diversity analyses. I analyzed vertical density, maximum height, and litter depth (dependent variables) using 3 separate ANOVAs. I used MANOVA to analyze: cover type (canopy, litter, and bare ground), growth state (standing live and standing dead), and vegetative type (forb, grass, and wood). These categories were formed because the variables within the groups were correlated.

All tests were significant at $P<0.05$. Following a significant ANOVA, I used Tukey's multiple comparison test to separate means. Data were checked for normality using Shapiro-Wilk Statistic and homogeneity of variances by plotting residuals (Cody and Smith 1991). I rank transformed density, richness, and diversity data because assumptions for parametric tests were not met (Conover and Iman 1981). An arcsine transformation was used on canopy, live vegetation, dead vegetation, wood, and vertical density, and a log tranformation was used on percent bare ground, vertical density, and maximum height to meet normality and homogeneous variance assumptions (Zar 1999). All interaction terms were placed in Appendices II-IV, and are only mentioned in the text if significant. Additionally, information on months and habitat types are presented for combined 1999-2000 data only. Interaction terms for 2000 are not presented because this information is redundant but was needed to test interaction terms and the effect of treatment. 


\section{RESULTS}

\section{Breeding bird occurrence and abundance}

There were 27 species found on the grassland during the weekly bird counts, 13 species were found on the refuge in 1999, and 27 species were found on the refuge in 2000 (Appendix II). Common species found on most grassland plots were bobolinks, savannah sparrows, eastern meadowlarks, and red-winged blackbirds. Species richness was high on the Cortland tract where a high edge-to-area ratio exists, this tract accounted for most of the edge species found during weekly surveys. Total number of individuals increased in late July and August (Figure 3). Additionally, large numbers of bobolinks and red-winged blackbirds were frequently encountered on the Freeland and Thompson tracts. At the end of breeding season, flocks of eastern meadowlarks were found on the Beall tract.

There was an interaction between habitat types and treatments $(F=7.35 ; \mathrm{df}=1$, $28 ; P=0.011)$ for total grassland bird density in 2000 (Table 2). A difference was detected in grassland bird densities found (number/ha)on mowed treatments in hayfields $(\overline{\mathrm{x}}=0.85, \mathrm{SE}=0.21)$ and pastures $(\overline{\mathrm{x}}=1.57, \mathrm{SE}=0.26)(F=5.86 ; \mathrm{df}=1,18 ; P=$

0.026). There was no difference detected between mowed ( $\bar{x}=1.57, \mathrm{SE}=0.26$ ) and unmowed $(\overline{\mathrm{x}}=1.45, \mathrm{SE}=0.61)$ treatments on pastures $(F=2.89 ; \mathrm{df}=1,18 ; P=$ 0.107). Additionally, there was no difference detected between mowed ( $\bar{x}=0.85, \mathrm{SE}=$ $0.21)$ and unmowed $(\overline{\mathrm{x}}=1.54, \mathrm{SE}=0.26)$ treatments on hayfields $(F=3.83$; df $=1,22$; $P=0.0630)$. Overall bird densities were similar between habitat types $(F=0.14 ; \mathrm{df}=1$, 32; $P=0.707$ ) for combined 1999-2000 data (Table 3). Grassland birds had a higher density in $1999(\bar{x}=8.25, \mathrm{SE}=2.58)$ than densities in $2000(\overline{\mathrm{x}}=1.50, \mathrm{SE}=0.32)(F=$ 
11.53; $\mathrm{df}=1,32 ; P=0.002)$. Differences also were detected among months $(F=3.83$; df $=3,32 ; P=0.009$ ) with July having a higher mean density than May, June, and August (Figure 4).

Bobolink densities were similar between treatments $(F=0.01$; $\mathrm{df}=1,28 ; P=$ 0.965) (Table 2). Bobolink densities were similar between years $(F=0.06$; $\mathrm{df}=1,32 ; P$ $=0.803)$, habitat types $(F=0.01 ; \mathrm{df}=1,32 ; P=0.908)$, and months $(F=0.17 ; \mathrm{df}=3$, 32; $P=0.915)$ for 1999 and 2000 combined data.

There was no difference in eastern meadowlark densities between treatments $(F=$ 1.96; $\mathrm{df}=1,28 ; P=0.172$ ) for 2000 . Higher eastern meadowlark densities were found on idle hayfields rather than idle pastures $(F=11.5 ; \mathrm{df}=1,32 ; P=0.002)$ (Table 3$)$. Densities were similar among years $(F=0.36 ; \mathrm{df}=1,32 ; P=0.551)$ and months $(F=$ $0.69 ; \mathrm{df}=3,32 ; P=0.563)$.

Higher savannah sparrow densities were detected on unmowed treatments rather than mowed treatments $(F=5.17$; df $=1,28 ; P=0.031)$ during 2000 (Table 2).

Savannah sparrow densities were similar between years $(F=0.52 ; \mathrm{df}=1,32 ; P=0.477)$, habitat types $(F=2.33 ; \mathrm{df}=1,32 ; P=0.137)$, and months $(F=3.04 ; \mathrm{df}=3,32 ; P=$ 0.068) for combined 1999 and 2000 data.

\section{Breeding Bird Diversity and Richness}

There was an interaction between treatments and habitat types $(F=10.52$; $\mathrm{df}=3$, $28 ; P=0.003$ ) for species diversity in 2000 . Grassland bird diversity was higher in mowed pastures than in unmowed pastures $(F=5.33$; df $=1,18 ; P=0.033)$ (Figure 5). Grassland bird diversity was similar between mowed hayfields and unmowed hayfields

$(F=2.01 ; \mathrm{df}=1,22 ; P=0.170)$ (Figure 5). There was no difference in species diversity 
for habitat types $(F=1.20 ; \mathrm{df}=1,32 ; P=0.281)$ or years $(F=3.31 ; \mathrm{df}=1,32 ; P=$ 0.078) for combined 1999-2000 data. However, species diversity was lower in August than other months $(F=6.52 ; \mathrm{df}=3,32 ; P=0.001)$ (Figure 6).

There was no difference between treatments $(F=0.49$; $\mathrm{df}=1,28 ; P=0.489)$ for grassland bird richness (Table 2). Pastures had higher species richness ( $\bar{x}=1.29, \mathrm{SE}=$ $0.14)$ than hayfields $(\overline{\mathrm{x}}=0.78, \mathrm{SE}=0.08)(F=12.98 ; \mathrm{df}=1,28 ; P=0.001)$ in 2000. There were no differences between habitat types for species richness $(F=0.36$; $\mathrm{df}=3$, 32; $P=0.782$ ) (Table 3). There were differences between years and among months for 1999 and 2000 data combined. A higher species richness was detected in 2000 than in $1999(F=23.32 ; \mathrm{df}=1,32 ; P<0.0001)$ (Figure 7$)$. August had a lower mean diversity than May, June, and July $(F=4.38 ; \mathrm{df}=3,32 ; P=0.011)$ (Figure 8$)$.

\section{Plot Vegetation Characteristics}

There were no differences between treatments for percent cover type (Wilks' $\ddot{~}=$ 0.786; $P=0.196$ ), percent vegetative type (Wilks' $\ddot{\mathrm{e}}=0.796 ; P=0.218$ ), vertical density $(F=2.37 ; \mathrm{df}=1,21 ; P=0.138)$, and maximum height $(F=0.20 ; \mathrm{df}=1,21 ; P=0.657)$ (Table 4). There were differences between treatments for percent growth state (Wilks' ë $=0.710 ; P=0.033)$. Standing dead vegetation was greater in unmowed than in mowed plots $(F=6.05 ; \mathrm{df}=1,21 ; P=0.023)($ Table 4$)$.

There were no differences between habitat types for percent ground cover (Wilks' $\ddot{\mathrm{e}}=0.865 ; P=0.352$ ), percent growth state (Wilks' $\ddot{\mathrm{e}}=0.926 ; P=0.411$ ), percent vegetative cover (Wilks' $\ddot{\mathrm{e}}=0.734 ; P=0.074)$ and vertical density $(F=0.62 ; \mathrm{df}=1,24$; $P=0.440$ ) for combined 1999-2000 data (Table 5). Vegetation was taller in pastures than in hayfields $(F=6.10 ; \mathrm{df}=1,24 ; P=0.021)$ (Table 5). However, litter was deeper in 
hayfields than in pastures $(F=15.95 ; \mathrm{df}=1,24 ; P<0.001)$ (Table 5). There were no differences between years for growth state (Wilks' $\ddot{e}=0.927 ; P=0.416$ ) and litter depth $(F=0.27 ; \mathrm{df}=1,24 ; P=0.606)$. Differences were detected between years for percent ground cover (Wilks' $\ddot{\mathrm{e}}=0.609 ; P=0.011$ ). Of the percent ground cover variables, bare ground did not differ between years $(F=1.26 ; \mathrm{df}=1,24 ; P=0.273)$, but percent canopy cover and percent litter were different. Percent canopy cover was higher in 2000 than in $1999(F=8.39 ; \mathrm{df}=1,24 ; P=0.008)$ (Figure 9), but percent litter was higher in 1999 than in $2000(F=12.33 ; \mathrm{df}=1,24 ; P=0.002)$ (Figure 9). Vertical density $(F=17.71$; df $=1,24 ; P<0.001)$ and maximum height $(F=24.95 ; \mathrm{df}=1,24 ; P<0.001)$ was higher in 2000 than in 1999 (Figure 10).

\section{DISCUSSION}

\section{Effects of Mowing on Birds and Vegetation}

Mowed hayfields had low bird densities when compared with the other treatments and habitat types. A difference in abundance may be influenced by a lack of cover needed for territory and nest site selection. Mowed plots had a decrease in percent standing dead vegetation when compared with unmowed plots. The higher percentage of standing dead vegetation in the unmowed plots, specifically in pastures, provided cover for individuals at the start of the season when maximum height and vertical density were lower. Similarly, Delisle and Savidge (1997) found increases in total bird abundance were related to increases in vertical density. On the refuge, standing dead vegetation found on unmowed treatments would contribute to increased vertical density early in the grassland bird breeding season. Savannah sparrows had lower densities on the mowed treatments indicating that this treatment did not provide suitable habitat for territory 
establishment or nest placement. Swanson (1998) noted that savannah sparrows prefer habitats with a well developed litter layer. The litter layer was removed or decreased in late August 1999 and the decrease in savannah sparrow densities on mowed plots in 2000 may have been in response to this altered vegetative characteristic. Additionally, standing dead vegetation found in unmowed plots provided song perches for breeding males that most likely increased savannah sparrow densities in unmowed plots (Vickery 1996). Territories established in Wisconsin has greater grass cover, deeper litter, lower forb density, and higher vegetation density (Wiens 1973, Wheelwright and Rising 1993).

In Saskatchewan, the number of savannah sparrow nesting pairs was consistently lower in grazed than ungrazed areas (Dale 1984); however, the litter layers in Canaan Valley appear to be adequate on hayfields and pastures. Savannah sparrows were found in every plot ranging from dry upland to moist wet meadows to shrub dominated habitats to areas with little interior and high amounts of edge. Similarly, Madden et al. (2000) found savannah sparrows in a wide range of habitats.

Additionally, there were differences in species diversity between combinations of treatments and habitat types. Diversity was higher on mowed pastures than on the other combinations of treatments and habitat types. While mowing is typically associated with decreases in bird diversity and abundance (Frawley and Best 1991), bird diversity on the refuge generally did not appear to be influenced by mowing treatment. However, shrubs on some of the pastures, in combination with the mowed areas may have created more edge and diversity of habitats. Additionally, because the grass continued to grow, a progression from sparse to heavy cover provided temporal variation in habitat structure. This may have provided proper requirements for more species through the summer. Each 
tract did not contribute equally to avian diversity. Specifically, the Cortland tract had a high edge-to-area ratio increasing the number of edge species found during the weekly bird counts. The high diversity of species present on Cortland may have been influenced by the degree of edge habitat available on that plot. Similarly, Vickery et al. (1994) found an increase in the number of edge species present on small fields (2-8 ha).

\section{Effects of Land Use and Weather on Birds and Vegetation}

Species richness was different in 2000 between habitat types with pastures having more species/ha than hayfields. The pastures in Canaan Valley provided a higher amount of edge habitat than hayfields and more edge-associated species were found. Pastures tended to have more shrubs increasing the amount of edge and vertical diversity for additional species. Species richness on pastures was possibly influenced by 1 high edgeto-area ratio plot (Cortland) with an associated increase in the number of edge associated species found during weekly bird counts. These species, including field sparrows (Spizella pusilla) northern cardinal (Cardinalis cardinalis), eastern towhee (Piplio erythrophthalmus), and indigo buntings (Passerina cyanea), are not target management species for the CVNWR. Vickery et al (1994) found similar results when comparing small plots (2-8 ha) to larger plots (> $64 \mathrm{ha}$ ). Differences in size classes lead to a patterns with edge species such as common yellowthroats (Geothlypis trichas) and song sparrows (Melospiza melodia) in smaller size classes and increases in area-dependent species in size classes greater than 32 ha (Vickery et al. 1994). This suggests areas on the refuge that are dominated by shrub cover are creating habitat for edge species and not target grassland species. 
Bobolink densities on the refuge were similar between hayfields and pastures, which contradicts the findings of similar studies. In some regions densities in hayfields were nearly 10 times greater than in natural grasslands (Graber and Graber 1963). In New York, 8 year old hayfields were preferred by bobolinks (Bollinger and Gavin 1992, Martin and Gavin 1995). Abundance in those older fields were 67\% greater than in lightly grazed pastures. Because both habitat types have been left idle for more than 8 years, differences in bobolink densities may be masked because fields are structurally similar. Prior to August of 1999, the hayfields on the refuge had remained idle since refuge acquisition, thus falling into the "old field" category. Both hayfields and pastures on the refuge were idle until the conclusion of the 1999 field season when half of each field was mowed. Both hayfields and pastures have exotic and native, tall grasses that seem to effectively simulate the now rare all natural tallgrass prairie. Bobolink habitat use was primarily found in hayfields or fields with exotic, tall grasses (Madden et al. 2000). These tall, rhizomatous, exotic grasses can be structurally similar to the native grass species they have replaced, and associated bird species have adopted this introduced vegetation as breeding habitat (Madden et al. 2000).

Eastern meadowlark densities were higher on hayfields than pastures for both years. The pastures on the refuge contain a large amount of shrub cover that eastern meadowlarks appeared to have avoided during the 1999 and 2000 seasons. Similar studies have found eastern meadowlarks prefer moderately tall grasslands with abundant litter cover, high proportion of grass, moderate to high forb density, and low coverage of woody vegetation (Rotenberry and Weins 1980, Bollinger 1995, Lanyon 1995, Hull 2000). Litter cover was higher in hayfields, which may have affected eastern 
meadowlark territory selection. Although significance was not detected, there was a higher percentage of forbs and grass and a lower percentage of woody cover found in hayfields.

There were differences in overall density, diversity, and richness between years. Grassland birds had a higher mean density in 1999, because of the flocks of bobolinks (> 100) and large numbers of red-winged blackbirds and eastern meadowlarks found on the survey plots that summer. These differences in bird abundance may be attributed to differences in weather conditions between the 2 years. West Virginia experienced a drought in 1999 and a normal amount of rainfall in 2000 (National Oceanic and Atmospheric Administration 2000). In Canaan Valley, May-August total precipitation showed a difference of $21.88 \mathrm{~cm}$ between 1999 and 2000. These precipitation events may have indirectly influenced grassland bird distributions and patterns in Canaan Valley and surrounding areas for both years. Variations in grassland bird densities have been linked with drought conditions even though drought effects appear to be short-lived with most species recovering within 1 year (O'Connor et al. 1999). While drought conditions may influence seasonal variations in grassland bird densities, it may ultimately be farmers' response to weather conditions that influence variations in densities in Canaan Valley. Most farmlands were mowed early in 1999 due to dry weather that allowed farmers access to their fields. The mowing on non-refuge land reduced available habitat, causing birds to concentrate on the refuge. Most farmers during the 2000 season, delayed mowing until middle-to-late July, because of continuous rainfall and unsuitable field conditions, thus providing additional habitat for birds during the 2000 season. While differences in average rainfall may influence farmer response, it is unlikely that 
differences in climatic conditions directly altered the grassland bird populations on the refuge.

Climatic factors, differential winter survival, or man-caused effects are probably not as important as the effects should be the same on each site (Whitmore 1979). However, conditions are not similar between public and private land in the Canaan Valley and contribute to variability in grassland bird populations. Increases in rainfall events may not alter grassland bird density, diversity, or species richness but it may affect nesting success and land management techniques. Flooding during prolonged periods of rainfall led to nest loss of some grassland bird species (Wray et al. 1982). Even though fields in Canaan Valley were periodically water saturated, flooding did not contribute directly to nest loss.

Differences were detected for grassland bird density, diversity, and richness among months with August having a reduction in density, diversity, and richness. Fewer birds were recorded during bird counts in August because most grassland birds had formed flocks or had abandoned their territories and were at sites that provided optimal foraging conditions for fledglings and upcoming fall migration. Although, most species were found in aggregations either in different parts of the valley or adjacent to transects during weekly surveys. Bobolinks, which are among the first to leave the valley, began flocking in middle to late July prior to molting. Savannah sparrows, which may tend nests through August, are among the last species to leave the valley.

The BBS data indicates that both eastern meadowlarks and savannah sparrows are declining nationally, regionally, and within West Virginia (Sauer et al. 2000). Canaan Valley NWR provides important habitat for grassland species in West Virginia because 
grassland habitat in West Virginia is limited to old or active farmlands and reclaimed strip mine habitats (Whitmore and Hall 1978). recommended managing reclaimed strip mine habitats for grassland bird communities in West Virginia because of limited habitat (Wray 1979). As small farming became less feasible fields were abandoned and succession changed the structural characteristics of the vegetation (Whitmore and Hall 1978). Prior to mine reclamation, grasshopper sparrows and vesper sparrows were declining in their ranges (Whitmore and Hall 1978). West Virginia lies in the southernmost range for these 2 species (Bucklew and Hall 1994), which may influence declining trends because their populations may fluctuate from year to year depending on their ability to find isolated grassland habitats in West Virginia. As these 2 species continue to decline idle and active agricultural fields and reclaimed mine sites if managed correctly in West Virginia may provide essential habitats for declining grassland species. The grassland portion of the refuge with active management will provide necessary habitat for grassland birds in West Virginia.

\section{Management Implications}

While some grassland species (i.e., savannah sparrows) may have responded negatively to the mowed treatment because of its reduction in litter depth and standing dead vegetation, active management of the grasslands on the Canaan Valley NWR is important. Site quality (area and vegetation characteristics) affected the number or kind of species present on the refuge. On small areas many edge species were found on areas dominated by shrubs, whereas bobolinks and eastern meadowlarks, target grassland species, were absent. Additionally, because these areas were previously farmlands many remnant fencelines, hedgerows, windbreaks, lanes, and trails exist. The removal of most 
of these structures would provide large, contiguous portions of grasslands that might attract those species that are area dependent (i.e., grasshopper sparrows, Henslow sparrows, and northern harriers). However, leaving a small percentage $(<5 \%)$ of woody cover on idle grassland sites would provide song perches for grassland songbirds. Additionally, leaving fence posts along the periphery of grasslands would provide additional song perches these species.

Grassland sites need to be large enough to support grassland populations. Vickery et al. (1994) suggests that grassland sites need to be $>50$ ha, preferably about 200 ha. Gore (1999) suggests field sizes should be > 100 ha. Whitmore (1980) suggests field sizes in West Virginia should be $>40$ ha. On the refuge, the sites with the greatest number of target species individuals were not necessarily the largest sites ( 28 - $93 \mathrm{ha}$ ). Grassland species appeared to be responding to the vegetative structure and vertical diversity found on these sites rather than field size, which is similar to Bollinger's (1995) findings. Although, bobolinks, eastern meadowlarks, and savannah sparrows do not necessarily need areas greater than 100 ha, other species such as grasshopper sparrows, found during 2000 on the 93 ha site, do require larger areas (Jones and Vickery 1997). A combination of mowing, grazing, and prescribed burning should be implemented to provide quality habitat by setting back succession for grassland species. These management techniques are necessary to prevent woody encroachment in habitat fragments and may reduce predation on ground nests (Burger et al. 1994). Herkert et al. (1996) found that providing a mosaic of mowed/unmowed, grazed/ungrazed, or burned/unburned habitats provides a full range of grassland bird habitat requirements, and accounts for the different responses grassland species have to management 
techniques. Mowing may be the most feasible option because it eliminates the need for coordinating with farmers for livestock grazing and unpredictable weather for prescribed burning. Sample and Hoffman (1989) found mowing can be used to control woody vegetation, lower vegetative height, and reduce litter build-up (if cuttings are harvested). While some species like eastern meadowlarks and savannah sparrows prefer developed litter layers, mowing or another management technique needs to be implemented before the litter layer becomes too dense and is unsuitable for nest site selection. Mowing should be conducted on a rotational basis leaving fields or portions of fields idle for 1-2 growing seasons. Reproductive success of bobolinks, savannah sparrows, and eastern meadowlarks improves if fields are mowed after July 15 (Jones and Vickery 1997). On the refuge mowing should be conducted in middle to late August to avoid destroying nests of double of triple brooding species.

While grassland areas on the refuge range from 10-92 ha, the largest grasslands are not necessarily providing adequate habitat for grassland bird species. The Hertz tract is dominated by scrub-shrub habitat (i.e., St. John's wort, narrow-leaved meadowsweet, blueberry [Vaccinium spp.]) and is supporting edge species rather than strict grassland bird nesting species. Eastern meadowlarks and bobolinks were not found on the Hertz tract during the summers of 1999 and 2000. The Hertz tract should not be considered for further grassland management due to inadequate habitat characteristics and permanently moist field conditions. Additionally, the Cortland tract should be excluded from grassland management plans due to its size and shape. The Cortland (> 16 ha) is a narrow strip of grassland bordered on all sides by either roads, small lanes, or forest 
edges. Birds found on this tract were predominantly edge-species and few grassland bird species were found at this site.

Tracts of land that should be included in a grassland management plan are: Beall, Cooper, Freeland, Harper, Reichell, and Thompson tracts. Management of these sites will vary depending on field conditions. The Freeland, Reichell, and Thompson tracts are water saturated throughout the year and would not be suitable for prescribed burns. These sites may benefit from rotational mowing and/or grazing. The Beall, Cooper, and Harper tracts are found in a drier portion of the Valley and would provide suitable sites for prescribed burning. These sites also should incorporate mowing and/or grazing as a management alternative. Typically mowing/grazing is conducted in blocks and each block may be mowed every 2-5 years depending on the management objectives. Hawthorne (Crategus spp.) should be removed from the Beall, Cooper, Harper, and Thompson tracts to reduce effects of woody edge on grassland species. Woody vegetative cover found on in the interior of grassland tracts may negatively affect grassland birds by increasing predator densities and possibly creating travel or foraging lanes for predators (Warren and Ryan 1999). If woody cover is reduced within the interior of grassland tracts, it may positively affect grassland bird productivity.

\section{Additional Research}

Further research should be conducted on the Canaan Valley grasslands to determine the effect surrounding active farmland management have on the density, diversity, and richness of species found on the refuge. If area farms are managed during grassland bird breeding seasons, this may directly affect the grassland birds on the refuge and force them to either forage or nest on neighboring farmlands. Additionally, 
understanding grassland bird responses to active farmland management may aid the refuge in developing a more comprehensive management plan and provide the refuge overall grassland bird productivity data for the entire valley.

Further research also should be conducted on the conversion of some cool-season grass fields to warm-season grass fields. This would provide information on the value of warm season versus cool season grasses to grassland bird productivity on the refuge.

\section{LITERATURE CITED}

American Ornithologists' Union. 1998. Check-list of North American birds. Seventh edition. American Ornithologists' Union, Washington D. C., USA.

Askins, R. A. 1997. History of the grasslands in the Northeastern United States: Implications for bird conservation. Pages 119-136 in Vickery, P. D., and P. W. Dunwiddie, editors. Grasslands of Northeastern North America: Ecology and conservation of native and agricultural landscapes. Massachusetts Audubon Society, Massachusetts.

Best, L. B., H. Campa, III, K. E. Kemp, R. J. Robel, M. R. Ryan, J. A. Savidge, H. P. Weeks, Jr., and S. R. Winterstein. 1997. Bird abundance and nesting in CRP fields and cropland in the Midwest: A regional approach. Wildlife Society Bulletin 25:864-877.

Bollinger, E. K. 1995. Successional changes and habitat selection in hayfield bird communities. Auk 112:720-730.

Bollinger, E. K., and T. A. Gavin. 1989. The effects of site quality on breeding-site fidelity in bobolinks. Auk 106:584-594. 
Bollinger, E. K., P. B. Bollinger, and T. A. Gavin. 1990. Effects of hay-cropping on eastern populations of the bobolink. Wildlife Society Bulletin 18:142-150.

Bollinger, E. K., and T. A. Gavin. 1992. Eastern bobolink populations: Ecology and conservation in an agricultural landscape. Pages 497-506 in J. M. Hagan III and D. W. Johnson, editors. Ecology and conservation of neotropical landbirds. Smithsonian Institution, Washington D. C., USA.

Buckelew, A. R., Jr., and G. A. Hall. 1994. The West Virginia breeding bird atlas. University of Pittsburgh Press, Pittsburgh, Pennsylvania, USA.

Burger, L. D., L. W. Burger, and J. Faaborg. 1994. Effects of prairie fragmentation on predation on artificial nests. Journal of Wildlife Management 58:249-254.

Cody, R. P., and J. K. Smith. 1991. Applied statistics and the SAS programming language. Third edition. Elsevier Scientific Publications, New York, New York, USA.

Conover, W. J., and R. L. Iman. 1981. Rank transformations as a bridge between parametric and nonparametric statistics. American Statistician 35:124-129.

Dale, B. C. 1984. Birds of grazed and ungrazed grasslands in Saskatchewan. Blue Jay 42:102-105.

Daubenmire, R. F. 1959. A canopy coverage method of vegetation analysis. Northwest Science 35:43-64.

Delisle, J. M., and J. A. Savidge. 1997. Avian use and vegetation characteristics of Conservation Reserve Program fields. Journal of Wildlife Management 61:318325. 
Farris, A. L., and J. H. Cole. 1981. Strategies and goals for wildlife habitat restoration on agricultural lands. Transactions of North American Wildlife and Natural Resource Conference 46:130-136.

Fortney, R. H. 1993. Canaan Valley - An area of special interest within the upland forest region. Pages 47-65 in S. L. Stephenson, editor. Upland forests of West Virginia, McClain Print Company, Parsons, West Virginia, USA.

Franzreb, K. E. 1981. The determination of avian densities using the variable-strip and fixed-width transect surveying methods. Studies in Avian Biology 6:139-145.

Frawley, B. J., and L. B. Best. 1991. Effects of mowing on breeding bird abundance and species composition in alfalfa fields. Wilson Society Bulletin 19:135-142.

Gates, J. E. 1995. Point count modifications and breeding bird abundance in central Appalachian forests. Pages 135-144 in Ralph, C. J., J. R. Sauer, and S. Droege, editors. Monitoring bird populations by point counts. U.S. Forest Service, General Technical Report PSW-GTR-149.

Gore, L. B. 1999. Habitat preference and management strategies for grassland birds on the Wallkill River National Wildlife Refuge, New Jersey. Thesis, University of Massachusetts, Amherst, Massachusetts, U. S. A.

Graber, R. R., and J. W. Graber. 1963. A comparative study of bird populations in Illinois, 1906-1909, and 1956-1958. Illinois Natural History Bulletin 28:383-519.

Herkert, J. R. 1994. The effects of habitat fragmentation on midwestern grassland bird communities. Ecological Applications 4:461-471.

Herkert, J. R., D. W. Sample, and R. E. Warner. 1996. Management of Midwestern grassland landscapes for the conservation of migratory birds. Pages 89-116 in F. 
R. Thompson, III, editor. Management of Midwestern landscapes for the conservation of migratory birds. U. S. Forest Service General Commissioners 32:234-241.

Hull, S. D. 2000. Effects of management practices on grassland birds: eastern meadowlark. Northern Prairie Wildlife Research Center, Jamestown, North Dakota, USA.

Jones, A. and P. Vickery. 1997. Conserving grassland birds: Managing agricultural lands including hayfields, crop fields, and pastures for grassland birds. Grassland Conservation Program, Center for Biological Conservation, Massachusetts Audubon Society, Lincoln, Massachusetts, USA.

Kantrud, H. A., and K. F. Higgins. 1992. Nest and nest site characteristics of some ground-nesting, non-passerine birds of northern grasslands. Prairie Naturalist 24:67-83.

Knopf, F. L. 1994. Avian assemblages on altered grasslands. Studies in Avian Biology 15:247-257.

Lanyon, W. E. 1995. Eastern meadowlark (Sturnella magna). In Birds of North America, No. 160 (A. Poole and F. Gill, eds.). The Academy of Natural Sciences, Philadelphis, PA, and The American Ornithologists' Union, Washington, D. C., USA.

Madden, E. M., R. K. Murphy, and L. Murray. 2000. Models for guiding management of prairie bird habitat in northwestern North Dakota. American Midland Naturalist 144:377-392. 
Martin, S. G., and T. A. Gavin. 1995. Bobolink (Dolichonyz oryzivorus). In The Birds of North America, No. 176. (A. Poole and F. Gill, eds.). The Academy of Natural Sciences, Philadelphia, PA, and The American Ornithologists' Union, Washington, D. C., USA.

National Oceanic and Atmospheric Administration. 1999. National Climatological Data: Canaan Valley, West Virginia. U. S. Department of Commerce, Washington, D. C., USA.

National Oceanic and Atmospheric Administration. 2000. National Climatological Data: Canaan Valley, West Virginia. U. S. Department of Commerce, Washington, D. C., USA.

Norment, C. J., C. D. Ardizzone, and K. Hartman. 1999. Habitat relations and breeding biology of grassland birds in New York. Studies in Avian Biology 19:112-121.

O’Connor, R. J., M. T. Jones, R. B. Boone, and T. B. Lauber. 1999. Linking contintental climate, land use, and land patterns with grassland bird distribution across the conterminous United States. Studies in Avian Biology 19:45-59.

Peterjohn, B. G., and J. R. Sauer. 1999. Population status of North American grassland birds from the North American Breeding Bird Survey, 1966-1996. Studies in Avian Biology 19:27-44.

Robel, R. J., J. N. Briggs, A. D. Dayton, and L. C. Hulbert. 1970. Relationships between visual obstruction measurements and weight of grassland vegetation. Journal of Range Management 23:295-298. 
Rotenberry, J. T., and J. A. Weins. 1980. Habitat structure, patchiness, and avian communities in North American steppe vegetation: a multivariate analysis. Ecology 61:1228-1250.

Sample, D. W., and R. M. Hoffman. 1989. Birds of dry-mesic and dry prairies in Wisconsin. Passenger Pigeon 51:195-208.

Sauer, J. R., J. E. Hines, I. Thomas, J. Fallon, and G. Gough. 2000. The North American Breeding Bird Survey, results and analysis 1966-1999. Version 98.1. USGS Patuxent Wildlife Research Center, Laurel, Maryland, USA.

Shannon, C. E. 1948. A mathematical theory of communication. Bell System Technical Journal 27:379-423.

Strausbaugh, P. D., and E. L. Core. 1977. Flora of West Virginia. Second Edition. Seneca Books, Morgantown, West Virginia, USA.

Swanson, D. A. 1998. Effects of management practices on grassland birds: savannah sparrow. Northern Prairie Wildlife Research Center, Jamestown, North Dakota, USA.

Thornthwaite, C. W. 1948. An approach toward a rational classification of climate. Geographical Review. The American Geological Society of New York, pages 5594.

United States Fish and Wildlife Service. 1979. Final environmental impact statement acquisition of lands for the Canaan Valley National Wildlife Refuge West Virginia. United States Department of the Interior.

Vickery, P. D. 1996. Grasshopper sparrow (Ammodramus savannarum). Birds of North America 239:1-23. 
Vickery, P. D., M. L. Hunter, Jr., and S. M. Melvin. 1994. Effects of habitat area on the distribution of grassland birds in Maine. Conservation Biology 8:1087-1097.

Vickery, P. D., P. L. Tubaro, J. M. Cardoso da Silva, B. G. Peterjohn, J. R. Herkert, and R. B. Cavalcanti. 1999. Conservation of grassland birds in the western hemisphere. Studies in Avian Biology 19:2-26.

Vogelmann, H. W. 1978. Evaluation of the Canaan Valley - Cabin mountain wetland, Tucker County, West Virginia. Department of the Army, Corps of Engineers, Davis, West Virginia, USA.

Warren, K. A., and M. R. Ryan. 1999. Do internal fire lanes affect nest depredation rates in prairies? The Prairie Naturalist 31:215-220.

Wheelwright, N. T., and J. D. Rising. 1993. Savannah sparrow (Passerculus sandwichensis). In The Birds of North America, No. 45 (A. Poole and F. Gill, eds.). The Academy of Natural Sciences, Philadelphia, PA, and The American Ornithologists' Union, Washington, D. C., USA.

Whitmore, R. C. 1979. Short-term change in vegetation structure and its effect on grasshopper sparrows in West Virginia. Auk 96:621-625.

Whitmore, R. C. 1980. Reclaimed surface mines as avian habitat islands in the eastern forest. American Birds 34:13-14.

Whitmore, R. C., and G. A. Hall. 1978. The response of passerine species to a new resource: reclaimed surface mines in West Virginia. American Birds 32:6-9.

Wray, T., II. 1979. Breeding biology and reproductive success of three sparrow species on reclaimed surface mines in West Virginia. Thesis, West Virginia UniversityMorgantown, West Virginia, USA. 
Wray, T., II, P. B. Wackenhut, and R. C. Whitmore. 1978. The reproductive biology of passerine birds breeding on reclaimed surface mines in northern West Virginia. Pages 333-344 in D. E. Samuel, J. R. Stauffer, C. H. Hocutt, and W. T. Mason, Jr., editors. Proceeding of Symposium on Surface mining and fish/wildlife needs in the eastern United States. USFWS FWS/OBS-78/81.

Wray, T., II., K. A. Strait, and R. C. Whitmore. 1982. Reproductive success of grassland sparrows on a reclaimed surface mine in West Virginia. Auk 99:157-164.

Wells, J. V., and K. V. Rosenberg. 1999. Grassland bird conservation in northeastern North America. Studies in Avian Biology 19:72-80.

Zar, J. H. 1999. Biostatistical analysis. Fourth edition. Prentice Hall, Upper Saddle River, New Jersey, USA. 
Table 1. Breeding Bird Survey (BBS) grassland bird population trends (1966-1998) for species found in West Virginia on the Canaan Valley National Wildlife Refuge, Tucker County (Sauer et al. 2000).

\begin{tabular}{lccc}
\hline Species & Total Trend $^{\mathrm{a}}$ & ${\text { FWS Region5 }(\mathrm{NE})^{\mathrm{b}}}^{\mathrm{b}}$ & $\mathrm{WV}^{\mathrm{c}}$ \\
\hline Savannah sparrow & -0.50 & -2.28 & -6.84 \\
Bobolink & -1.58 & +0.15 & +2.11 \\
Eastern meadowlark & -2.74 & -4.68 & -3.40 \\
Red-winged blackbird & -1.04 & -2.62 & -2.58 \\
Vesper sparrow & -0.76 & -5.29 & -15.05 \\
Grasshopper sparrow & -3.38 & -4.28 & -12.00 \\
Northern harrier & -0.63 & -3.11 & -- \\
\hline
\end{tabular}

${ }^{a}$ Survey-wide grassland bird species group population change.

${ }^{\mathrm{b}}$ Grassland bird population change data for USFWS refuges in Connecticut, Delaware, Maryland, Massachusetts, New Hampshire, New Jersey, New York, Pennsylvania, Rhode Island, Vermont, Virginia, and West Virginia.

${ }^{c}$ Population trend data for grassland birds found on the Canaan Valley NWR for 1999 and 2000. 
Table 2. Breeding grassland bird density (number of birds/ha), diversity, and richness between mowed and unmowed treatments on the Canaan Valley National Wildlife Refuge, West Virginia, May-August 2000 ${ }^{\mathrm{a}}$.

\begin{tabular}{|c|c|c|c|c|}
\hline \multirow[b]{2}{*}{ Species } & \multicolumn{2}{|c|}{ Mowed } & \multicolumn{2}{|c|}{ Unmowed } \\
\hline & $\bar{x}$ & $\mathrm{SE}$ & $\bar{x}$ & SE \\
\hline Total birds & 1.38 & 0.18 & 1.50 & 0.32 \\
\hline Bobolink & $0.29 a$ & 0.09 & $0.67 \mathrm{a}$ & 0.32 \\
\hline $\begin{array}{l}\text { Eastern } \\
\text { meadowlark }\end{array}$ & $0.07 \mathrm{a}$ & 0.02 & $0.05 \mathrm{a}$ & 0.01 \\
\hline $\begin{array}{l}\text { Savannah } \\
\text { sparrow }\end{array}$ & $0.17 \mathrm{a}$ & 0.05 & $0.35 b$ & 0.06 \\
\hline Diversity & 0.57 & 0.02 & 0.41 & 0.02 \\
\hline Richness & $1.30 \mathrm{a}$ & 0.07 & $1.08 \mathrm{a}$ & 0.04 \\
\hline
\end{tabular}

${ }^{a}$ Mean pairs followed by the same letter are not different $(P>0.05)$ between mowed and unmowed treatments. Means without letters were not tested due to significant interactions. 
Table 3. Breeding grassland bird density (number of birds/ha), diversity, and richness between hayfields and pastures on the Canaan Valley National Wildlife Refuge, West Virginia, May-August 1999-2000ª

\begin{tabular}{|c|c|c|c|c|}
\hline \multirow[b]{2}{*}{ Species } & \multicolumn{2}{|c|}{ Hayfields } & \multicolumn{2}{|c|}{ Pastures } \\
\hline & $\bar{x}$ & $\mathrm{SE}$ & $\overline{\mathrm{x}}$ & SE \\
\hline Total birds & $3.62 \mathrm{a}$ & 1.01 & $6.13 \mathrm{a}$ & 2.57 \\
\hline Bobolink & $0.73 a$ & 0.42 & $2.00 \mathrm{a}$ & 1.00 \\
\hline $\begin{array}{l}\text { Eastern } \\
\text { meadowlark }\end{array}$ & $0.27 \mathrm{a}$ & 0.07 & $0.07 b$ & 0.04 \\
\hline $\begin{array}{l}\text { Savannah } \\
\text { sparrow }\end{array}$ & $0.38 \mathrm{a}$ & 0.06 & $0.27 \mathrm{a}$ & 0.07 \\
\hline Diversity & $0.32 \mathrm{a}$ & 0.04 & $0.41 \mathrm{a}$ & 0.06 \\
\hline Richness & $1.09 \mathrm{a}$ & 0.15 & $1.50 \mathrm{a}$ & 0.25 \\
\hline
\end{tabular}

${ }^{a}$ Means followed by the same letter are not different $(P>0.05)$ between mowed and unmowed treatments. Means without letters were not tested due to significant interactions. 
Table 4. Vegetative characteristics for mowed and unmowed treatments on the Canaan

Valley National Wildlife Refuge, Tucker County, West Virginia, June-August 2000.

\begin{tabular}{|c|c|c|c|c|c|}
\hline \multirow[b]{2}{*}{ Variable } & & \multicolumn{2}{|c|}{ Mowed } & \multicolumn{2}{|c|}{ Unmowed } \\
\hline & & $\bar{x}$ & $\mathrm{SE}$ & $\bar{x}$ & $\mathrm{SE}$ \\
\hline \multicolumn{6}{|l|}{ Ground Cover (\%) } \\
\hline & Canopy & 79.20 & 3.31 & 73.21 & 3.27 \\
\hline & Litter & 17.81 & 3.14 & 20.19 & 3.30 \\
\hline & Bare Ground & 3.10 & 1.39 & 6.68 & 2.37 \\
\hline \multicolumn{6}{|l|}{ Growth State $(\%)$} \\
\hline & Live & 77.28 & 3.16 & 66.01 & 4.83 \\
\hline & Dead & 1.20 & 0.38 & 3.09 & 0.61 \\
\hline \multicolumn{6}{|l|}{ Vegetative Cover $(\%)$} \\
\hline & Forbs & 37.92 & 2.02 & 35.94 & 2.60 \\
\hline & Grasses & 39.84 & 2.20 & 33.07 & 3.48 \\
\hline & Wood & 0.73 & 0.40 & 4.20 & 1.52 \\
\hline Vertical Density (cm) & & 18.43 & 2.65 & 22.65 & 2.76 \\
\hline Maximum Height (cm) & & 50.57 & 4.98 & 51.80 & 4.56 \\
\hline Litter Depth (cm) & & 1.73 & 0.16 & 2.67 & 0.20 \\
\hline
\end{tabular}


Table 5. Vegetative characteristics for hayfields and pastures on the Canaan Valley

National Wildlife Refuge, Tucker County, West Virginia, June-August 1999-2000.

\begin{tabular}{|c|c|c|c|c|c|}
\hline \multirow[b]{2}{*}{ Variable } & & \multicolumn{2}{|c|}{ Hayfields } & \multicolumn{2}{|c|}{ Pastures } \\
\hline & & $\bar{x}$ & $\mathrm{SE}$ & $\bar{x}$ & SE \\
\hline \multicolumn{6}{|l|}{ Ground Cover (\%) } \\
\hline & Canopy & 75.35 & 2.84 & 76.63 & 4.02 \\
\hline & Litter & 20.38 & 2.83 & 17.58 & 3.73 \\
\hline & Bare Ground & 4.30 & 1.33 & 5.96 & 2.81 \\
\hline \multicolumn{6}{|l|}{ Growth State $(\%)$} \\
\hline & Live & 71.97 & 2.49 & 70.13 & 6.31 \\
\hline & Dead & 2.83 & 0.56 & 1.52 & 0.56 \\
\hline \multicolumn{6}{|l|}{ Vegetative Cover $(\%)$} \\
\hline & Forbs & 34.21 & 1.94 & 39.40 & 4.30 \\
\hline & Grasses & 38.55 & 1.80 & 33.26 & 4.30 \\
\hline & Wood & 1.99 & 0.82 & 3.37 & 1.71 \\
\hline Vertical Density (cm) & & 18.14 & 2.20 & 23.83 & 3.24 \\
\hline Maximum Height (cm) & & 47.45 & 3.83 & 55.79 & 5.57 \\
\hline Litter Depth (cm) & & 2.53 & 0.23 & 1.90 & 0.16 \\
\hline
\end{tabular}




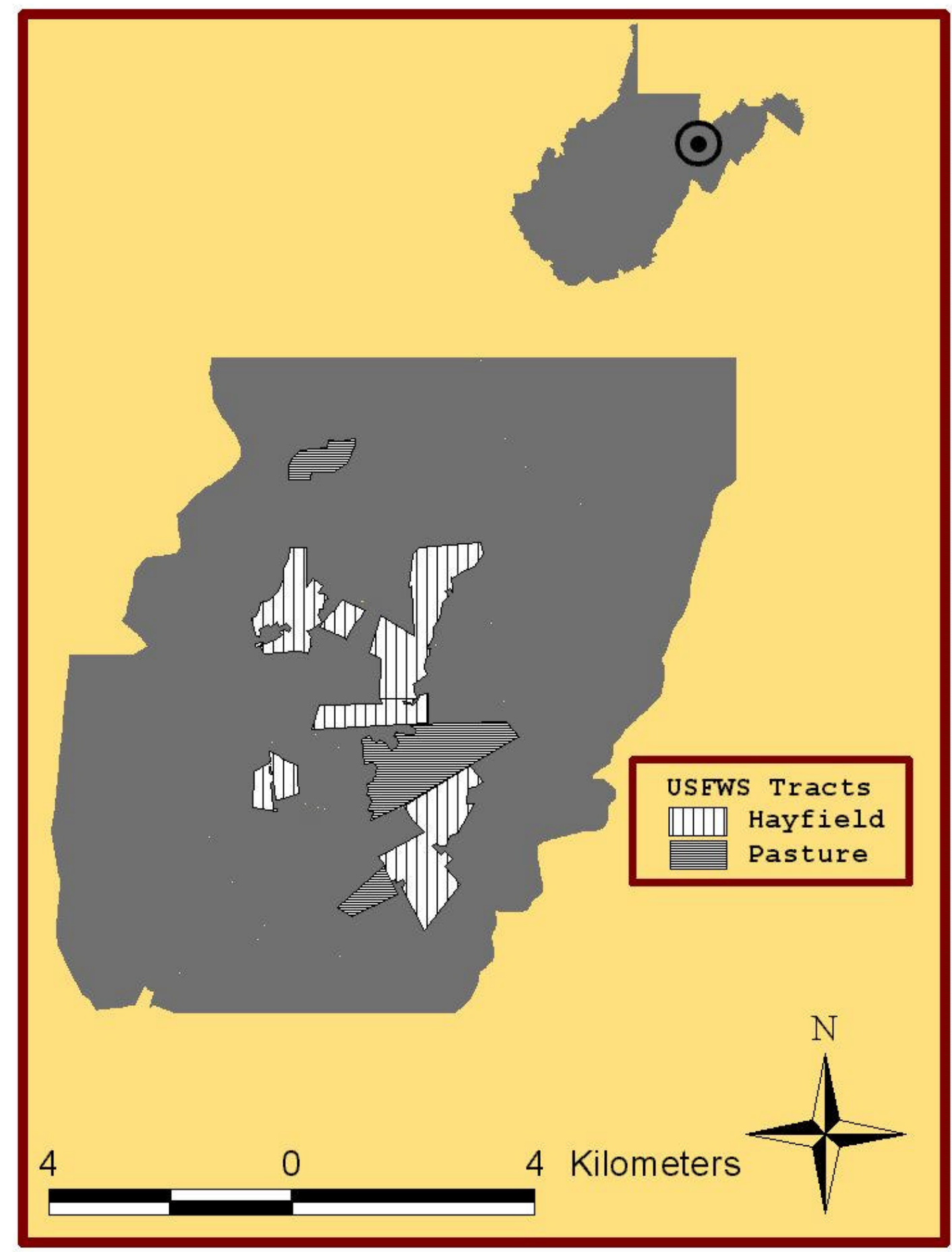

Figure 1. Canaan Valley National Wildlife Refuge grassland study sites in Tucker County, West Virginia for 1999 and 2000. 


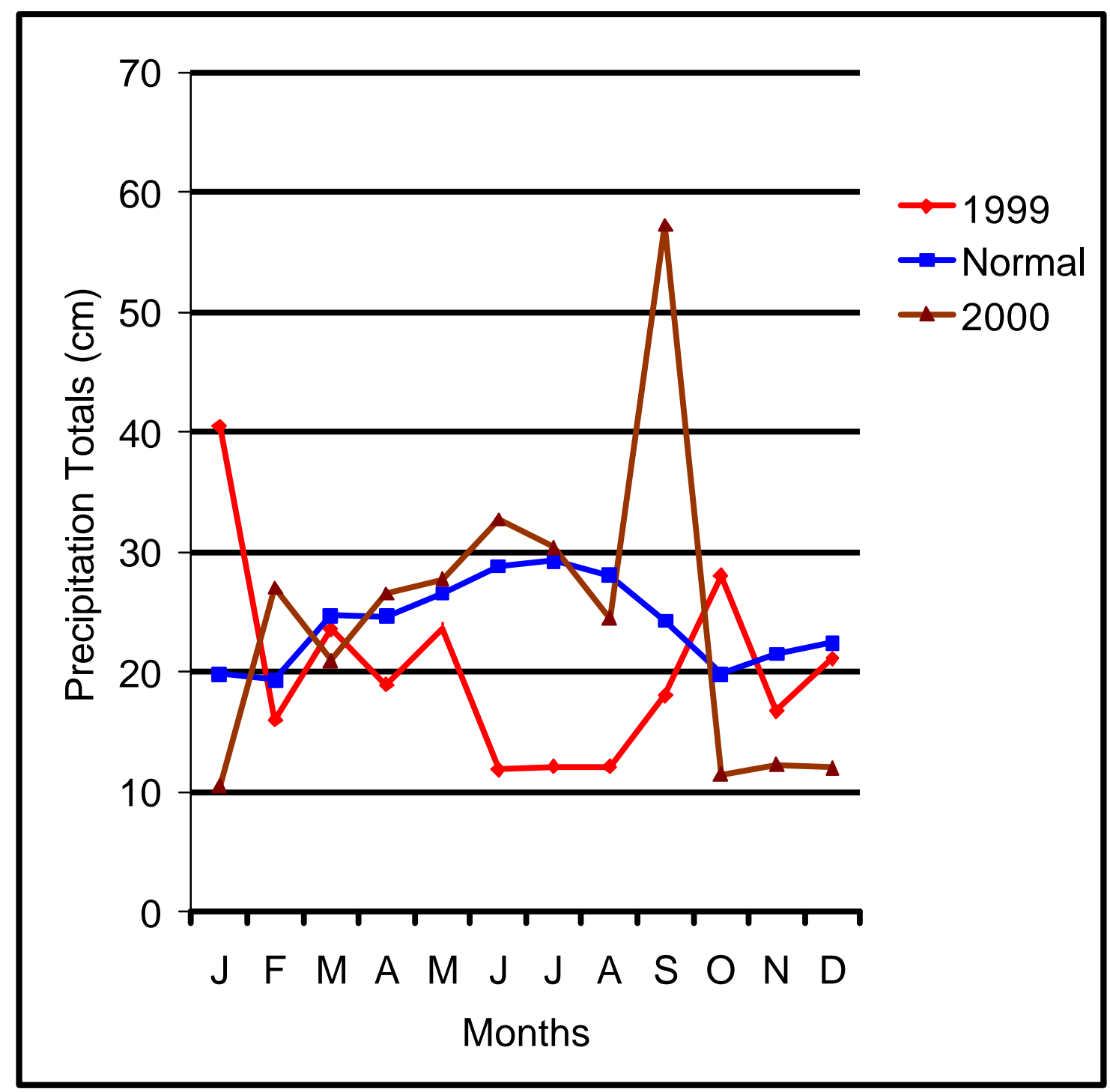

Figure 2. Monthly precipitation totals (cm) for 1999 and 2000, and normal monthly rainfall values for Canaan Valley, Tucker County, West Virginia 1999-2000. 


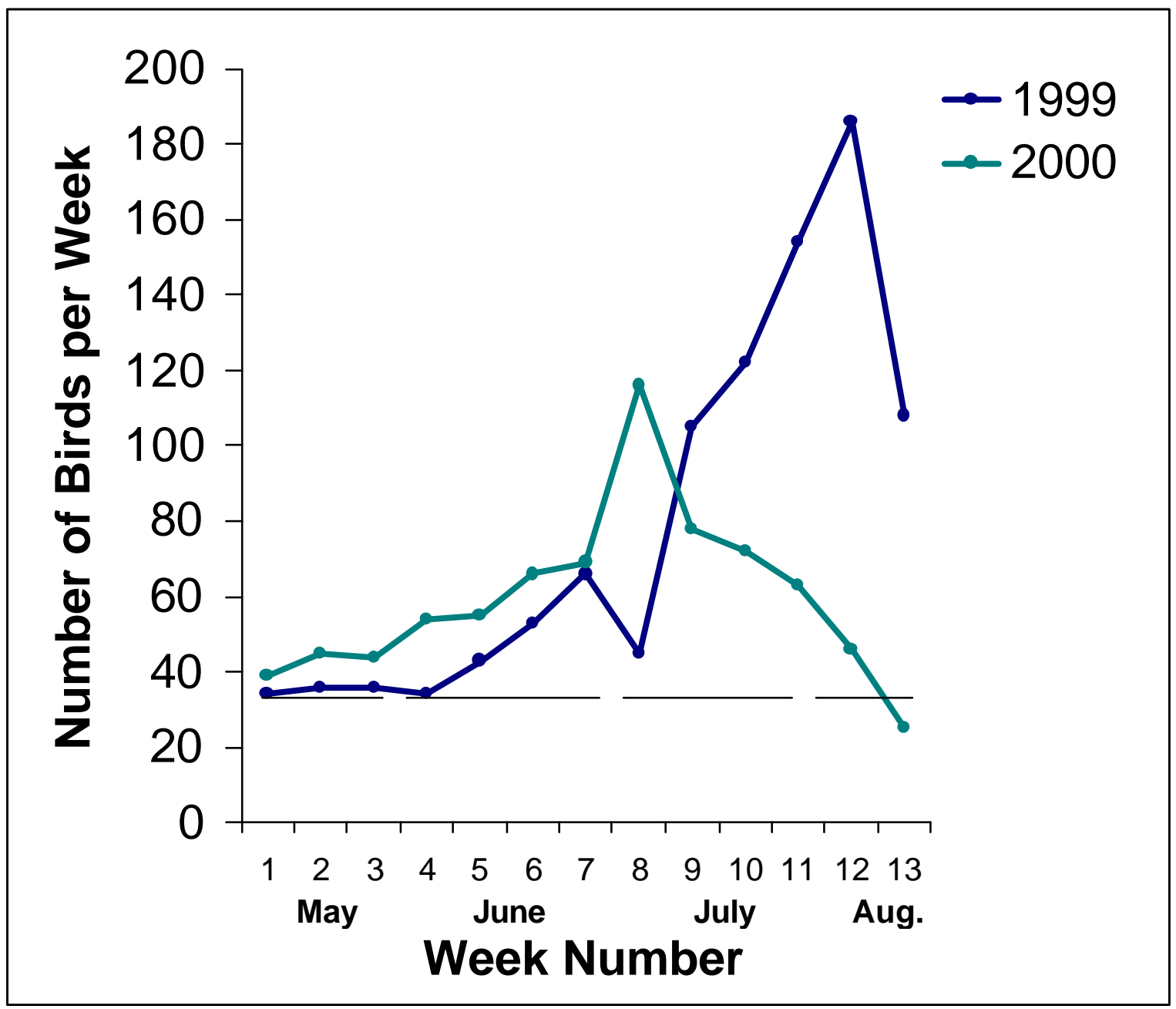

Figure 3. Total birds counted for weekly bird surveys on the Canaan Valley National Wildlife Refuge, Tucker County, West Virginia, May-August 1999-2000. Week 1 is the 2nd week in May and Week 13 is the 2nd week in August. 


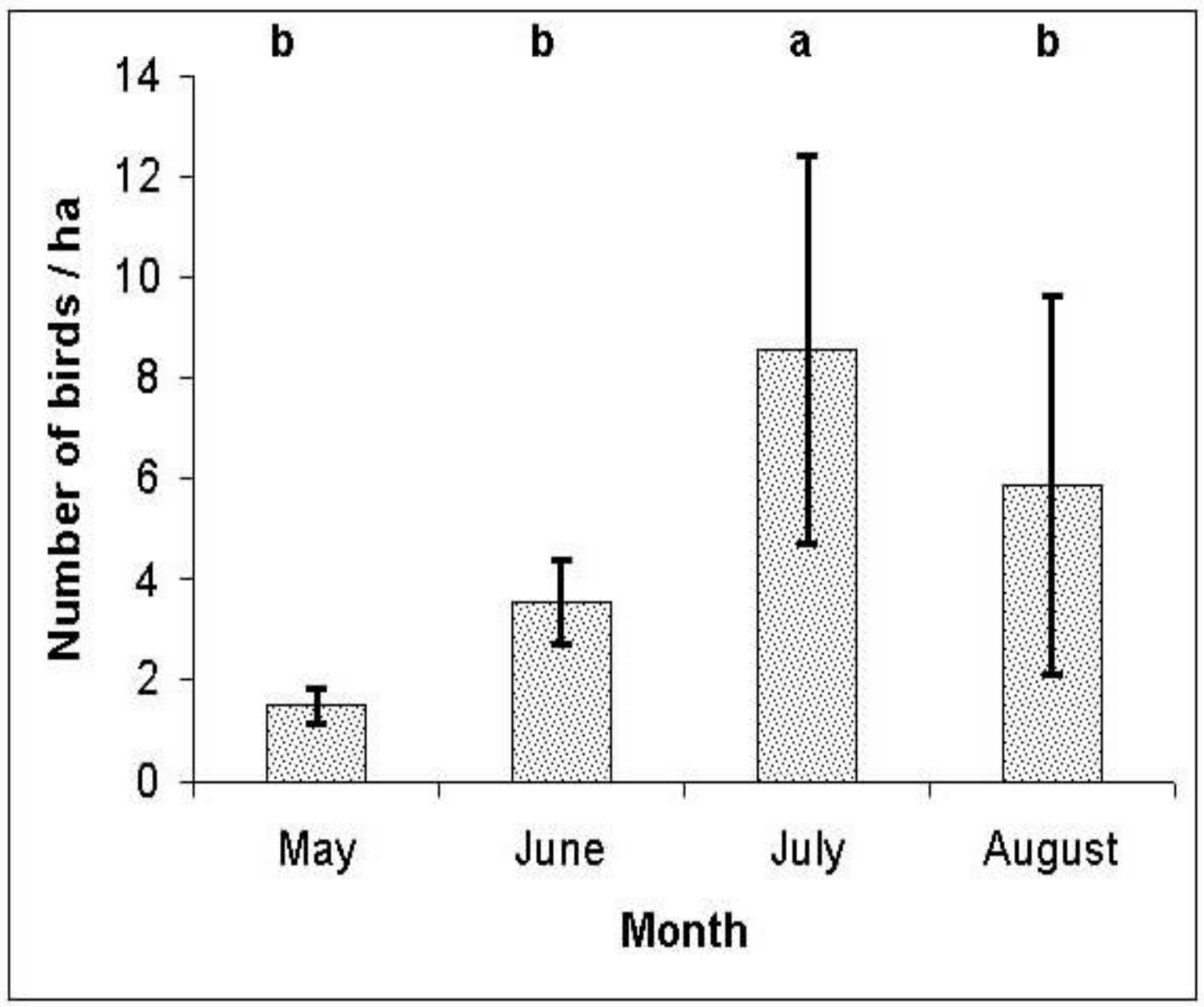

Figure 4. Breeding grassland bird density for all species combined among months on the Canaan Valley NWR, Tucker County, West Virginia, May-August 1999-2000. The same letter above bars indicate no difference $(P>0.05)$ among months. 


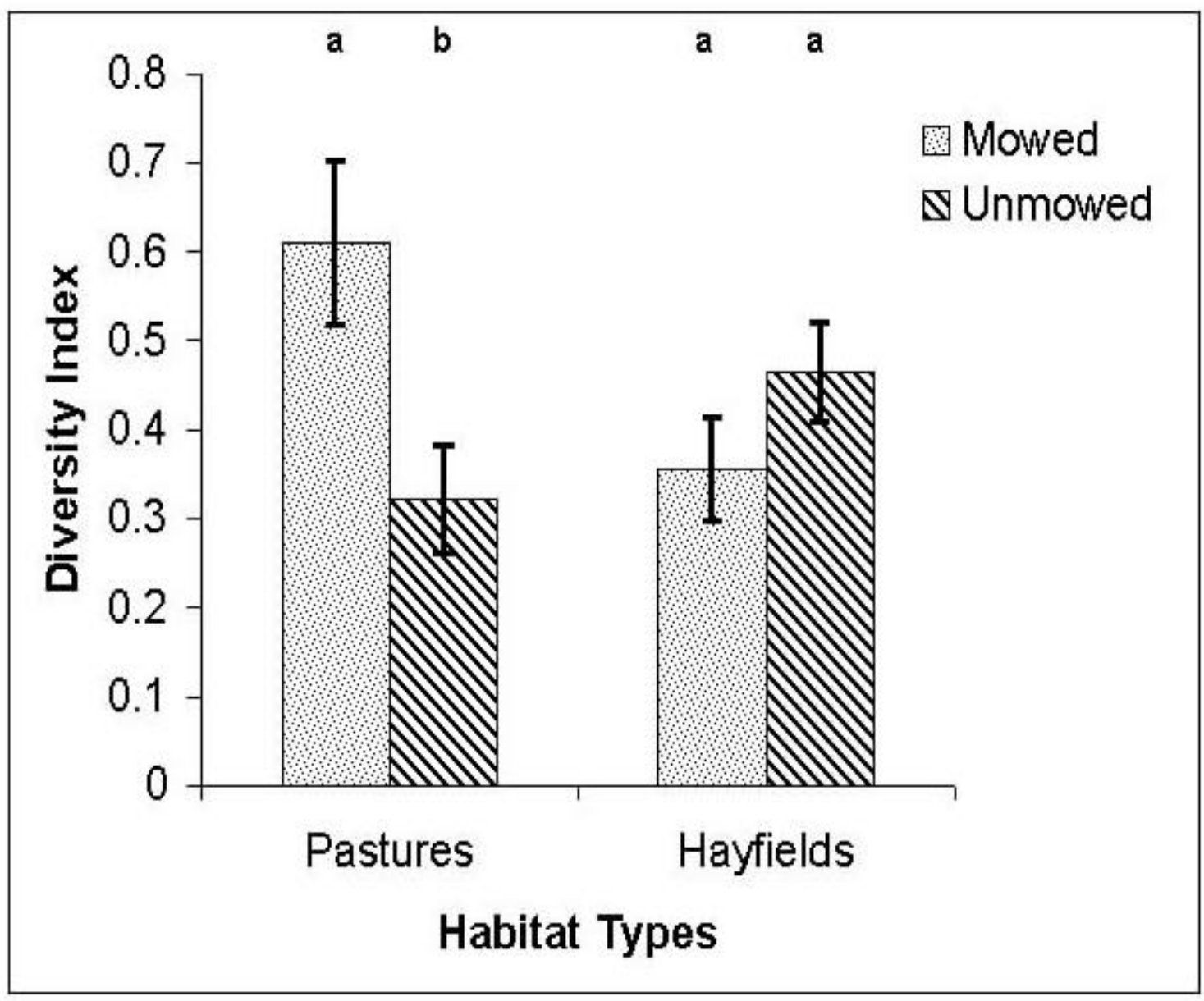

Figure 5. Breeding grassland bird diversity based on Shannon-Weiner diversity index (Zar 1999) between treatments within habitat types on the Canaan Valley NWR, Tucker County, West Virginia, May-August 2000. The same letter above bars indicates no difference $(P>0.05)$ between treatments within habitat types. 


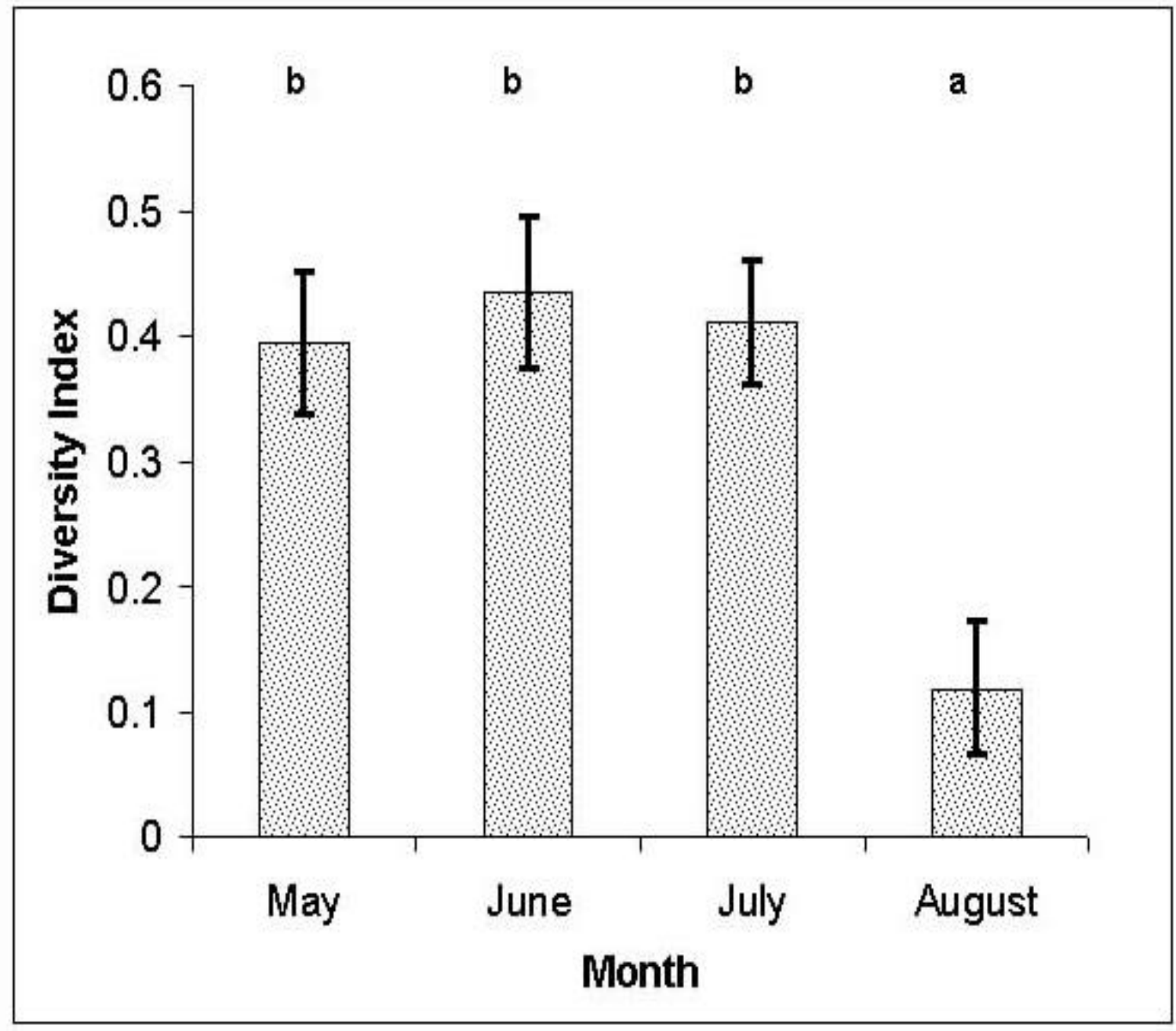

Figure 6. Breeding grassland bird diversity based on Shannon-Weiner diversity index (Zar 1999) among months on the Canaan Valley NWR, Tucker County, West Virginia, May-August 1999-2000. The same letter above bars indicates no difference $(P>0.05)$ among months. 


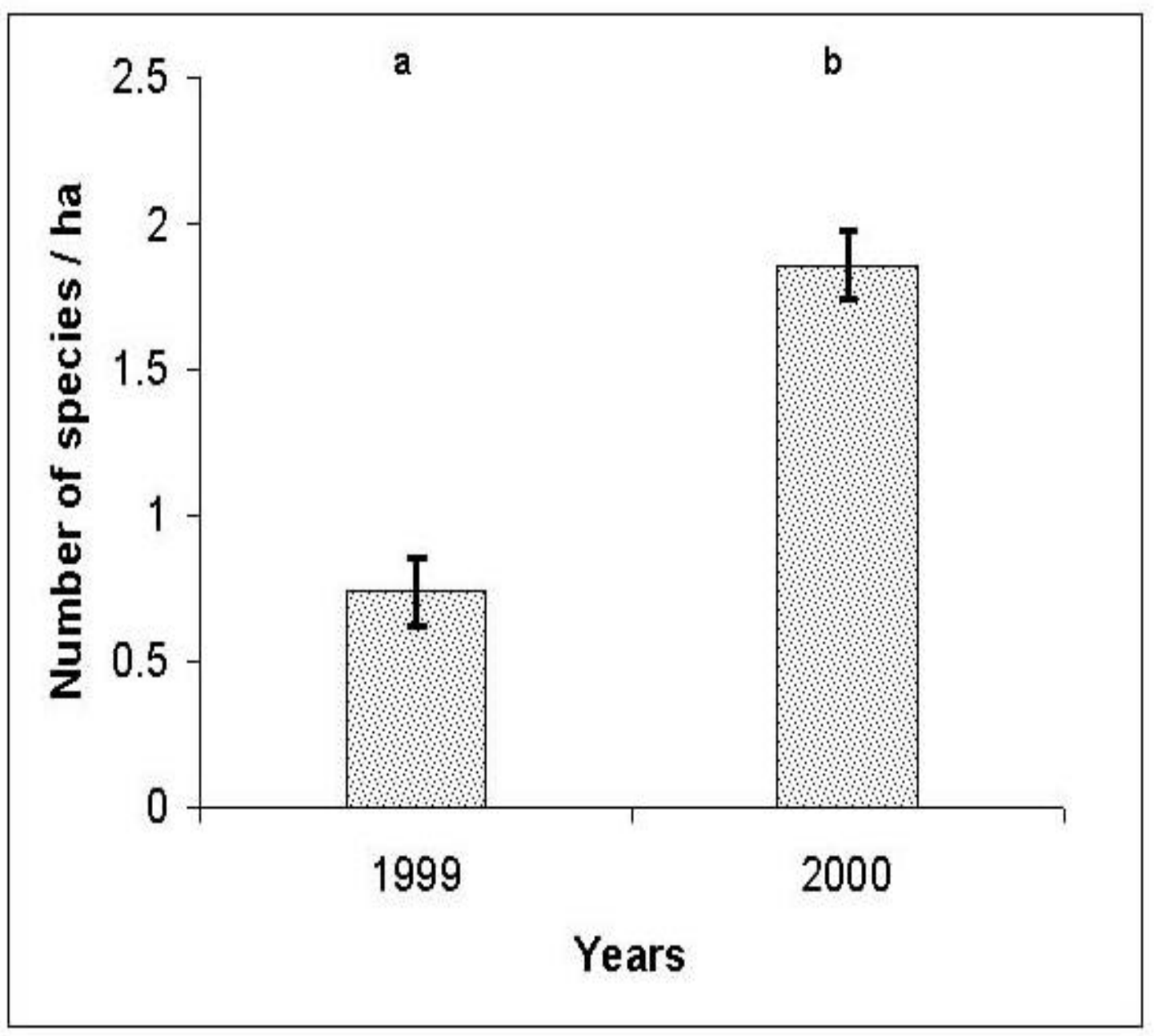

Figure 7. Breeding grassland bird richness between years on the Canaan Valley NWR, Tucker County, West Virginia, May-August 1999-2000. The same letter above bars indicates no difference $(P>0.05)$ between years. 


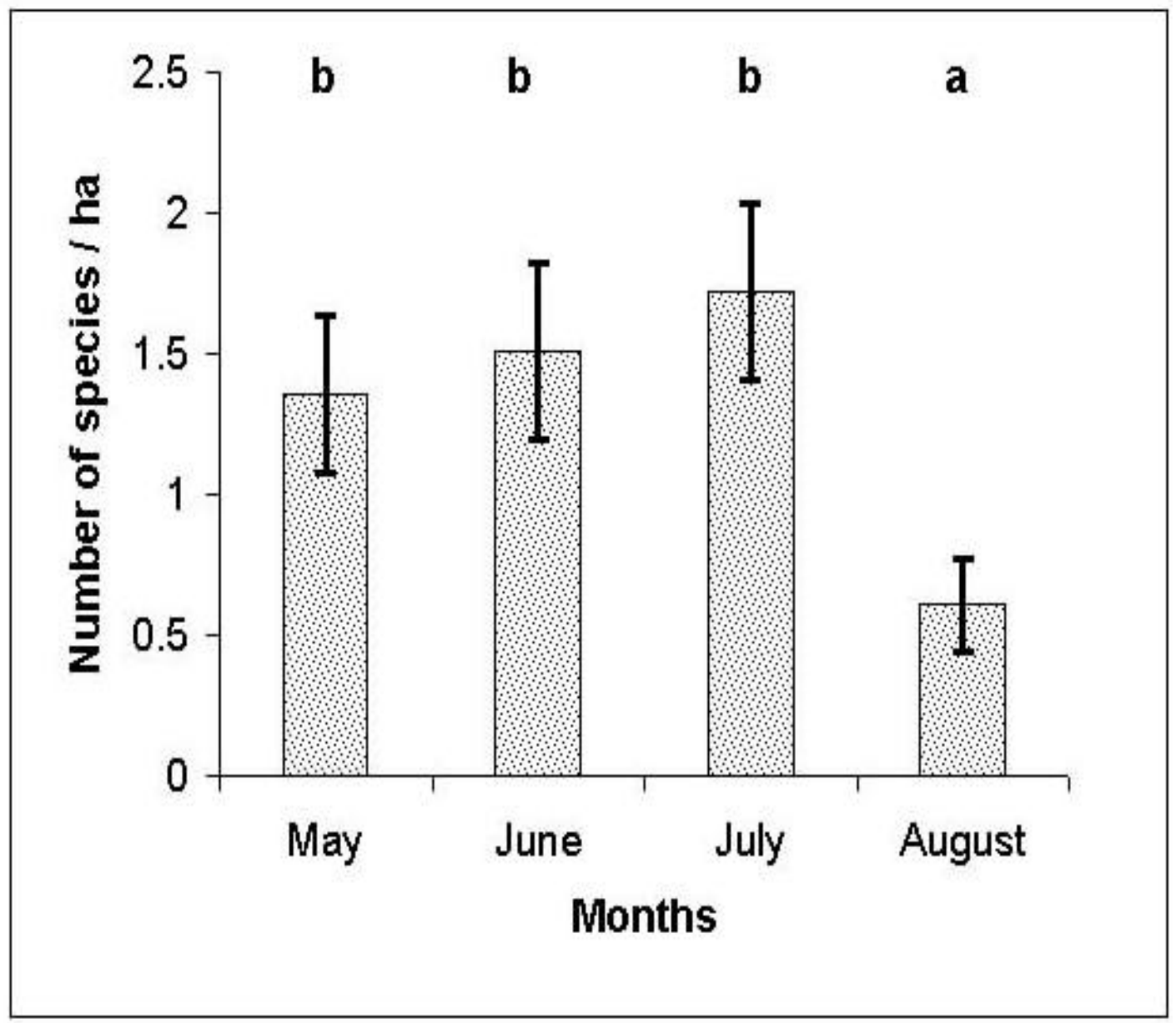

Figure 8. Breeding grassland bird richness by months on the Canaan Valley National Wildlife Refuge, Tucker County, West Virginia, May-August 1999-2000. The same letter above bars indicates no difference $(P>0.05)$ among months. 


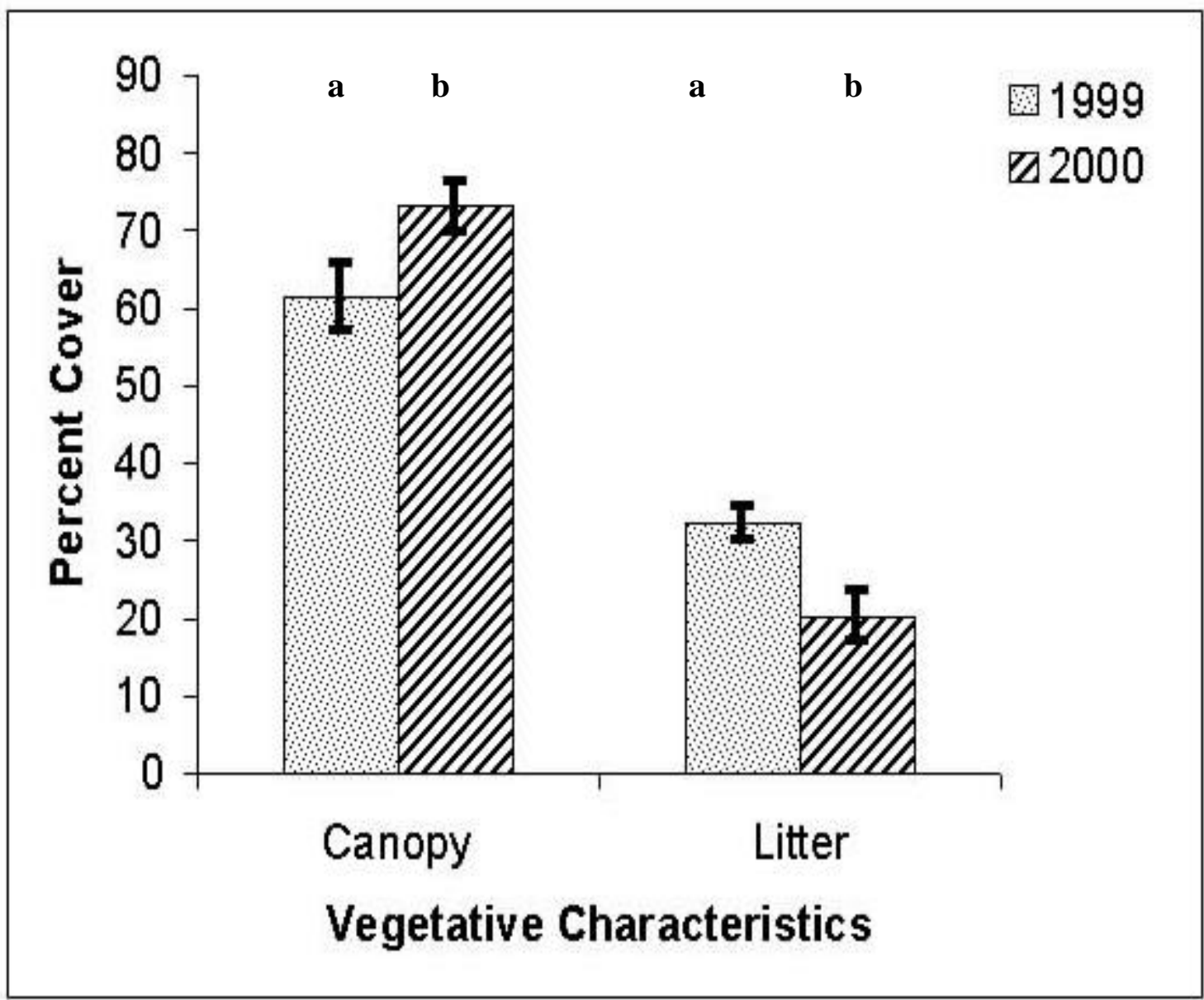

Figure 9. Comparison of percent canopy and percent litter between years on the Canaan Valley National Wildlife Refuge, Tucker County, WV 1999-2000. The same letter above bars indicates no difference $(P>0.05)$ between years. 


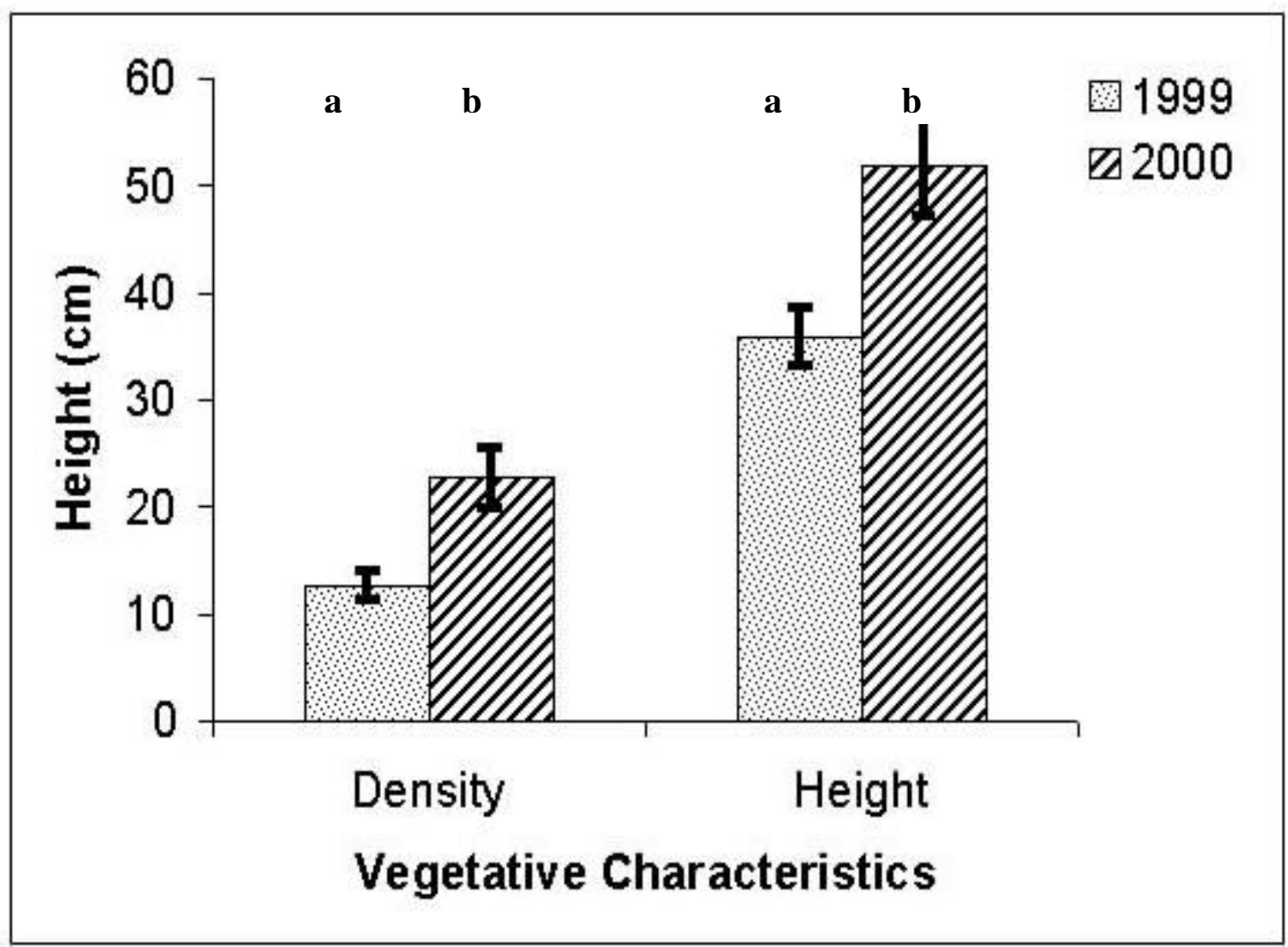

Figure 10. Comparison of vertical density $(\mathrm{cm})$ and maximum height $(\mathrm{cm})$ between years on the Canaan Valley National Wildlife Refuge, Tucker County, West Virginia 19992000. The same letter above bars indicates no difference $(P>0.05)$ between years. 


\title{
CHAPTER II
}

\section{NEST SITE PLACEMENT AND NEST SUCCESS OF GRASSLAND BIRDS IN CANAAN VALLEY, WEST VIRGINIA}

\begin{abstract}
Grassland bird populations have become increasingly dependent on altered grassland habitat for nesting in the eastern United States. Idle hayfields and pastures in the eastern United States are providing nesting habitat for grassland species displaced from their native habitat. The objective of this study was to compare grassland bird nest success and nest placement between 3 idle hayfields and 3 pastures, and 5 mowed and 6 unmowed treatments. This study was conducted in the Canaan Valley National Wildlife Refuge, West Virginia on 295 ha of grassland habitat. During the summer of 1999 and 2000, I searched and monitored grassland bird nests found on hayfields and pastures. At the conclusion of the 1999 field season, one-half of each field was mowed to manipulate the vegetation and determine the effects of a mowing treatment on nest site selection and success. The predominant grassland species were bobolinks (Dolichonyz oryzivorus), savannah sparrows (Passerculus sandwichensis), and eastern meadowlarks (Sturnella magna). Estimated Mayfield nest survival did not differ between nests found in hayfields and pastures, and mowed and unmowed treatments. Grassland species were found to place nests at sites with little to zero bare ground and woody cover, and were found at locations with increased vertical density and moderate to high litter depth. While there was no difference in nest success between mowed and unmowed treatments, mowing these fields at the conclusion of the breeding season will provide long term advantages to grassland birds nesting on the refuge.
\end{abstract}

This thesis follows the style of the Journal of Wildlife Management 
Key words: bobolink, Dolichonyz oryzivorus, eastern meadowlark, grassland birds, nest success, Passerculus sandwichensis, savannah sparrows, Sturnella magna, West Virginia.

While information does exist on nesting characteristics and habitat affinities of some upland nesting birds of the grasslands of the northern United States and Canada, it is important to determine the nesting characteristics and habitat affinities of grassland birds on a regional/local scale (Kantrud and Higgins 1992). In the eastern United States most research on grassland birds has been conducted on active hayfields and pastures, and reclaimed strip mines (Whitmore and Hall 1978, Wray et al. 1978, Bollinger et al. 1990, Norment et al. 1999). Idle hayfields and pastures are increasing in the eastern United States due to changes in farming practices and the purchase of farmlands for other uses. These new habitats present managers increased opportunities to enhance the quality of habitat for declining grassland birds (Farris and Cole 1981). Many grassland bird species adapted and expanded their populations throughout the Northeast in the 1800s as land was cleared for timber harvest and agriculture (Jones and Vickery 1997). Wray et al. (1978) found grassland species of the reclaimed mine community in West Virginia included grasshopper sparrows (Ammodramus savannarum) vesper sparrows (Pooecetes gramineus), savannah sparrows (Passerculus sandwichensis), horned larks (Eremophila alpestris), red-winged blackbirds (Agelaius phoeniceus), and eastern meadowlarks (Sturnella magna). Additional species found in pastures and hayfields of West Virginia include bobolinks (Dolichonyx oryizorus), field sparrows (Spizella pusilla), and chipping sparrows (Spizella passerina).

The most frequently cited explanation for grassland bird population declines in fragmented habitats is higher nest depredation rates near edges (Paton 1994, Burger eta 1. 
1995, Herkert et al. 1996, Winter 1999). Increased predation on nests of ground-nesting species on prairie fragments may cause population declines or loss of some prairie bird species. Miller et al. (1998) listed nest predation as the most important cause of nest failure. Winter (1998) found an elevated frequency of nest depredation on nests near a woody edge. However, while Warren and Ryan (1999) observed higher depredation rates near grassland edges differences between depredation rates in the prairie interior and the woody edge were not detected. A sharp forest to grassland edge may act as a biological barrier and concentrate predator activity along a woody edge (Johnson and Temple 1990, Burger et al. 1994, Winter 1998). In Minnesota, nest success was lower on small prairie fragments (16-32 ha), than on large prairie fragments (130-486 ha) due to higher nest depredation on smaller prairie fragments (Johnson and Temple 1990, Herkert et al. 1996). Other reasons for grassland bird decline include: insufficient breeding habitat, inadequate reproduction, or excessive annual mortality (Temple 1988). Loss of nests to predators is common, but if predators become overabundant they can reduce the normal nest success of birds (Temple 1988).

In the northeast, most grassland birds use hayfields, pastures, and meadows for breeding while many other birds nest nearby and use crop fields and open areas for hunting and foraging (Jones and Vickery 1997). During the breeding season, invertebrates are a critical food resource for many grassland birds and nestlings (O'Leske et al. 1997). There is evidence to suggest that having highly fragmented grassland habitats may reduce rates of insect colonization at grassland sites (Collinge 2000). This may reduce overall insect productivity and limit resources needed for avian species, particularly throughout their breeding seasons. 
Management of farmlands can be detrimental or beneficial to grassland birds. The use of hayfields can significantly reduce reproductive success for grassland birds because timing of mowing often conflicts with their breeding season (Bollinger 1995). Bollinger et al. (1990) estimated a 40\% mowing-induced mortality rate for bobolink nests found on hayfields in New York. Additional studies have noted direct loss of nests due to mowing during grassland bird breeding seasons (Bollinger et al. 1990, Frawley and Best 1991, Dale et al. 1997, Herkert et al. 1998). If timing of mowing is delayed until the conclusion of grassland bird breeding seasons, mowing treatments may benefit grassland birds. The benefits of mowing fields include: setting back succession, controlling woody vegetation, lowering vegetative height, and reducing litter build-up (Sample and Hoffman 1989).

In West Virginia, some information has been collected on the nesting success of grassland birds on reclaimed mine sites (Whitmore and Hall 1978, Wray et al. 1978), but information is lacking on the success of grassland birds nesting in farmlands throughout West Virginia. Additionally, little is known about the response of grassland nesting species to mowing treatments in West Virginia. Nest fate and nest site characteristics were determined for bobolinks, eastern meadowlarks, red-winged blackbirds, and savannah sparrows found on the hayfields and pastures of the Canaan Valley National Wildlife Refuge (CVNWR), Canaan Valley, WV, during the 1999 and 2000 breeding seasons. Additionally, insect biomass was collected to determine food resources available for breeding grassland birds.

My objectives of this study were to: 1) determine nest fate and extent of depredation, 2) determine nest site selection based on the collection of vegetative information at nest sites and random sample locations, 3) determine insect availability to 
grassland nest species and their nestlings, and 4) develop management recommendations for grassland species on the CVNWR. Overall, I hypothesized that there would be fairly high rates of nest depredation because the farmlands on the refuge were highly fragmented. Additionally, I hypothesized there would be differences in nest fate between hayfields and pastures because the sites were highly variable in size and vegetative composition. I hypothesized that mowed treatments on both hayfields and pastures would promote nest success because of the removal of large amounts of dead vegetation on both hayfields and pastures.

\section{STUDY SITE}

The study was conducted on the grassland portion of the CVNWR in Canaan Valley (Tucker County), West Virginia (Figure 1). The valley consists of a large wetland system ( 2,438 ha) made up of meadows, boggy terrain, beaver ponds and boreal forests. Temperatures in the summer are typically cool with an average from $24-26^{\circ} \mathrm{C}$ during the day and $10-13^{\circ} \mathrm{C}$ in the evenings. Due to the cool climate in the valley, flora is composed of plants with northern ranges and distributions and for some species Canaan Valley is the southern most extent of their range (Fortney 1993). Canaan Valley, in normal year, has about $114 \mathrm{~cm}$ in total rainfall accumulation (National Oceanic and Atmospheric Administration 1999). During 1999, total yearly rainfall was $96 \mathrm{~cm}$ with lower rainfall in June-September when compared to rainfall accumulation in a normal year (Figure 2). Additionally, West Virginia experienced a statewide drought during the summer 1999. In 2000, total rainfall $(113 \mathrm{~cm})$ was similar to rainfall in a normal year (National Oceanic and Atmospheric Administration (Figure 2). 
Grasslands comprise about 295 ha of the refuge. The dominant grassland vegetation present on the refuge consists of orchard grass (Dactylis glomerata), mountain oat grass (Danthonia compressa), sweet vernal grass (Anthoxanthum odoratum), quackgrass (Agropyron repens), timothy (Phleum pratense), bog goldenrod (Solidago uliginosa), wrinkle-leaved goldenrod (Solidago rugosa), cinquefoil (Potentilla spp.), St. John's Wort (Hypericum spp.), and narrow-leaved meadowsweet (Spirea alba) (Appendix V). Dominant species found at grassland bird nest sites include: reed canary grass (Phalaris arundinacea), mountain oat grass (Danthonia compressa), cinquefoil (Potentilla spp.), narrow-leaved meadowsweet (Spirea alba), wrinkle-leaved goldenrod (Solidago rugosa), and bog goldenrod (Solidago uliginosa) (Table 1). A full list of vegetation found at bobolink, eastern meadowlark, red-winged blackbird, and savannah sparrow nest sites can be found in Appendix V.

\section{METHODS}

The study was conducted on grasslands previously used as hayfields (Beall, Harper, and Thompson) or pastures (Cortland, Freeland, and Hertz). At the conclusion of the 1999 grassland bird breeding season, one-half of the grassland portions of Beall, Cortland, Freeland, Harper, and Thompson were mowed to determine the effects of habitat manipulation on breeding bird success. Hertz was not mowed because the tract was inaccessible to farm equipment due to saturated soil conditions.

\section{Nest Location}

Each tract was searched for nests by walking and observing bird nesting behaviors. Nest searches were conducted daily throughout the 1999 and 2000 breeding 
seasons. Nests were flagged $5 \mathrm{~m}$ north of the nest to minimize disturbance (Davis and Sealy 1998), except in cases where nest placement was obvious and flags may have provided visual cues to avian predators. Nests were monitored every 3-5 days to determine clutch size and nest fate. When nests became inactive, nest fate was classified into fledged, depredated, or abandoned categories. If nestlings were ready to fledge when the nest became inactive and the nest site was in good condition, the nest was considered to have fledged young. Depredated nests were those where the eggs were taken or nestlings were taken before their average fledging dates. Abandoned nests were those where the female or both parents were not present during nest checks, or nests that were found before egg laying occurred and females abandoned. Nest searches during the 2000 field season were conducted on both mowed and unmowed plots to determine whether field manipulation would affect nest site placement and fate.

\section{Nest Site Characteristics}

Once a nest became inactive, vegetative characteristics were recorded at each nest site based on methods of Best et al. (1997). Vertical density $(\mathrm{cm})$, maximum height $(\mathrm{cm})$, litter depth (cm), and canopy coverage were measured using a Robel pole (Robel et al. 1970) and Daubenmire frame (Daubenmire 1959). The Robel pole, with a height of $1 \mathrm{~m}$, was used to obtain visual obstruction readings at $4 \mathrm{~m}$ away from the pole (Robel et al. 1970). The maximum height of either living or dead plant material was recorded within 2 $\mathrm{cm}$ of the Robel pole. Vegetative canopy coverage was determined using a Daubenmire sampling frame (Daubenmire 1959). Ground cover, which equaled 100\%, was classified into canopy cover, litter cover, and bare ground cover. Canopy coverage was then classified into the following groupings: living or standing-dead vegetation; and forbs, 
grasses, and woody vegetation (Best et al. 1997). Living and standing-dead vegetation equaled the percentage of canopy cover. Additionally, the forbs, grasses, and woody vegetation equaled the amount of percent canopy cover. Litter included all dead plant material laying on the soil surface, including decomposing material. Standing-dead vegetation included all dead plant material found above the litter layer and therefore, considered in maximum height and visual obstruction readings. Additionally, vegetative species found within the Daubenmire (1959) frame were recorded to determine dominant vegetation at the nest site. This process was repeated at a random point within the same field either in June, July, or August depending on the time the nest became inactive.

\section{Invertebrate sampling}

Invertebrate sampling was conducted based on methods outlined by O'Leske et al. (1997). Samples were collected by sweepnet once each month in June, July, and August along permanently established strip transects. Collection took place between 1000-1500 hours on days where cloud cover is $<50 \%$, wind speed $<20 \mathrm{kph}$, and ambient temperature is between $16-50^{\circ} \mathrm{C}$ (Robel et al. 1996, O’Leske et al. 1997). At each plot, 3 samples were taken, each consisting of 50 full sweeps per sample through the upper level of vegetation. The contents of the sweepnet were placed in ethyl-acetate kill jars, and the specimens were subsequently transferred to labeled plastic bags and frozen.

Invertebrate numbers and biomass were determined by separating the thawed invertebrates from vegetative debris, allowing them to air dry, and then sorting them to family (O’Leske et al. 1997). Once separated to order or family when possible, they were dried to a constant mass at $70^{\circ} \mathrm{C}$ for $\geq 48$ hours. Once these measurements were determined they were recorded to $0.0001 \mathrm{~g}$ by taxa. 


\section{Statistical Analysis}

Statistical analyses for nest data were conducted on total number of nests for each species by breeding season (1999 and 2000) and location. Nest fate data for bobolinks, eastern meadowlarks, red-winged blackbirds, and savannah sparrows were analyzed using the modified Mayfield method (Mayfield 1975, Johnson 1979). These 4 species were the most abundant nesting species found on the refuge. Total survival, or probability of nesting success for the entire nesting period, and daily nest survival were calculated. Nests were considered successful if there was evidence that at least one nestling fledged. Nests were considered unsuccessful if nestlings were taken before their projected fledging date or there was evidence of predation at the nest site. During 2000, I used 2-way analysis of variance (ANOVA) to compare nest success (dependent variable) between treatments (mowed or unmowed) and habitat types (hayfields and pastures) (independent variables). Following these analyses, data were analyzed using 2-way ANOVAs to compare nest success between habitat types (hayfields and pastures) and years (1999 and 2000) for combined 1999-2000 data. Data were checked for normality using Shapiro-Wilk Statistic and homogeneity of variances by plotting residuals (Cody and Smith 1991).

The nest vegetation data for each species were analyzed using stepwise discriminant function analysis (DFA) to determine which variables were important in identifying nest site location for individual species (Wray 1979). I also used DFA to determine the effect vegetation variables had on nest success, where nests found for each species were divided into 2 groups, successful and unsuccessful. For discriminating between nest sites and sample locations, bobolink, eastern meadowlark, red-winged 
blackbird, and savannah sparrow nest data for 2000 treatments and years were analyzed separately. For discriminating between successful and unsuccessful nests, bobolinks, red-winged blackbirds, and savannah sparrow nest data for 2000 treatments and years were analyzed separately. Successful and unsuccessful eastern meadowlark nests were not analyzed using discriminant function analysis due to low sample sizes. Vegetative variables were entered into the model using $\operatorname{SLE}=0.25$, which specifies the significance level for adding variables in the forward selection mode (SAS/STAT 1990). The habitat measurements (dependent variables) were placed into 3 categories: cover type (canopy, litter, and bare ground), growth state (live and dead standing vegetation), and vegetative type (forb, grass, and wood). These categories were formed because the total growth state and vegetative type equal percent canopy cover. All percentage data were arcsine square root transformed and height data were log transformed. Canopy cover and standing live vegetation were excluded from analysis because percent vegetative type is a component of these 2 and is expected to account for these variables.

Invertebrate biomass data were analyzed by 3-way ANOVA using a model that included habitat types, treatments, and months for 2000 data and habitat types, years, and months for 1999 and 2000 data (Robel et al. 1996). All Mayfield nest survival data and associated ANOVAs and insect biomass data were significant at $P<0.05$. Following a significant ANOVA, I used Tukey's multiple comparison test to separate means. Interaction effects will only be listed in the text if they are significant. All other interaction terms can be found in Appendix I. Stepwise DFA tests on nest sites and nest fate were significant at $P<0.10$ to include more vegetative variables in the analysis. 
Means and standard errors for DFA can be found in Appendix VI. Additionally, average biomass of invertebrate orders found on the refuge can be found in Appendix VII.

\section{RESULTS}

Overall, there was a total of 89 grassland bird nests were found during 1999 and 2000: bobolinks (26 nests), eastern meadowlarks (11 nests), red-winged blackbirds (21 nests), savannah sparrow (25 nests), chipping sparrows (7 nests), common yellowthroats ( 2 nests), vesper sparrows (1 nest), and mallard (1 nest) (Table 2). Thirty-two additional nests were located but these were from non-grassland birds and are not discussed in this chapter. Overall mean clutch size for bobolinks, eastern meadowlarks, red-winged blackbirds, and savannah sparrows were 4.36, 4.73, 3.75, and 3.92 respectively (Table 3). Nest initiation for most grassland species on the refuge occurred during the second to third week in May. For both years, the first nest was found the third week in May. Most nests were found during June on the Freeland, Thompson, and Beall tracts.

\section{Nest Fate}

All of the tracts but 2 (Cortland and Harper) on the CVNWR had active nests on them during both years (Table 4). There were no differences in nest density for all grassland nesting species between mowed $(\overline{\mathrm{x}}=0.64, \mathrm{SE}=0.35)$ and unmowed $(\overline{\mathrm{x}}=$ $1.18, \mathrm{SE}=0.64)$ treatments during $2000(F=0.01 ; \mathrm{df}=1,5 ; P=0.934)$. Additionally, there were no differences in nest density (number/ha) between $1999(\bar{x}=0.17, \mathrm{SE}=$ $0.08)$ and $2000(\overline{\mathrm{x}}=0.93, \mathrm{SE}=0.45)(F=1.88 ; \mathrm{df}=1,4 ; P=0.242)$, or between hayfields ( $\overline{\mathrm{x}}=0.54, \mathrm{SE}=0.34)$ and pastures $(\overline{\mathrm{x}}=0.56, \mathrm{SE}=0.43)(F=0.01 ; \mathrm{df}=1,4$; $P=0.977)$. Daily nest survival and total survival were determined for bobolinks, eastern 
meadowlarks, red-winged blackbirds, savannah sparrows and all grassland nesting species for both years (Table 4).

There was no interaction between habitat types and treatments for nest success during $2000(F=0.11 ; \mathrm{df}=1,3 ; P=0.761)$. Also, nest success between mowed $(\overline{\mathrm{x}}=$ $0.40, \mathrm{SE}=0.15)$ and unmowed $(\overline{\mathrm{x}}=0.22, \mathrm{SE}=0.02)$ treatments was similar $(F=0.68$; df 1,$3 ; P=0.472$ ). Additionally, there were no interactions between habitat types and years $(F=0.49 ; \mathrm{df}=1,6 ; P=0.511)$. Differences in nest success were not detected between hayfields or pastures $(F=0.16$; $\mathrm{df}=1,6 ; P=0.705$ or between years $(F=0.16$; df $=1,4 ; P=0.714$ ) for $1999-2000$ combined data. This information was used to determine the effect each habitat type had on nest fate. Using total survival per plot, idle hayfields ( $\overline{\mathrm{x}}=0.304, \mathrm{SE}=0.083)$ and idle pastures $(\overline{\mathrm{x}}=0.233, \mathrm{SE}=0.129)$ were similar $(F=0.16, \mathrm{df}=1,5, P=0.712)$. Also, there was no difference between $1999(\overline{\mathrm{x}}=$ $0.194, \mathrm{SE}=0.02)$ and $2000(\overline{\mathrm{x}}=0.321, \mathrm{SE}=0.088)(F=0.01, \mathrm{df}=1,5, P=0.920)$. Based on high $P$-values from the $F$-test results, I believe if sample sizes were doubled or tripled differences still would not be detected. This indicates that the results are reliable and not due to low sample size.

\section{Difference between nest and random sites}

For bobolinks, differences were detected for percent bare ground, standing dead vegetation, and percent litter. Percent bare ground was greater at random locations than at nest locations $(F=8.58 ; P=0.005)$ (Table 7). Percent litter was higher at bobolink nest sites than at random locations $(F=3.39 ; P=0.072)$ (Table 7). Additionally, standing dead vegetation was taller at nest sites than at random locations $(F=4.07 ; P=0.049)$ (Table 7). 
For eastern meadowlarks, standing dead vegetation was taller at nest sites $(F=$ 15.24; $P=0.001)$, litter depth was higher at nest sites $(F=6.37 ; P=0.021)$, and maximum height also were higher at eastern meadowlark nest sties than random sites $(F$ $=18.44 ; P=0.0004)($ Table 7$)$. For savannah sparrows, standing dead vegetation was taller at nest sites than at random locations $(F=7.16 ; P=0.010)$ and percent grass was higher at nest sites than at random locations $(F=3.55 ; P=0.066)$ (Table 7).

Maximum height of vegetation was taller at red-winged blackbird nest sites than random locations $(F=63.70 ; P<0.001)$ (Table 7). Percent wood also was greater at nest sites $(F=10.02 ; P=0.003)($ Table 7$)$. Percent litter, however, was higher at random locations than at red-winged blackbird nest sites $(F=12.09 ; P=0.001)$ (Table 7$)$. Differences in Nest Fate between Vegetative characteristics

For bobolinks, vertical density of vegetation was taller at successful nests than at unsuccessful nests $(F=4.20 ; P=0.052)$ (Table 8$)$. However, vertical density of vegetation was greater at depredated savannah sparrow nests than at successful nests $(F=$ $7.00 ; P=0.015)$ (Table 8). Maximum height of vegetation was taller at successful savannah sparrow nests than at unsuccessful nests $(F=4.60 ; P=0.043)$. For red-winged blackbirds maximum height was taller at successful nests than depredated nests $(F=$ 5.89; $P=0.027$ ) (Table 8). Additionally, depredated red-winged blackbird nests were found further from field edges than successful nests $(F=4.22 ; P=0.057)$ (Table 8$)$.

\section{Invertebrate biomass}

There were no differences between mowed ( $\bar{x}=0.03, \mathrm{SE}=0.01)$ and unmowed $(\overline{\mathrm{x}}=0.03, \mathrm{SE}=0.01)$ treatments for invertebrate biomass $(F=0.03 ; \mathrm{df}=1,12 ; P=$ 0.867) during 2000. A 3-way interaction was detected among years, habitat types, and 
months $(F=5.95 ; \mathrm{df}=2,12 ; P=0.008)$ for 1999 and 2000 combined. There were no differences in invertebrate biomass between hayfields ( $\bar{x}=0.04, \mathrm{SE}=0.01$ ) and pastures $(\overline{\mathrm{x}}=0.04, \mathrm{SE}=0.01)$ in June $2000(F=0.73 ; \mathrm{df}=1,4 ; P=0.441)$ or between hayfields $(\overline{\mathrm{x}}=0.04, \mathrm{SE}=0.01)$ and pastures $(\overline{\mathrm{x}}=0.03, \mathrm{SE}=0.01)$ in July $2000(F=3.41 ; \mathrm{df}=1$, 4; $P=0.139)$. However, invertebrate biomass was greater in pastures $(\overline{\mathrm{x}}=0.03, \mathrm{SE}=$ $0.01)$ than hayfields ( $\overline{\mathrm{x}}=0.02, \mathrm{SE}=0.01)$ in August $2000(F=14.37 ; \mathrm{df}=1,4 ; P=$ 0.019). There were no differences in invertebrate biomass between hayfields ( $\bar{x}=0.03$, $\mathrm{SE}=0.01)$ and pastures $(\overline{\mathrm{x}}=0.01, \mathrm{SE}=0.01)$ in June $1999(F=3.69 ; \mathrm{df}=1,4 ; P=$ 0.127), between hayfields ( $\bar{x}=0.02, \mathrm{SE}=0.01$ ) and pastures ( $\overline{\mathrm{x}}=0.02, \mathrm{SE}=0.01)$ in July $1999(F=2.08 ; \mathrm{df}=1,4 ; P=0.223)$, or between hayfields ( $\overline{\mathrm{x}}=0.023, \mathrm{SE}=0.004)$ and pastures ( $\overline{\mathrm{x}}=0.02, \mathrm{SE}=0.01)$ in August $1999(F=0.09 ; \mathrm{df}=1,4 ; P=0.779)$.

\section{DISCUSSION}

\section{Nest Success Rates on Mowed Treatments and Habitat Types}

Nest success was similar between mowed and unmowed treatments indicating that while the vegetative structure was altered it did not alter nest failure rates. Even though nests found in the mowing treatment had similar nest success rates when compared to unmowed treatments, it is possible mowing conducted during the non-breeding season may positively influence nest success in the future. Mowing should decrease woody cover and set back succession and create more favorable nesting habitat for grassland birds. Also, nest success was similar between hayfields and pastures for 1999 and 2000. This indicates previous farming techniques used on these plots is affecting grassland bird 
nest success equally. The hayfields and pastures on the refuge appear to be providing similar nesting habitat for grassland birds.

Savannah sparrow nesting success was $34 \%$ in Canaan Valley, which is higher than the 25\% fledging rate on reclaimed mine sites in West Virginia (Wray 1979), in Nebraska (15.5\%) and Minnesota (1.9\%) conservation reserve fields (CRP) (Koford 1999), and in Nebraska (22\%) and Minnesota (24.9\%) waterfowl production areas (Koford 1999). Davison and Bollinger (2000) estimated a 62\% fledging success for bobolinks, which is much higher than the $19.4 \%$ fledging success found on the Canaan Valley NWR. Also, Koford (1999) estimated a 47.3\% fledging success for bobolinks in Nebraska. In Minnesota, however, a 9.6\% fledging success rate was estimated, which is lower than the $19.4 \%$ fledging success of bobolinks on the Canaan Valley NWR. Overall, while bobolink fledging percentages may appear to be relatively low they may be sufficient to maintain stable populations without immigration (Koford 1999).

Eastern meadowlark fledging success was $70 \%$ in Canaan Valley, which is much higher than the 32\% fledging rate in Illinois (Davison and Bollinger 2000) and the $29.9 \%$ fledging rate in northern Missouri (McCoy et al. 1999). Red-winged blackbird fledging success was $21 \%$ in Canaan Valley, which was similar to fledging estimates (28\%) found in northern Missouri (McCoy et al. 1999) and Illinois (20\%) (Davison and Bollinger 2000).

Overall, $82 \%$ of nest failures for grassland nesting birds on the refuge were a result of depredation. Other studies have cited nest predation as the main reason for nest failure (Wray 1979, Patterson and Best 1996, Winter 1999). Wray (1979) found that $78 \%$ of unsuccessful nests taken by predators were the result of bird or snake depredation 
in West Virginia. Potential nest predators in Canaan Valley may include: shrews (Sorex spp.), white-footed mouse (Peromyscus leucopus), meadow vole (Microtus pennsylvanicus), striped skunk (Mephitis mephitis), red fox (Vulpes vulpes), raccoon (Procyon lotor), chipmunk (Tamias striatus), whitetail deer (Odocoileus virginianus), American crow (Corvus brachyrhynchos), northern black racers (Coluber constrictor constrictor), and black rat snakes (Elaphe obsoleta obsoleta) (United States Fish and Wildlife Service 1979). Although not measured in this study, most failed nests exhibited some form of destruction possibly caused by small to medium sized mammals.

\section{Bobolinks}

During 2000, bobolinks were found nesting on the mowed portion of the Beall tract, but they were not found on Beall during their breeding season in 1999. Mowing in 1999 may have created additional habitat for bobolinks during the 2000 breeding season. Bobolink nests found on the refuge during $2000(n=21)$ had lower percentages of bare ground, percent litter, and standing dead vegetation at nest sites when compared to random sampling locations. Bobolinks tended to build nests at sites with a substantial amount of cover providing nest concealment and protection. Because adequate cover is an important characteristic for bobolink nest sites, bare ground was not present at nests sites. Previous studies have found that bobolinks prefer moderate to tall vegetation, moderate to dense vegetation, and a moderate to deep litter layer (Bollinger 1995, Dechant et al. 1999). The strongest predictor of bobolink presence is decreasing bare ground, increasing litter, and increasing vegetative density (Dechant et al. 1999). Total vertical vegetative density has been found to be higher near nest sites than throughout the entire habitat sampled (Martin and Gavin 1995). The Freeland tract (i.e., pasture) had 
higher densities of nesting species than most tracts on the refuge. This particular tract positively responded to the mowing treatment and normal rainfall thereby increasing variables like live vegetation, vertical density, and maximum height.

Bobolink nests that successfully fledged young had greater vertical densities of vegetation when compared to depredated nests. Vertical density provided nest concealment from predators, shelter from environmental factors, and appear to contribute to bobolink nest success. Idle pastures appear to be providing suitable habitat for bobolinks because they provide areas with dense, tall vegetation that provides vertical density. Nests that fledged young in mowed and unmowed treatments had nearly equal vertical densities suggesting obstruction $>28 \mathrm{~cm}$ is beneficial to bobolink nest success. The effects of mowing on bobolinks have been found to be detrimental (Frawley 1989, Bollinger et al. 1990). In New York, mowing directly destroyed 51\% of bobolink nests, with an additional 10\% loss when follow-up raking and bailing occurred (Bollinger et al. 1990). In Iowa, $50 \%$ of ground nests in alfalfa fields were destroyed during mowing (Frawley 1989). While direct effects of mowing on nest fate is an issue on active farmlands, these effects are not a concern on the CVNWR grasslands. Mowing was conducted at the conclusion of the breeding season, not during nesting when farmers would receive the maximum productivity from hay.

\section{Savannah Sparrows}

Savannah sparrow nests were found on nearly all sites with the exception of Cortland and Harper. They appear to choose their nest locations without regard to the dominant vegetation found on each site and their nests were in vegetation ranging from moss to reed canary grass. There were few differences between savannah sparrow nest 
sites and random locations in 2000 , although percent standing dead vegetation and percent grass were higher at nest sites than sample locations. Savannah sparrows have established territories in habitats with significantly greater grass cover and nests may be concealed by a canopy and dead grasses and herbs (Wheelwright and Rising 1993).

Savannah sparrows nesting on the refuge were found on nearly all plots and appear to be habitat generalists when it comes to selecting quality nest sites.

In discriminating between vegetative characteristics found at successful and unsuccessful savannah sparrow nests, maximum height and vertical density were found to be higher at unsuccessful nest sites. Savannah sparrow nests that fledged young had higher maximum heights than those nests that failed. Wray (1979) found successful nests of vesper, grasshopper, and savannah sparrows had increased amounts of tall $(>30 \mathrm{~cm})$ vegetation on reclaimed mine sites in West Virginia. Mean height also was higher at successful savannah sparrow nests found on reclaimed mine sites (Wray 1979). Additionally, higher percentages of grass were found at nest sites and sampling locations in pastures. Percent grass did not appear to have an effect on savannah sparrow nest fate. While litter depth did not effect savannah sparrow nest success on the refuge, Dale et al. (1997) found savannah sparrow site use was positively correlated with litter depth and broad-leaved grasses in Saskatchewan.

\section{Eastern Meadowlarks}

Few nests were found for eastern meadowlarks $(n=11)$, which either may be a result of their relatively large territories, lack of suitable habitat within the study area, or that many nests that were present were not found. Eastern meadowlarks were not found where dominant vegetation included St. John's wort or narrow-leaved meadowsweet. 
Based on bird count data, eastern meadowlark densities were low indicating that the habitat in this situation did not provide adequate resources.

Standing dead vegetation, maximum height, and litter depth were higher at nest sites than at sample locations. While I found nest sites to be positively related to standing dead vegetation, McCoy (1996) found eastern meadowlark presence in CRP fields in Missouri to be negatively correlated to standing dead vegetation. In Canaan Valley, nests were typically found in clumps of dead vegetation. Various studies have found eastern meadowlarks prefer habitat with increased litter cover and dense vegetation (Rotenberry and Wiens 1980, Bollinger 1995, Lanyon 1995). However, Delisle and Savidge (1997) found eastern meadowlarks to be negatively correlated to litter depth. Because of low sample size for successful and unsuccessful nests, differences in vegetative variables between the 2 groups could not be determined for eastern meadowlarks. Hull (2000) found that optimal habitat for eastern meadowlarks contains low shrub cover $(<5 \%)$. Hull (2000) also noted that eastern meadowlarks tend to avoid areas with heavy woody invasion. The presence of large amounts of shrub habitat on the Thompson and Hertz tract did not provide suitable habitat for nesting eastern meadowlarks. Eastern meadowlarks were not present on Hertz and were found nesting at low densities on the Thompson tract. While differences in Mayfield nesting success among mowed and unmowed treatments were not detected, it would be advantagous to continue mowing portions of the refuge to deter woody vegetation and provide additional habitat for nesting eastern meadowlarks. Dale et al. (1997) found western meadowlarks consistently in annual hayfields. In my study, eastern meadowlarks were rarely found on sites with large amounts of woody cover and typically avoided woody cover when choosing a nest 
site. Additionally, Norment et al. (1999) found eastern meadowlarks on only a small number of fields in New York. Haying would decrease the amount of woody cover on idle farmland sites and perhaps create additional habitat for eastern and western meadowlarks during their breeding seasons.

\section{Red-winged Blackbird}

Red-winged blackbird nests were found where large stands of reed canary grass, narrow-leaved meadowsweet, or St. John's wort occurred. Their nests appeared to be particularly susceptible to American crow predation, which they were frequently seen mobbing. Percent litter, percent wood, and maximum height were greater at red-winged blackbird nest sites than random locations. However, LeClerc (1982) found red-winged blackbirds occupying habitats with deep litter accumulations and lush, dense grass cover in reclaimed strip mines in West Virginia. In Canaan Valley, red-winged blackbirds were found nesting in areas with increased shrub cover and maximum height, and decreased percent litter. These habitat characteristics, particularly increased shrub cover, are the opposite extreme from significant vegetative characteristics found for bobolinks, eastern meadowlarks, and savannah sparrows.

Successful red-winged blackbird nests had greater maximum heights and were found closer to edges than unsuccessful nests, based on significant variables entered in the discriminant function analysis model. Red-winged blackbirds were the only grassland nesting species where nest fate was positively related to distance to edge in Canaan Valley. Because successful nests were found closer to edges than unsuccessful nests, it is likely the amount of overhead concealment provided by increased maximum heights is the greatest indicator of red-winged blackbird nest success. Overhead 
concealment could provide protection from avian predators that forage using visual cues (Wray 1979).

\section{Invertebrate Food Availability for Grassland Nesting Species and their Nestlings}

While invertebrate biomass differed between habitat types over months no significant differences were detected for hayfields and pastures. Invertebrate biomass was higher in 2000 than in 1999 . Populations of invertebrates were likely responding to the increased average rainfall in 2000 and the drought conditions of 1999. Insect orders that may provide important food for grassland birds and their nestlings on the refuge were: Coleoptera, Homoptera, Lepidoptera, and larvae of Diptera, Coleoptera, and Lepidoptera. In Illinois, bobolinks fed nestlings primarily Lepidoptera and Orthoptera larvae, eastern meadowlarks primarily consumed Coleoptera and Lepidoptera, and redwinged blackbirds fed nestlings Odonata and Lepidoptera (Kobal et al. 1998). The diet of nestling bobolinks consists of Lepidoptera, Diptera, Hymenoptera, and Coleoptera adults and larvae, Hemiptera and Orthoptera adults and nymphs, and Arachnida (Martin and Gavin 1995). Eastern meadowlarks feed nestlings insect food almost exclusively and stomach contents revealed chiefly Orthopterans, and Lepidoptera and Diptera larvae(Lanyon 1995). The diet of nestling savannah sparrows consisted of Coleoptera, Diptera, Lepidoptera, Hymenoptera adults and larvae, and Homoptera (Cercopidae, Cicadellidae) and Orthoptera adults and nymphs (Meunier and Bedard 1984, Wheelwright and Rising 1993). While information does not exist on the exact orders fed to nestlings on the refuge, the orders found to consist of the majority of grassland bird species diets were the dominant invertebrate orders collected during sweepnet sampling. 
Because of the constraints on sweepnet sampling, it is difficult to determine overall invertebrate productivity and if it can sustain grassland birds during the breeding season.

\section{Management Implications}

Wray et al. (1982) stated that an annual productivity rate of at least 8 fledglings per pair is necessary to balance $50 \%$ adult mortality for birds with a fledgling survival to the first breeding season of $12.5 \%$. The grassland species found on the refuge fledge between 2-5 fledglings/successful nest attempt. Bobolinks, which are typically a single brooded species, did not make enough nest attempts to yield productivity rates greater than 8 fledglings. Only savannah sparrows, which can have triple broods, have the capacity to produce more than 8 fledglings in a nesting season; although, there was no evidence of this on the CVNWR. While productivity rates are not high enough for population maintenance without recruitment if adult mortality exceeds $50 \%$, management of Canaan Valley grasslands may enhance productivity in the future. Additionally, adult mortality may be low enough to maintain a sustainable population.

Grassland sites need to be large enough to support grassland populations. Vickery et al. (1994) suggests that grassland sites need to be $>50$ ha, preferably about 200 ha. In West Virginia, sites are better suited for grassland birds if they are over 40 ha, because smaller sites ( $<40 \mathrm{ha}$ ) are subject to high turnover rates, rapidly fluctuating populations, and numerous extinctions (Whitmore 1980). On the refuge, the sites with the greatest number of target species individuals were not necessarily the largest sites (28 93 ha) indicating habitat quality not size was more important to nest site location. Large tracts of grasslands (>100 ha) should be managed to enhance habitat quality and promote grassland bird recruitment. Grassland species appeared to be responding to the vegetative 
structure and vertical diversity found on these sites rather than field size, which is similar to the findings of Bollinger (1995). Although, bobolinks, eastern meadowlarks, and savannah sparrows do not necessarily need areas greater than 100 ha, other species such as grasshopper sparrows, found during 2000 on the Beall tract (93 ha site), do require larger areas (Jones and Vickery 1997).

A combination of mowing, grazing, and prescribed burning should be implemented to provide quality habitat by setting back succession for grassland species. These management techniques are necessary to prevent woody encroachment in habitat fragments and may reduce predation on ground nests (Burger et al. 1994). Herkert et al. (1996) found that providing a mosaic of mowed/unmowed, grazed/ungrazed, or burned/unburned areas provides a full range of grassland bird habitat requirements, and accounts for the different responses grassland species have to management techniques. While some species like eastern meadowlarks and savannah sparrows prefer developed litter layers, mowing or another management technique needs to be implemented before the litter layer becomes too dense and is unsuitable for nest site selection. Jones and Vickery (1997) found that reproductive success improves if fields are mowed after July 31. On the refuge mowing should be conducted in mid-to-late August to avoid destroying nests of double or triple brooding species. It is important that with any management technique used that blocks of land remain idle for 1-4 years. This would provide cover for grassland species at the beginning of a breeding season and provide increased percent litter, standing dead vegetation, and litter depth for nest placement.

While distance to edge or field size did not have a detectable effect on bobolink or savannah sparrow nest fate, management should focus on removal of internal edges (i.e., 
remnant fence lines, hedgerows, and wind breaks) found throughout the grasslands on the refuge. These internal edges further fragment already highly broken up tracts of land and should be removed to provide large contiguous pieces of grasslands.

Although, leaving existing posts along roadsides may be favorable for species that use these structures as singing perches (i.e., eastern meadowlarks, savannah sparrows, grasshopper sparrows). These posts should not be detrimental to grassland birds because they are already associated with existing edge habitat and would not alter the interior portion of grassland tracts that should be more favorable as nesting habitat. However, structures (e.g., fencelines, hedgerows, creeks, and drainage ditches) located within grassland interiors have been found to concentrate activity of predators, which may increase nest predation rates (Heske et al. 2001).

\section{Further Research}

Most unsuccessful nests on the refuge were lost due to depredation but no information exists on predator densities found on and around the grassland portions of the refuge. Determining predator densities (e.g., small mammals and reptiles) would contribute to understanding the scope of nest loss on the refuge. Additionally, studies documenting the direct loss of eggs or nestlings from nests will provide information on which predators are frequent and infrequent nest predators. Focusing on predator populations would provide information for a comprehensive management plan that will benefit grassland birds on the refuge. Additional studies on food resource availability (i.e., invertebrates and seeds) and use will determine which grassland sites are providing adequate resources for grassland birds. It would be useful to incorporate invertebrate sampling with observations of grassland birds carrying food to their nestlings to 
determine what they are feeding on and if the refuge is providing adequate foraging resources. These data should be combined with energetics, productivity, and survival models to determine long-term sustainability of grassland bird populations on the refuge. 


\section{LITERATURE CITED}

Best, L. B., H. Campa, III, K. E. Kemp, R. J. Robel, M. R. Ryan, J. A. Savidge, H. P. Weeks, Jr., and S. R. Winterstein. 1997. Bird abundance and nesting in CRP fields and cropland in the Midwest: A regional approach. Wildlife Society Bulletin 25:864-877.

Bollinger, E. K. 1995. Successional changes and habitat selection in hayfield bird communities. Auk 112:720-730.

Bollinger, E. K., P. B. Bollinger, and T. A. Gavin. 1990. Effects of hay-cropping on eastern populations of the bobolink. Wildlife Society Bulletin 18:142-150.

Burger, L. D., L. W. Burger, and J. Faaborg. 1994. Effects of prairie fragmentation on predation on artificial nests. Journal of Wildlife Management 58:249-254.

Cody, R. P., and J. K. Smith. 1991. Applied statistics and the SAS programming language. Third edition. Elsevier Scientific Publications, New York, New York, USA.

Collinge, S. K. 2000. Effects of grassland fragmentation on insect species loss, colonization, and movement patterns. Ecology 81:2211-2226.

Cooper, R. J., and R. C. Whitmore. 1990. Arthropod sampling methods in ornithology. Studies in Avian Biology 13:29-37.

Cooper, R. J., P. J. Martinat, and R. C. Whitmore. 1990. Dietary similarity among insectivorous birds: influence of taxonomic versus ecological categorization of prey. Studies in Avian Biology 13:104-109.

Dale, B. C., P. A. Martin, and P. S. Taylor. 1997. Effects of hay management on grassland songbirds in Saskatchewan. Wildlife Society Bulletin 25:616-626. 
Daubenmire, R. F. 1959. A canopy coverage method of vegetation analysis. Northwest Science 35:43-64.

Davis, S. K., and S. G. Sealy. 1998. Nesting biology of the Baird's sparrow in southwestern Manitoba. Wilson Bulletin 110:262-270.

Davison, W. B., and E. Bollinger. 2000. Predation rates on real and artificial nests of grassland birds. Auk 117:147-153.

Dechant, J. A., M. L. Sondreal, D. H. Johnson, L. D. Igl, C. M. Goldade, A. L. Zimmerman, and B. R. Euliss. 1999. Effects of management practices on grassland birds: Bobolink. Northern Prairie Wildlife Research Center, Jamestown, North Dakota, USA.

Delisle, J. M., and J. A. Savidge. 1997. Avian use and vegetation characteristics of Conservation Reserve Program fields. Journal of Wildlife Management 61:318325.

Farris, A. L., and J. H. Cole. 1981. Strategies and goals for wildlife habitat restoration on agricultural lands. Transactions of North American Wildlife and Natural Resources Conference 46:130-136.

Frawley, B. J. 1989. The dynamics of nongame bird breeding ecology in Iowa alfalfa fields. Thesis, Iowa State University, Ames, Iowa, USA.

Frawley, B. J., and L. B. Best. 1991. Effects of mowing on breeding bird abundance and species composition in alfalfa fields. Wilson Society Bulletin 19:135-142.

Fortney, R. H. 1993. Canaan Valley - An area of special interest within the upland forest region. Pages 47-65 in S. L. Stephenson, editor. Upland forests of West Virginia, McClain Print Company, Parsons, West Virginia, USA. 
Herkert, J. R., D. W. Sample, and R. E. Warner. 1996. Management of Midwestern grassland landscapes for the conservation of migratory birds. Pages 89-116 in F. R. Thompson, III, editor. Management of Midwestern landscapes for the conservation of migratory birds. U. S. Forest Service General Commissioners 32:234-241.

Heske, E. J., S. K. Robinson, and J. D. Brawn. 2001. Nest predation and neotropical migrant songbirds: piecing together the fragments. Wildlife Society Bulletin 29:52-61.

Hull, S. D. 2000. Effects of management practices on grassland birds: eastern meadowlark. Northern Prairie Wildlife Research Center, Jamestown, North Dakota, USA.

Johnson, D. H. 1979. Estimating nest success: the Mayfield method and an alternative. Auk 96:651-661.

Johnson, R. G., and S. A. Temple. 1990. Nest predation and brood parasitism of tallgrass prairie birds. Journal of Wildlife Management 54:106-111.

Jones, A., and P. Vickery. 1997. Conserving grassland birds: Managing agricultural lands including hayfields, crop fields, and pastures for grassland birds. Grassland Conservation Program, Center for Biological Conservation, Massachusetts Audubon Society, Lincoln, Massachusetts, USA.

Kantrud, H. A., and K. F. Higgins. 1992. Nest and nest site characteristics of some ground-nesting, non-passerine birds of northern grasslands. Prairie Naturalist 24:67-83. 
Kobal, S. N., N. F. Payne, and D. R. Ludwig. 1998. Nestling food habits of 7 grassland bird species and insect abundance in grassland habitats in Northern Illinois. Transactions of the Illinois Academy of Science 91:69-75.

Koford, R. R. 1999. Density and fledging success of grassland birds in conservation reserve program fields in North Dakota and West-Central Minnesota. Studies in Avian Biology 19:187-195.

Lanyon, W. E. 1995. Eastern meadowlark (Sturnella magna). In The Birds of North American, No. 160 (A. Poole and F. Gill, eds.). The Academy of Natural Sciences, Philadelphia, PA, and The American Ornithologists' Union, Washington, D. C., USA.

LeClerc, M. G. 1982. Bird communities and vegetation structure of reclaimed surface mines in West Virginia. Thesis, West Virginia University, Morgantown, West Virginia, USA.

Martin, S. G., and T. A. Gavin. 1995. Bobolink (Dolichonyx oryzivorus). In The Birds of North American, No. 176 (A. Poole and F. Gill, eds.). The Academy of Natural Sciences, Philadelphia, PA, and The American Ornithologists' Union, Washington, D. C., USA.

Mayfield, H. F. 1975. Suggestions for calculating nest success. Wilson Bulletin 87:456466.

McCoy, T. D. 1996. Avian abundance, composition, and reproductive success on Conservation Reserve Program fields in northern Missouri. Thesis, University of Missouri, Columbia, Missouri, USA. 
McCoy, T. D., M. R. Ryan, E. W. Kurzejeski, and L. W. Burger, Jr. 1999. Conservation Reserve Program: Source of sink habitat for grassland birds in Missouri? Journal of Wildlife Management 63:530-538.

Meunier, M., and J. Bedard. 1984. Nestling foods of the savannah sparrow. Canadian Journal of Zoology 62:23-27.

Miller, S. G., R. L. Knight, and C. K. Miller. 1998. Influence of recreational trails on breeding bird communities. Ecological Applications 8:162-169.

National Oceanic and Atmospheric Administration. 1999. National Climatological Data: Canaan Valley, West Virginia. U. S. Department of Commerce, Washington, D. C., USA.

National Oceanic and Atmospheric Administration. 2000. National Climatological Data: Canaan Valley, West Virginia. U. S. Department of Commerce, Washington, D. C., USA.

Norment, C. J., C. D. Ardizzone, and K. Hartman. 1999. Habitat relations and breeding biology of grassland birds in New York. Studies in Avian Biology 19:112-121.

O’Leske, D. L., R. J. Robel, and K. E. Kemp. 1997. Sweepnet-collected invertebrate biomass from high- and low-input agricultural fields in Kansas. Wildlife Society Bulletin 25:133-138.

Paton, P. W. 1994. The effect of edge on avian nest success: How strong is the evidence? Conservation Biology 8:17-26.

Patterson, M. P., and L. B. Best. 1996. Bird abundance and nest success in Iowa CRP fields: the importance of vegetation structure and composition. American Midland Naturalist 135:153-167. 
Robel, R. J., J. N. Briggs, A. D. Dayton, and L. C. Hulbert. 1970. Relationships between visual obstruction measurements and weight of grassland vegetation. Journal of Range Management 23:295-298.

Robel, R. J., B. L. Henning, K. W. Johnson, K. E. Kemp, and K. E. Church. 1996. Effects of seasonal disking on seed production and invertebrate biomass. The Southwestern Naturalist 41:403-408.

Rotenberry, J. T., and J. A. Wiens. 1980. Habitat structure, patchiness, and avian communities in North American steppe vegetation: a multivariate analysis. Ecology 61:1228-1250.

Sample, D. W., and R. M. Hoffman. 1989. Birds of dry-mesic and dry prairies in Wisconsin. Passenger Pigeon 51:195-208.

SAS/STAT. 1990. SAS/STAT User's Guide, Release 6.03 ed. SAS Inst., Cary, North Carolina, USA.

Temple, S. A. 1988. What's behind long-term declines in some breeding bird populations? The Passenger Pigeon 50:133-138.

United States Fish and Wildlife Service. 1979. Final environmental impact statement acquisition of lands for the Canaan Valley National Wildlife Refuge West Virginia, United States Department of the Interior.

Vickery, P. D., M. L. Hunter, Jr., and S. M. Melvin. 1994. Effects of habitat area on the distribution of grassland birds in Maine. Conservation Biology 8:1087-1097.

Warren, K. A., and M. R. Ryan. 1999. Do internal fire lanes affect nest depredation rates in prairies? The Prairie Naturalist 31:215-220. 
Wheelwright, N. T., and J. D. Rising. 1993. Savannah sparrow (Passerculus sandwichensis). In The Birds of North America, No. 45 (A. Poole and F. Gill, eds.). The Academy of Natural Sciences, Philadelphia, PA, and The American Ornithologists' Union, Washington, D. C., USA.

Whitmore, R. C. 1978. Reclaimed surface mines as avian habitat islands in the eastern forest. American Birds 34:13-14.

Whitmore, R. C., and G. A. Hall. 1978. The response of passerine species to a new resource: Reclaimed surface mines in West Virginia. American Birds 32:6-9.

Winter, M. 1998. Effect of habitat fragmentation of grassland-nesting birds in southwestern Missouri. Dissertation, University of Missouri-Columbia, Missouri, USA.

Winter, M. 1999. Nesting biology of dickcissels and Henslow's sparrows in southwestern Missouri prairie fragments. Wilson Bulletin 111:515-527.

Wray, T., II. 1979. Breeding biology and reproductive success of three sparrow species on reclaimed surface mines in West Virginia. Thesis, West Virginia University, Morgantown, West Virginia, USA.

Wray, T., II, P. B. Wackenhut, and R. C. Whitmore. 1978. The reproductive biology of passerine birds breeding on reclaimed surface mines in northern West Virginia. Pages 333-344 in D. E. Samuel, J. R. Stauffer, C. H. Hocutt, and W. T. Mason, Jr., editors. Proceeding of Symposium on Surface mining and fish/wildlife needs in the eastern United States. USFWS FWS/OBS-78-81.

Wray, T., II, K. A. Strait, and R. C. Whitmore. 1982. Reproductive success of grassland sparrows on a reclaimed surface mine in West Virginia. Auk 99:157-164. 
Table 1. Five dominant vegetative species (\%) found at bobolink, eastern meadowlark, savannah sparrow, and red-winged blackbird nest sites on the Canaan Valley National Wildlife Refuge, Tucker County, West Virginia, 1999-2000. * Indicates vegetative species is not among the 5 most dominant vegetative species for that particular grassland nesting bird.

\begin{tabular}{llllll}
\hline Scientific Name & Common Name & Bobolink & $\begin{array}{l}\text { Eastern } \\
\text { Meadowlark }\end{array}$ & $\begin{array}{l}\text { Savannah } \\
\text { Sparrow }\end{array}$ & $\begin{array}{l}\text { Red-winged } \\
\text { Blackbird }\end{array}$ \\
\hline Solidago rugosa & $\begin{array}{l}\text { Wrinkle-leaved } \\
\text { goldenrod }\end{array}$ & 9.65 & 5.67 & $*$ & 6.70 \\
Solidago uliginosa & Bog goldenrod & 10.02 & $*$ & $*$ & $*$ \\
$\begin{array}{l}\text { Anthoxanthum } \\
\text { odoratum }\end{array}$ & Sweet vernal grass & 8.62 & $*$ & 5.03 & $*$ \\
$\begin{array}{l}\text { Dactylis glomerata } \\
\text { Danthonia compressa }\end{array}$ & Orchard grass & $*$ & $*$ & 7.28 & $*$ \\
Molium perenne & Quackgrass & $*$ & $*$ & 21.64 & $*$ \\
Phalaris arundinacea & Reed canary grass & 12.35 & 21.20 & $*$ & 3.38 \\
Phleum pratense & Timothy & 8.39 & $*$ & $*$ & 4.93 \\
Lotus corniculatus & Birdsfoot trefoil & $*$ & 5.57 & $*$ & $*$ \\
Fragaria spp. & Wild strawberry & $*$ & $*$ & 4.12 & $*$ \\
Potentilla spp. & Cinquefoil & $*$ & 7.92 & 18.53 & $*$ \\
Spiraea alba & $\begin{array}{l}\text { Narrow-leaved } \\
\text { meadowsweet }\end{array}$ & $*$ & $*$ & $*$ & 57.80 \\
\hline \hline
\end{tabular}


Table 2. Number of nests found per year (percent success/depredation) of nests found on the Canaan Valley National Wildlife Refuge, Canaan Valley, West Virginia for the 1999 and 2000 breeding seasons.

\begin{tabular}{lcccccc}
\hline Species & $\mathrm{n}$ & $1999^{\mathrm{a}}$ & $2000^{\mathrm{a}}$ & Depredated $^{\mathrm{b}}$ & Fledged $^{\mathrm{b}}$ & Abandoned $^{\mathrm{b}}$ \\
\hline Bobolink & 26 & $4(11)$ & $22(26)$ & $9(35)$ & $15(57)$ & $2(08)$ \\
Eastern meadowlark & 11 & $4(11)$ & $7(09)$ & $6(55)$ & $5(45)$ & $0(0)$ \\
Savannah sparrow & 25 & $8(22)$ & $17(20)$ & $11(44)$ & $12(48)$ & $2(08)$ \\
Red-winged blackbird & 21 & $6(16)$ & $15(18)$ & $9(43)$ & $10(48)$ & $2(09)$ \\
Vesper sparrow & 1 & $0(0)$ & $1(01)$ & $0(0)$ & $1(100)$ & $0(0)$ \\
Chipping sparrow & 7 & $5(13)$ & $1(01)$ & $2(33)$ & $3(50)$ & $1(17)$ \\
Common yellowthroat & 2 & $1(01)$ & $1(01)$ & $1(50)$ & $1(50)$ & $0(0)$ \\
Mallard & 1 & $0(0)$ & $1(01)$ & $1(100)$ & $0(0)$ & $0(0)$ \\
Cedar waxwing & 17 & $6(16)$ & $11(13)$ & $6(35)$ & $8(47)$ & $3(18)$ \\
American robin & 9 & $2(05)$ & $7(09)$ & $4(44)$ & $5(56)$ & $0(0)$ \\
Eastern kingbird & 5 & $1(03)$ & $1(01)$ & $0(0)$ & $2(100)$ & $0(0)$ \\
Carolina wren & 1 & $1(03)$ & $0(0)$ & $0(0)$ & $1(100)$ & $0(0)$ \\
\hline \hline
\end{tabular}

\footnotetext{
${ }^{a}$ The number in parentheses indicates the percent of the total number of nests found for all species in that year.

${ }^{\mathrm{b}}$ The number in parentheses indicates the percent of the total number of nests found for a particular species in 1999 and 2000.
} 
Table 3. Average clutch size of nests for grassland species found on the Canaan Valley National Wildlife Refuge, Tucker County, West Virginia 1999-2000.

\begin{tabular}{lccc}
\hline Species & Sample Size & $\overline{\mathrm{x}}$ & $\mathrm{SE}$ \\
\hline Bobolink & 26 & 4.36 & 0.18 \\
Chipping sparrow & 7 & 3.25 & 0.48 \\
Common yellowthroat & 2 & 2.00 & $\cdot$ \\
Eastern meadowlark & 11 & 4.73 & 0.19 \\
Red-winged blackbird & 21 & 3.75 & 0.10 \\
Savannah sparrow & 25 & 3.92 & 0.21 \\
Vesper sparrow & 1 & 2.00 & $\cdot$ \\
\hline \hline
\end{tabular}


Table 4. Number of nests, Mayfield nesting success, and daily survival rates of all grassland birds found on each tract and habitat type on the Canaan Valley National Wildlife Refuge, Tucker County, West Virginia 1999-2000.

\begin{tabular}{|c|c|c|c|c|c|c|c|c|}
\hline \multirow[b]{2}{*}{ Tracts } & \multirow{2}{*}{$\begin{array}{l}\text { Size } \\
\text { (ha) }\end{array}$} & \multirow{2}{*}{$\begin{array}{l}\text { Habitat } \\
\text { Type }\end{array}$} & \multicolumn{2}{|c|}{$\begin{array}{l}\text { Number of } \\
\text { Nests Found }\end{array}$} & \multicolumn{2}{|c|}{ Nest Success } & \multicolumn{2}{|c|}{$\begin{array}{l}\text { Daily Survival } \\
\text { Rates }\end{array}$} \\
\hline & & & 1999 & 2000 & 1999 & 2000 & 1999 & 2000 \\
\hline Beall & 93 & Hayfield & 4 & 12 & 19.65 & 23.93 & 0.927 & 0.942 \\
\hline Cortland & 16 & Pasture & 0 & 0 & . & . & . & . \\
\hline Freeland & 28 & Pasture & 12 & 20 & 0.00 & 34.98 & 0.939 & 0.963 \\
\hline Harper & 73 & Hayfield & 0 & 0 & . & . & . & . \\
\hline Hertz & 61 & Pasture & 2 & 3 & . & . & 0.875 & 0.667 \\
\hline Thompson & 24 & Hayfield & 7 & 22 & 34.33 & 27.98 & 0.937 & 0.960 \\
\hline Reichell $^{\mathrm{a}}$ & & Hayfield & 0 & 1 & . & . & . & 1.00 \\
\hline Cooper $^{a}$ & & Hayfield & 0 & 6 & . & 14.87 & . & 0.946 \\
\hline
\end{tabular}

${ }^{\mathrm{a}}$ Tracts only nest searched in 2000. 
Table 5. Number of nests, exposure days, Mayfield nesting success, daily nest survival of all grassland birds found nesting on each tract and treatment on the Canaan Valley National Wildlife Refuge, Tucker County, West Virginia 1999-2000.

\begin{tabular}{|c|c|c|c|c|c|}
\hline Tracts & Treatment & $\begin{array}{l}\text { Number of } \\
\text { Nests Found }\end{array}$ & Obs.Days & $\begin{array}{l}\text { Nest } \\
\text { Success }\end{array}$ & $\begin{array}{l}\text { Daily Nest } \\
\text { Survival }\end{array}$ \\
\hline Beall & $\begin{array}{l}\text { Mowed } \\
\text { Unmowed }\end{array}$ & $\begin{array}{l}5 \\
11\end{array}$ & $\begin{array}{l}30 \\
74\end{array}$ & $\begin{array}{l}17.624 \\
25.42\end{array}$ & $\begin{array}{l}0.93333 \\
0.94595\end{array}$ \\
\hline Cortland & $\begin{array}{l}\text { Mowed } \\
\text { Unmowed }\end{array}$ & $\begin{array}{l}0 \\
0\end{array}$ & $\begin{array}{l}0 \\
0\end{array}$ & . & . \\
\hline Freeland & $\begin{array}{l}\text { Mowed } \\
\text { Unmowed }\end{array}$ & $\begin{array}{l}15 \\
17\end{array}$ & $\begin{array}{l}189 \\
53\end{array}$ & $\begin{array}{l}48.09 \\
17.62\end{array}$ & $\begin{array}{l}0.97354 \\
0.92453\end{array}$ \\
\hline Harper & $\begin{array}{l}\text { Mowed } \\
\text { Unmowed }\end{array}$ & $\begin{array}{l}0 \\
0\end{array}$ & $\begin{array}{l}0 \\
0\end{array}$ & . & . \\
\hline Hertz & Unmowed & 5 & 3 & . & 0.66667 \\
\hline Thompson & $\begin{array}{l}\text { Mowed } \\
\text { Unmowed }\end{array}$ & $\begin{array}{l}7 \\
22\end{array}$ & $\begin{array}{l}91 \\
132\end{array}$ & $\begin{array}{l}78.43 \\
22.07\end{array}$ & $\begin{array}{l}0.97802 \\
0.94697\end{array}$ \\
\hline Reichell $^{1}$ & Mowed & 1 & 3 & . & 1.00000 \\
\hline Cooper $^{1}$ & Mowed & 6 & 56 & 14.87 & 0.94643 \\
\hline
\end{tabular}


Table 6. Number of active nests, exposure days, Mayfield nesting success, and daily survival rate of bobolinks, eastern meadowlarks, savannah sparrows, and red-winged blackbirds (the most common species found on the grassland portion of the Canaan Valley NWR, Canaan Valley, West Virginia in 1999 and 2000.

\begin{tabular}{|c|c|c|c|c|c|c|c|}
\hline Species & Year & Treatment & Habitat & $\mathrm{n}$ & $\begin{array}{l}\text { Exp. } \\
\text { Days }\end{array}$ & Nest Success & $\begin{array}{l}\text { Daily Survival } \\
\text { Rates }\end{array}$ \\
\hline \multirow[t]{6}{*}{ Bobolink } & 1999 & Unmowed & Pastures & 4 & 17 & 13.48 & 0.882 \\
\hline & 1999 & Unmowed & Hayfields & 0 & 0 & 0 & 0 \\
\hline & 2000 & Mowed & Pastures & 5 & 42 & 20.32 & 0.929 \\
\hline & 2000 & Mowed & Hayfields & 10 & 96 & 37.29 & 0.969 \\
\hline & 2000 & Unmowed & Pastures & 2 & 8 & . & 0.750 \\
\hline & 2000 & Unmowed & Pastures & 5 & 45 & 28.97 & 0.978 \\
\hline \multirow{7}{*}{$\begin{array}{l}\text { Eastern } \\
\text { meadowlark }\end{array}$} & 1999 & Unmowed & Pastures & 2 & 16 & . & 1.00 \\
\hline & & & & & & & \\
\hline & 1999 & Unmowed & Hayfields & 2 & 29 & 1.00 & 0.966 \\
\hline & 2000 & Mowed & Pastures & 1 & 17 & 1.00 & 0.941 \\
\hline & 2000 & Mowed & Hayfields & 2 & 12 & 1.34 & 0.833 \\
\hline & 2000 & Unmowed & Pastures & 1 & 11 & . & 0.909 \\
\hline & 2000 & Unmowed & Hayfields & 3 & 41 & 1.00 & 0.976 \\
\hline \multirow{5}{*}{$\begin{array}{l}\text { Red-winged } \\
\text { Blackbird }\end{array}$} & 1999 & Unmowed & Pastures & 2 & 23 & 0.00 & 0.957 \\
\hline & & & & & & & \\
\hline & 1999 & Unmowed & Hayfields & 4 & 38 & 21.57 & 0.921 \\
\hline & 2000 & Mowed & Pastures & 6 & 120 & 79.93 & 0.992 \\
\hline & 2000 & Mowed & Hayfields & 0 & 0 & 0 & 0 \\
\hline
\end{tabular}


Table 6. Continued.

\begin{tabular}{lcllllll}
\hline Species & Year & Treatment & Habitat & N & $\begin{array}{l}\text { Exp. } \\
\text { Days }\end{array}$ & Nest Success & $\begin{array}{l}\text { Daily Survival } \\
\text { Rates }\end{array}$ \\
& 2000 & Unmowed & Pastures & 3 & 33 & 31.86 & 0.970 \\
& 2000 & Unmowed & Hayfields & 6 & 64 & 3.59 & 0.922 \\
Savannah sparrow & 1999 & Unmowed & Pastures & 3 & 18 & 38.27 & 0.889 \\
& 1999 & Unmowed & Hayfields & 5 & 37 & 26.32 & 0.919 \\
& 2000 & Mowed & Pastures & 2 & 10 &. & 1.00 \\
& 2000 & Mowed & Hayfields & 7 & 72 & 57.22 & 0.972 \\
& 2000 & Unmowed & Pastures & 1 & 4 &. & 0.750 \\
& & Unmowed & Hayfields & 7 & 56 & 16.85 & 0.929 \\
\hline \hline
\end{tabular}


Table 7. Vegetative variables that were different between nest sites and random locations using stepwise discriminant analysis to determine which variables best fit the model on the Canaan Valley National Wildlife Refuge, Tucker County, West Virginia 1999-2000.

\begin{tabular}{|c|c|c|c|c|c|c|}
\hline Species & Variables & Partial $r^{2}$ & $\bar{x}$ & SE & $\bar{x}$ & $\mathrm{SE}$ \\
\hline \multirow[t]{3}{*}{ Bobolink } & Bare Ground (\%) & 0.1516 & 0 & 0 & 4.00 & 1.53 \\
\hline & $\begin{array}{l}\text { Standing Dead Vegetation } \\
(\%)\end{array}$ & 0.0797 & 4.52 & 1.37 & 1.60 & 0.80 \\
\hline & Litter (\%) & 0.0686 & 9.40 & 3.02 & 11.60 & 2.70 \\
\hline \multirow[t]{3}{*}{$\begin{array}{l}\text { Eastern } \\
\text { meadowlark }\end{array}$} & $\begin{array}{l}\text { Standing Dead Vegetation } \\
(\%)\end{array}$ & 0.4324 & 12.00 & 3.46 & 0.82 & 0.05 \\
\hline & Litter Depth $(\mathrm{cm})$ & 0.2511 & 4.45 & 1.06 & 1.00 & 0.30 \\
\hline & Maximum Height $(\mathrm{cm})$ & 0.5061 & 56.36 & 6.94 & 37.00 & 6.64 \\
\hline \multirow{3}{*}{$\begin{array}{l}\text { Red-winged } \\
\text { blackbird }\end{array}$} & Litter $(\%)$ & 0.2464 & 0.75 & 0.55 & 20.00 & 3.42 \\
\hline & Wood $(\%)$ & 0.2276 & 58.90 & 11.05 & 1.55 & 0.82 \\
\hline & Maximum Height $(\mathrm{cm})$ & 0.6264 & 91.70 & 3.23 & 36.65 & 5.05 \\
\hline \multirow[t]{2}{*}{ Savannah sparrow } & Standing dead vegetation $(\%)$ & 0.1298 & 6.92 & 3.02 & 1.20 & 0.60 \\
\hline & Grass (\%) & 0.0702 & 44.24 & 4.61 & 30.60 & 4.59 \\
\hline
\end{tabular}


Table 8. Vegetative variables that were different between successful and unsuccessful nests using stepwise discriminant analysis to determine which variables best fit the model on the Canaan Valley National Wildlife Refuge, Tucker County, West Virginia 19992000.

\begin{tabular}{lllll}
\hline \multirow{2}{*}{ Species } & Variables & Partial $\mathrm{r}^{2}$ & F-value & P-value \\
\hline \multirow{2}{*}{ Bobolink } & Vertical Density $(\mathrm{cm})$ & 0.1544 & 4.20 & 0.0520 \\
Red-winged blackbird & Wood (\%) & 0.1367 & 2.85 & 0.1086 \\
& Maximum Height $(\mathrm{cm})$ & 0.2574 & 5.89 & 0.0266 \\
& Distance to edge & 0.2087 & 4.22 & 0.0566 \\
Savannah sparrow & Maximum Height $(\mathrm{cm})$ & 0.1665 & 4.60 & 0.0429 \\
& Vertical Density $(\mathrm{cm})$ & 0.2083 & 5.79 & 0.0250 \\
\hline
\end{tabular}




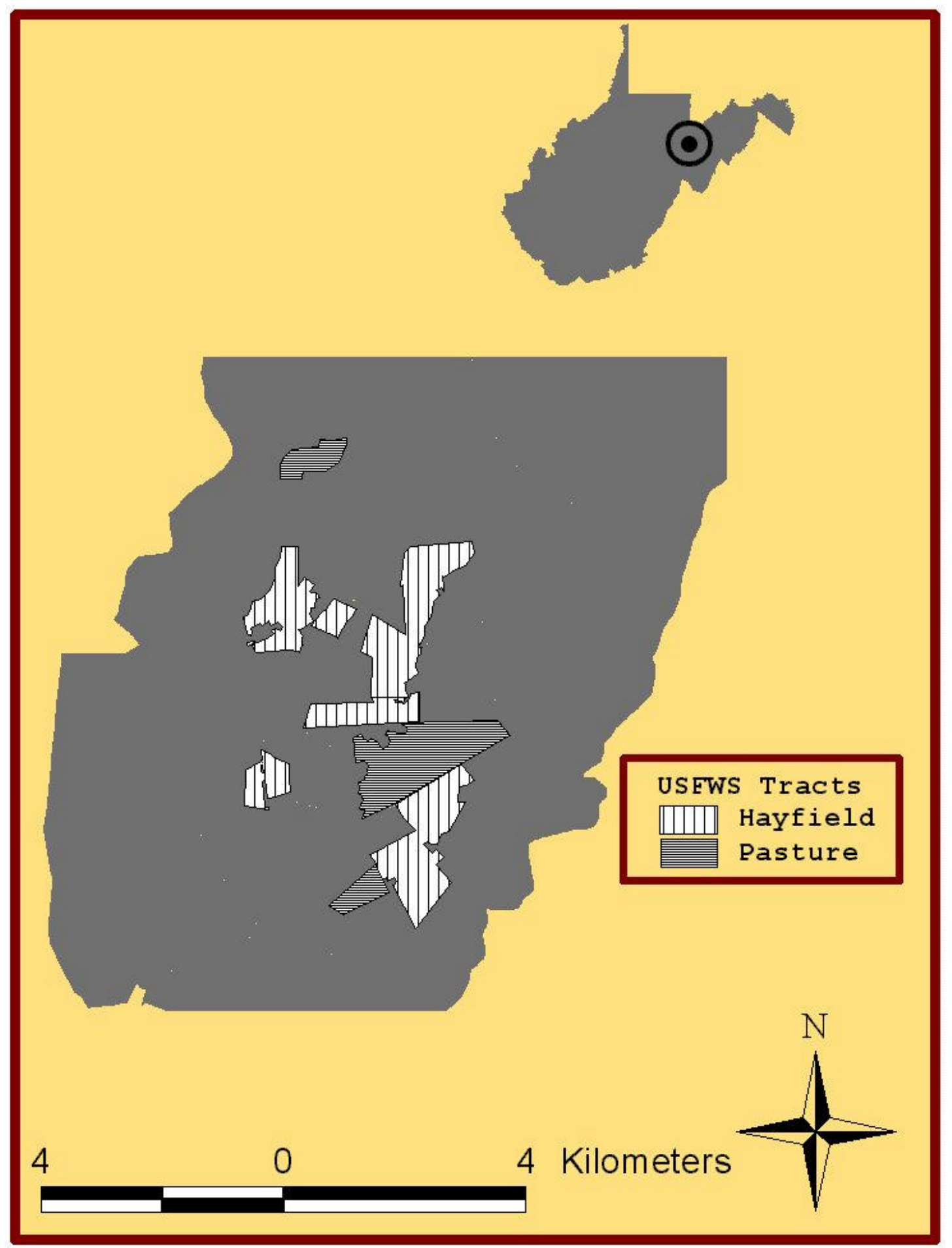

Figure 1. Canaan Valley National Wildlife Refuge grassland study sites in Tucker County, West Virginia for 1999 and 2000. 


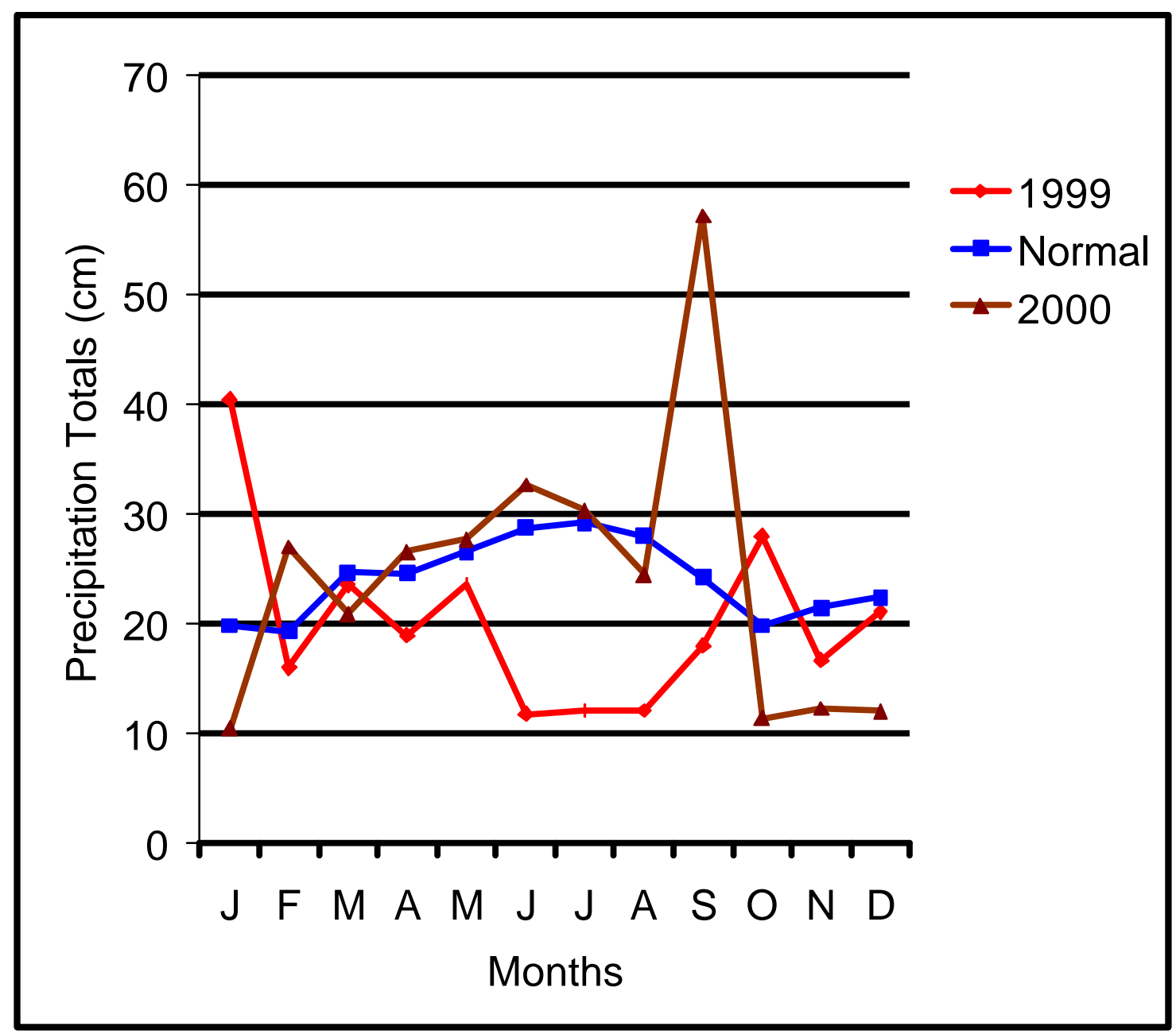

Figure 2. Monthly precipitation totals (cm) for 1999 and 2000, and normal monthly rainfall values for Canaan Valley, Tucker County, West Virginia 1999-2000. 
APPENDIX 
Appendix Ia. Vegetation (\%) (Strausbaugh and Core 1977) found in mowed and unmowed treatments on the Canaan Valley National

Wildlife Refuge, Tucker County, West Virginia 2000.

\begin{tabular}{|c|c|c|c|c|}
\hline Family & Scientific Name & Species & Mowed & Unmowed \\
\hline Apiaceae & Daucus carota & Queen Anne's Lace & 0.08 & 0.36 \\
\hline Apiaceae & Zizia aptera & Golden Alexanders & 0 & 0 \\
\hline Asclepidaceae & Asclepias syriaca & Common Milkweed & 0.06 & 0.10 \\
\hline Asteraceae & Achillea millefolium & Yarrow & 5.78 & 2.56 \\
\hline Asteraceae & Anaphalis margaritacea & Pearly Everlasting & 0 & 0.02 \\
\hline Asteraceae & Aster spp. & Aster & 0.04 & 0.03 \\
\hline Asteraceae & Chrysanthemum leucanthemum & Oxe-eye Daisy & 2.20 & 1.04 \\
\hline Asteraceae & Cirsium spp. & Thistle & 0.15 & 0.22 \\
\hline Asteraceae & Erigeron pulchellus & Dais y Fleabane & 0.14 & 0.07 \\
\hline Asteraceae & Hieracium spp. & Hawkweed & 2.11 & 1.06 \\
\hline Asteraceae & Rudbeckia hirta & Black-eyed Susan & 0.07 & 0.08 \\
\hline Asteraceae & Senecio aureus & Golden Ragwort & 0.01 & 0.08 \\
\hline Asteraceae & Solidago bicolor & Silverrod & 0.01 & 0.02 \\
\hline Asteraceae & Solidago graminifolia & Goldenrod, Grass-leaved & 1.23 & 0.77 \\
\hline
\end{tabular}




\section{Appendix Ia. Continued.}

\begin{tabular}{|c|c|c|c|c|}
\hline Family & Scientific Name & Common Name & Mowed & Unmowed \\
\hline Asteraceae & Solidago rugosa & Goldenrod, Wrinkle-leaved & 8.99 & 5.59 \\
\hline Asteraceae & Solidago uliginosa & Goldenrod, Bog & 5.77 & 11.00 \\
\hline Asteraceae & Tragopogon pratensis & Yellow Goat's Beard & 0.01 & 0.11 \\
\hline Caryophyllaceae & Dianthus armeria & Deptford Pink & 0.01 & 0 \\
\hline Caryophyllaceae & Stellaria graminea & Lesser Stitchwort & 0.75 & 0.14 \\
\hline Caryophyllaceae & Stellaria longifolia & Longleaf Stitchwort & 0.01 & 0 \\
\hline Cruciferae & Brassica rapa & Bird's Rape & 0.01 & $\operatorname{tr}$ \\
\hline Cyperaceae & Carex spp. & Sedge & 0.59 & 1.46 \\
\hline Cyperaceae & Scirpus atrocinctus & Bulrush & 0.01 & 0.05 \\
\hline Ericaceae & Vaccinium spp. & Blueberry & 0.28 & 5.14 \\
\hline Fabaceae & Trifolium agrarium & Clover, Yellow Hop & 0.73 & 0.24 \\
\hline Gentianaceae & Gentiana clausa & Closed Gentian & 0.26 & 0.02 \\
\hline Gramineae & Agrostis alba & Redtop & 4.23 & 1.35 \\
\hline Gramineae & Anthoxanthum odoratum & Sweet Vernal Grass & 7.31 & 4.59 \\
\hline Gramineae & Dactylis glomerata & Orchard Grass & 5.00 & 6.20 \\
\hline
\end{tabular}




\section{Appendix Ia. Continued.}

\begin{tabular}{|c|c|c|c|c|}
\hline Family & Scientific Name & Species & Mowed & Unmowed \\
\hline Gramineae & Festuca eliator & Fescue & 3.20 & 2.07 \\
\hline Gramineae & Holcus lanatus & Velvet Grass & 4.66 & 1.41 \\
\hline Gramineae & Lolium perenne & Eastern Rye Grass & 3.70 & 1.40 \\
\hline Gramineae & Panicum clandestinum & Deertongue & 0.21 & 0.23 \\
\hline Gramineae & Phalaris arundinacea & Reed Canary Grass & 8.76 & 7.18 \\
\hline Gramineae & Phleum pratense & Timothy & 5.39 & 3.18 \\
\hline Hypericaceae & Hypericum densiflorum & Glade St. John's-Wort & 0.33 & 8.44 \\
\hline Hypericaceae & Hypericum ellipticum & Elliptic leaved St. John's-Wort & 0 & 0.02 \\
\hline Juncaceae & Juncus effusus & Common Rush & 0.50 & 2.09 \\
\hline Iridaceae & Sisyrinchium spp. & Blue-eyed Grass & 0.19 & 0.05 \\
\hline Labiatae & Mentha spp. & Mint & 0.09 & 0.07 \\
\hline Labiatae & Prunella vulgaris & Heal-all & 0.77 & 0.17 \\
\hline Labiatae & Satureja vulgaris & Field Basil & 0.49 & 0.16 \\
\hline Labiatae & Stachys palustris & Marsh Woundwort & 0.01 & 0 \\
\hline Leguminosae & Lotus corniculatus & Birdfoot Trefoil & 2.49 & 0 \\
\hline
\end{tabular}


Appendix Ia. Continued.

\begin{tabular}{|c|c|c|c|c|}
\hline Family & Scientific Name & Species & Mowed & Unmowed \\
\hline Leguminosae & Medicago sativa & Alfalfa & 0.01 & $\operatorname{Tr}$ \\
\hline Leguminosae & Trifolium pratense & Clover, Red & 0.76 & 0.56 \\
\hline Leguminosae & Trifolium repens & Clover, White & 0.32 & $\operatorname{Tr}$ \\
\hline Lycopodiaceae & Lycopodium flabelliforme & Groundpine & 0 & 0.13 \\
\hline Lycopodiaceae & Lycopodium spp. & Clubmoss & 1.67 & 2.67 \\
\hline Onagraceae & Oenothera perennis & Small Sundrops & 0.01 & 0.05 \\
\hline Oxalidaceae & Oxalis stricta & European Yellow Wood Sorrel & 0.47 & 0.31 \\
\hline Plantaginaceae & Plantago virginica & Plantain, Buck & 0.14 & 0.07 \\
\hline Polygalaceae & Polygala sanguinea & Rose polygala & 0.35 & 0.08 \\
\hline Polypodiaceae & Pteridium aquilinum & Bracken Fern & 0.02 & 0.54 \\
\hline Polygonaceae & Rumex acetoselia & Field Sorrel, Sheep Sorrel & 0.43 & 0.18 \\
\hline Ranunculaceae & Ranunculus spp. & Buttercup & 1.74 & 0.90 \\
\hline Rosaceae & Crataegus sp. & Hawthorne & 0 & 0.05 \\
\hline Rosaceae & Fragaria spp. & Wild Strawberry & 1.60 & 0.38 \\
\hline Rosaceae & Potentilla spp. & Cinquefoil & 5.98 & 6.11 \\
\hline
\end{tabular}


Appendix Ia. Continued.

\begin{tabular}{|c|c|c|c|c|}
\hline Family & Scientific Name & Species & Mowed & Unmowed \\
\hline Rosaceae & Rubus spp. & Dewberry & 0.88 & 6.01 \\
\hline Rosaceae & Spiraea alba & Narrow-leaved Meadowsweet & 1.23 & 2.87 \\
\hline Rosaceae & Rubus spp. & Blackberry & 0.05 & 0 \\
\hline Rubiaceae & Galium mollugo & Bedstraw, White & 0.04 & 0.92 \\
\hline Rubiaceae & Houstonia caerulea & Bluet & 0.18 & 0.08 \\
\hline Rubiaceae & Taraxacum officinale & Dandelion & 0.48 & 0.64 \\
\hline Salicaceae & Salix sericea & Willow, Silky & 0.27 & 0.55 \\
\hline Scrophulariaceae & Linaria vulgaris & Yellow Toadflax & 0.01 & 0 \\
\hline \multirow[t]{5}{*}{ Violaceae } & Viola papilionacea & Common Blue Violet & 0 & 0.02 \\
\hline & & Litter & 1.65 & 1.12 \\
\hline & & Bare Ground & 0.14 & 0.57 \\
\hline & Polytrichum & Lichen & 0.26 & 2.41 \\
\hline & & Wood & 0 & 0.03 \\
\hline
\end{tabular}


Appendix Ib. Vegetation (\%) (Strausbaugh and Core 1977) found on mowed and unmowed treatments within hayfields and pastures

on the Canaan Valley National Wildlife Refuge, Tucker County, West Virginia 2000.

\begin{tabular}{|c|c|c|c|c|c|c|}
\hline \multirow[b]{2}{*}{ Family } & \multirow[b]{2}{*}{ Scientific Name } & \multirow[b]{2}{*}{ Species } & \multicolumn{2}{|c|}{ Hayfields } & \multicolumn{2}{|c|}{ Pastures } \\
\hline & & & Mowed & Unmowed & Mowed & Unmowed \\
\hline Apiaceae & Daucus carota & Queen Anne's Lace & 0 & 0.54 & 0.49 & 0.13 \\
\hline Apiaceae & Zizia aptera & Golden Alexanders & 0 & 0 & 0 & 0 \\
\hline Asclepidaceae & Asclepias syriaca & Common Milkweed & 0.06 & 0.03 & 0.07 & 0.18 \\
\hline Asteraceae & Achillea millefolium & Yarrow & 6.53 & 4.27 & 1.55 & 0.48 \\
\hline Asteraceae & Anaphalis margaritacea & Pearly Everlasting & 0 & 0.04 & 0 & 0 \\
\hline Asteraceae & Aster spp. & Aster & 0.04 & 0.04 & 0.07 & 0.02 \\
\hline Asteraceae & Chrysanthemum leucanthemum & Oxe-eye Daisy & 2.26 & 1.69 & 1.76 & 0.24 \\
\hline Asteraceae & Cirsium spp. & Thistle & 0.08 & 0.21 & 0.49 & 0.22 \\
\hline Asteraceae & Erigeron pulchellus & Daisy Fleabane & 0.15 & 0.12 & 0.07 & 0 \\
\hline Asteraceae & Rudbeckia hirta & Black-eyed Susan & 0.07 & 0.07 & 0.07 & 0.08 \\
\hline Asteraceae & Hieracium spp. & Hawkweed & 2.23 & 1.00 & 1.34 & 1.08 \\
\hline Asteraceae & Senecio aureus & Golden Ragwort & 0.01 & 0.14 & 0 & 0 \\
\hline Asteraceae & Solidago graminifolia & Goldenrod, Grass-leaved & 1.04 & 0.90 & 2.11 & 0.57 \\
\hline
\end{tabular}


Appendix Ib. Continued.

\begin{tabular}{|c|c|c|c|c|c|c|}
\hline \multirow[b]{2}{*}{ Family } & \multirow[b]{2}{*}{ Scientific Name } & \multirow[b]{2}{*}{ Common Name } & \multicolumn{2}{|c|}{ Hayfields } & \multicolumn{2}{|c|}{ Pastures } \\
\hline & & & Mowed & Unmowed & Mowed & Unmowed \\
\hline Asteraceae & Solidago rugosa & Goldenrod, Wrinkle-leaved & 7.58 & 7.04 & 15.48 & 3.65 \\
\hline Asteraceae & Solidago uliginosa & Goldenrod, Bog & 6.82 & 8.37 & 0 & 13.49 \\
\hline Asteraceae & Tragopogon pratensis & Yellow Goat's Beard & 0.01 & 0.19 & 0 & 0 \\
\hline Caryophyllaceae & Dianthus armeria & Deptford Pink & 0 & 0 & 0.07 & 0 \\
\hline Caryophyllaceae & Stellaria graminea & Lesser Stitchwort & 0.69 & 0.22 & 0.99 & 0.03 \\
\hline Caryophyllaceae & Stellaria longifolia & Longleaf Stitchwort & 0 & 0 & 0.07 & 0 \\
\hline Cruciferae & Brassica rapa & Bird's Rape & 0.01 & 0.01 & 0 & 0 \\
\hline Cyperaceae & Carex spp. & Sedge & 0.44 & 0.71 & 1.27 & 2.26 \\
\hline Cyperaceae & Scirpus atrocinctus & Bulrush & 0.01 & 0.01 & 0 & 0.10 \\
\hline Ericaceae & Vaccinium spp. & Blueberry & 0.33 & 1.68 & 0 & 8.87 \\
\hline Fabaceae & Trifolium agrarium & Clover, Yellow Hop & 0.73 & 0.36 & 0.63 & 0.08 \\
\hline Gentianaceae & Gentiana clausa & Closed Gentian & 0.30 & 0.03 & 0 & 0 \\
\hline Gramineae & Agrostis alba & Redtop & 3.87 & 1.44 & 5.70 & 1.18 \\
\hline Gramineae & Anthoxanthum odoratum & Sweet Vernal Grass & 7.11 & 3.01 & 7.74 & 6.18 \\
\hline Gramineae & Dactylis glomerata & Orchard Grass & 5.56 & 6.81 & 1.76 & 5.19 \\
\hline
\end{tabular}


Appendix Ib. Continued.

\begin{tabular}{|c|c|c|c|c|c|c|}
\hline \multirow[b]{2}{*}{ Family } & \multirow[b]{2}{*}{ Scientific Name } & \multirow[b]{2}{*}{ Species } & \multicolumn{2}{|c|}{ Hayfields } & \multicolumn{2}{|c|}{ Pastures } \\
\hline & & & Mowed & Unmowed & Mowed & Unmowed \\
\hline Gramineae & Danthonia compressa & Allegheny Flyback Grass & 6.30 & 6.94 & 3.80 & 5.34 \\
\hline Gramineae & Festuca eliator & Fescue & 1.63 & 1.36 & 10.91 & 2.79 \\
\hline Gramineae & Holcus lanatus & Velvet Grass & 3.90 & 1.50 & 8.16 & 1.24 \\
\hline Gramineae & Lolium perenne & Eastern Rye Grass & 3.94 & 2.09 & 2.18 & 0.54 \\
\hline Gramineae & Panicum clandestinum & Deertongue & 0.15 & 0.25 & 0.49 & 0.19 \\
\hline Gramineae & Phalaris arundinacea & Reed Canary Grass & 10.35 & 13.12 & 0 & \\
\hline Gramineae & Phleum pratense & Timothy & 4.52 & 3.21 & 9.36 & 2.98 \\
\hline Hypericaceae & Hypericum densiflorum & Glade St. John's-Wort & 0.35 & 5.25 & 0.21 & 11.69 \\
\hline Hypericaceae & Hypericum ellipticum & Elliptic leaved St. John's-Wort & 0 & 0 & 0 & 0.05 \\
\hline Iridaceae & Sisyrinchium spp. & Blue-eyed Grass & 0.06 & 0 & 0.84 & 0.11 \\
\hline Juncaceae & Juncus effusus & Common Rush & 0.53 & 1.55 & 0.35 & 2.61 \\
\hline Labiatae & Mentha spp. & Mint & 0.06 & 0.11 & 0.07 & 0.02 \\
\hline Labiatae & Prunella vulgaris & Heal-all & 0.76 & 0.29 & 0.77 & 0.03 \\
\hline Labiatae & Satureja vulgaris & Field Basil & 0.55 & 0.22 & 0.14 & 0.08 \\
\hline Labiatae & Stachys palustris & Marsh Woundwort & 0 & 0 & 0.07 & 0 \\
\hline
\end{tabular}


Appendix Ib. Continued.

\begin{tabular}{|c|c|c|c|c|c|c|}
\hline \multirow[b]{2}{*}{ Family } & \multirow[b]{2}{*}{ Scientific Name } & \multirow[b]{2}{*}{ Species } & \multicolumn{2}{|c|}{ Hayfields } & \multicolumn{2}{|c|}{ Pastures } \\
\hline & & & Mowed & Unmowed & Mowed & Unmowed \\
\hline Leguminosae & Lotus corniculatus & Birdfoot Trefoil & 0.04 & 0 & 0 & 0 \\
\hline Leguminosae & Medicago sativa & Alfalfa & 0.01 & 0 & 0 & 0.02 \\
\hline Leguminosae & Trifolium repens & Clover, White & 0.12 & 0.01 & 1.27 & 0 \\
\hline Leguminosae & Trifolium pratense & Clover, Red & 0.84 & 1.00 & 0.28 & 0.03 \\
\hline Lycopodiaceae & Lycopodium flabelliforme & Groundpine & 0 & 0.01 & 0 & 0.25 \\
\hline Lycopodiaceae & Lycopodium spp. & Clubmoss & 1.98 & 1.37 & 0 & 4.03 \\
\hline Onagraceae & Oenothera perennis & Small Sundrops & 0 & 0.04 & 0.07 & 0.05 \\
\hline Oxalidaceae & Oxalis stricta & European Yellow Wood Sorrel & 0.40 & 0.24 & 0.77 & 0.38 \\
\hline Plantaginaceae & Plantago virginica & Plantain, Buck & 0.17 & 0.12 & 0 & 0 \\
\hline Polygalaceae & Polygala sanguinea & Rose polygala & 0.40 & 0.14 & 0.07 & 0 \\
\hline Polygonaceae & Rumex acetoselia & Field Sorrel, Sheep Sorrel & 0.50 & 0.17 & 0.07 & 0.19 \\
\hline Polypodiaceae & Pteridium aquilinum & Bracken Fern & 0 & 0.10 & 0.14 & 1.02 \\
\hline Ranunculaceae & Ranunculus spp. & Buttercup & 1.76 & 1.41 & 1.55 & 0.27 \\
\hline Rosaceae & Crataegus sp. & Hawthorne & 0 & 0.08 & 0 & 0.02 \\
\hline Rosaceae & Fragaria spp. & Wild Strawberry & 1.51 & 0.61 & 1.97 & 0.10 \\
\hline
\end{tabular}


Appendix Ib. Continued.

\begin{tabular}{|c|c|c|c|c|c|c|}
\hline \multirow[b]{2}{*}{ Family } & \multirow[b]{2}{*}{ Scientific Name } & \multirow[b]{2}{*}{ Common Name } & \multicolumn{2}{|c|}{ Hayfields } & \multicolumn{2}{|c|}{ Pastures } \\
\hline & & & Mowed & Unmowed & Mowed & Unmowed \\
\hline Rosaceae & Potentilla spp. & Cinquefoil & 5.59 & 9.86 & 7.53 & 1.48 \\
\hline Rosaceae & Rubus spp. & Dewberry & 0.86 & 1.22 & 0.91 & 11.21 \\
\hline Rosaceae & Spiraea alba & Narrow-leaved Meadowsweet & 1.45 & 2.59 & 0 & 3.04 \\
\hline Rosaceae & & Blackberry & 0.01 & 0 & 0.21 & 0.02 \\
\hline Rubiaceae & Galium mollugo & Bedstraw, White & 2.20 & 0.96 & 3.80 & 0.83 \\
\hline Rubiaceae & Houstonia caerulea & Bluet & 0.21 & 0.06 & 0 & 0.10 \\
\hline Rubiaceae & Taraxacum officinale & Dandelion & 0.39 & 0.68 & 0.91 & 0.57 \\
\hline Salicaceae & Salix sericea & Willow, Silky & 0.32 & 1.01 & 0 & 0 \\
\hline Scrophulariaceae & Linaria vulgaris & Yellow Toadflax & 0.01 & 0 & 0 & 0 \\
\hline \multirow[t]{5}{*}{ Violaceae } & Viola papilionacea & Common Blue Violet & 0 & 0.03 & 0 & 0 \\
\hline & & Litter & 1.72 & 1.59 & 1.20 & 0.53 \\
\hline & & Bare Ground & 0.15 & 0.68 & 0.07 & 0.41 \\
\hline & Polytrichum & Lichen & 0.30 & 1.22 & 0 & 3.66 \\
\hline & & Wood & 0 & 0 & 0 & 0.05 \\
\hline
\end{tabular}


Appendix Ic. Vegetation (\%) (Strausbaugh and Core 1977) found on hayfields and pastures on the Canaan Valley National Wildlife

Refuge, Tucker County, West Virginia 1999-2000.

\begin{tabular}{|c|c|c|c|c|c|c|}
\hline \multirow[b]{2}{*}{ Family } & \multirow[b]{2}{*}{ Scientific Name } & \multirow[b]{2}{*}{ Species } & \multicolumn{2}{|c|}{1999} & \multicolumn{2}{|c|}{2000} \\
\hline & & & Hayfields & Pastures & Hayfields & Pastures \\
\hline Apiaceae & Daucus carota & Queen Anne's Lace & 0.34 & 0 & 0.54 & 0.13 \\
\hline Asclepidaceae & Asclepias syriaca & Common Milkweed & 0.05 & 0 & 0.03 & 0.18 \\
\hline Asteraceae & Achillea millefolium & Yarrow & 6.46 & 3.18 & 4.27 & 0.48 \\
\hline Asteraceae & Anaphalis margaritacea & Pearly Everlasting & 0 & 0 & 0.04 & 0 \\
\hline Asteraceae & Aster spp. & Aster & 0.12 & 0.30 & 0.04 & 0.02 \\
\hline \multirow[t]{2}{*}{ Asteraceae } & Chrysanthemum & & 1.46 & 0.22 & 1.69 & 0.24 \\
\hline & leucanthemum & Oxe-eye Daisy & & & & \\
\hline Asteraceae & Cirsium spp. & Thistle & 0.19 & 0.29 & 0.21 & 0.22 \\
\hline Asteraceae & Erigeron pulchellus & Daisy Fleabane & $\operatorname{Tr}$ & 0 & 0.12 & 0 \\
\hline Asteraceae & Hieracium spp. & Hawkweed & 0.15 & 0 & 1.00 & 1.08 \\
\hline Asteraceae & Rudbeckia hirta & Black-eyed Susan & 0.01 & 0.02 & 0.07 & 0.08 \\
\hline Asteraceae & Senecio aureus & Golden Ragwort & 0 & 0.05 & 0.14 & 0 \\
\hline Asteraceae & Solidago bicolor & Silverrod & 0 & 0.01 & 0 & 0.05 \\
\hline
\end{tabular}


Appendix Ic. Continued.

\begin{tabular}{|c|c|c|c|c|c|c|}
\hline \multirow[b]{2}{*}{ Family } & \multirow[b]{2}{*}{ Scientific Name } & \multirow[b]{2}{*}{ Species } & \multicolumn{2}{|c|}{1999} & \multicolumn{2}{|c|}{2000} \\
\hline & & & Hayfields & Pastures & Hayfields & Pastures \\
\hline Asteraceae & Solidago graminifolia & Goldenrod, Grass-leaved & 1.12 & 2.03 & 0.90 & 0.57 \\
\hline Asteraceae & Solidago rugosa & Goldenrod, Wrinkle-leaved & 5.32 & 6.25 & 7.04 & 3.65 \\
\hline Asteraceae & Solidago uliginosa & Goldenrod, Bog & 6.42 & 13.60 & 8.37 & 13.49 \\
\hline Asteraceae & Tragopogon pratensis & Yellow Goat's Beard & 0.04 & 0 & 0.19 & 0 \\
\hline Caryophyllaceae & Dianthus armeria & Deptford Pink & $\operatorname{Tr}$ & 0 & 0 & 0 \\
\hline Caryophyllaceae & Stellaria graminea & Lesser Stitchwort & 0.02 & 0 & 0.22 & 0.03 \\
\hline Caryophyllaceae & Stellaria longifolia & Longleaf Stitchwort & 0 & 0 & 0 & 0 \\
\hline Cruciferae & Brassica rapa & Bird's Rape & 0 & 0 & 0.01 & 0 \\
\hline Cyperaceae & Carex spp. & Sedge & 1.07 & 2.39 & 0.71 & 2.26 \\
\hline Cyperaceae & Scirpus atrocinctus & Bulrush & 0 & 0 & 0.01 & 0.10 \\
\hline Ericaceae & Vaccinium spp. & Blueberry & 1.09 & 1.14 & 1.68 & 8.87 \\
\hline Fabaceae & Trifolium agrarium & Clover, Yellow Hop & 0.38 & 0 & 0.36 & 0.08 \\
\hline Gentianaceae & Gentiana clausa & Closed Gentian & 0 & 0 & 0.03 & 0 \\
\hline Gramineae & Agrostis alba & Redtop & 0.18 & 1.24 & 1.44 & 1.18 \\
\hline Gramineae & Anthoxanthum odoratum & Sweet Vernal Grass & 0.08 & 4.31 & 3.01 & 6.18 \\
\hline
\end{tabular}


Appendix Ic. Continued.

\begin{tabular}{|c|c|c|c|c|c|c|}
\hline \multirow[b]{2}{*}{ Family } & \multirow[b]{2}{*}{ Scientific Name } & \multirow[b]{2}{*}{ Common Name } & \multicolumn{2}{|c|}{1999} & \multicolumn{2}{|c|}{2000} \\
\hline & & & Hayfields & Pastures & Hayfields & Pastures \\
\hline Gramineae & Dactylis glomerata & Orchard Grass & 6.35 & 1.62 & 6.81 & 5.19 \\
\hline Gramineae & Danthonia compressa & Allegheny Flyback Grass & 0.44 & 1.69 & 6.94 & 5.34 \\
\hline Gramineae & Festuca eliator & Fescue & 0 & 0 & 1.36 & 2.79 \\
\hline Gramineae & Holcus lanatus & Velvet Grass & 0.28 & 1.88 & 1.50 & 1.24 \\
\hline Gramineae & Lolium perenne & Eastern Rye Grass & 0.32 & 0.41 & 2.09 & 0.54 \\
\hline Gramineae & Panicum clandestinum & Deertongue & 0 & 0.02 & 0.25 & 0.19 \\
\hline Gramineae & Phalaris arundinacea & Reed Canary Grass & 11.93 & 0 & 13.12 & 0 \\
\hline Gramineae & Phleum pratense & Timothy & 1.99 & 5.84 & 3.21 & 2.98 \\
\hline Gramineae & Poa palustris & Bluegrass & 2.40 & 0.02 & 0 & 0 \\
\hline Gramineae & Bromus spp. & Smooth Brome & 0.20 & 0.20 & 0 & 0 \\
\hline Hypericaceae & Hypericum densiflorum & Glade St. John's-Wort & 4.28 & 10.30 & 5.25 & 11.69 \\
\hline Hypericaceae & Hypericum ellipticum & Elliptic leaved St. John's-Wort & 0 & 0.07 & 0 & 0.05 \\
\hline Iridaceae & Sisyrinchium spp. & Blue-eyed Grass & 0.01 & 0.32 & 0 & 0.11 \\
\hline Juncaceae & Juncus effusus & Common Rush & 0.11 & 0.62 & 1.55 & 2.61 \\
\hline Labiatae & Mentha spp. & Mint & 0.13 & 1.06 & 0.11 & 0.02 \\
\hline
\end{tabular}


Appendix Ic. Continued.

\begin{tabular}{|c|c|c|c|c|c|c|}
\hline \multirow[b]{2}{*}{ Family } & \multirow[b]{2}{*}{ Scientific Name } & \multirow[b]{2}{*}{ Common Name } & \multicolumn{2}{|c|}{1999} & \multicolumn{2}{|c|}{2000} \\
\hline & & & Hayfields & Pastures & Hayfields & Pastures \\
\hline Labiatae & Prunella vulgaris & Heal-all & 0.10 & 0.07 & 0.29 & 0.03 \\
\hline Labiatae & Satureja vulgaris & Field Basil & 0.28 & 0.04 & 0.22 & 0.08 \\
\hline Labiatae & Stachys palustris & Marsh Woundwort & 0 & 0 & 0 & 0 \\
\hline Leguminosae & Lotus corniculatus & Birdfoot Trefoil & 0 & 0 & 0 & 0 \\
\hline Leguminosae & Medicago sativa & Alfalfa & $\operatorname{Tr}$ & 0 & 0 & 0.02 \\
\hline Leguminosae & Trifolium pratense & Clover, Red & 0.68 & 0.07 & 1.00 & 0.03 \\
\hline Leguminosae & Trifolium repens & Clover, White & 0 & 0 & 0.01 & 0 \\
\hline Lycopodiaceae & Lycopodium flabelliforme & Groundpine & 0 & 0.16 & 0.01 & 0.25 \\
\hline Lycopodiaceae & Lycopodium spp. & Clubmoss & 5.48 & 4.56 & 1.37 & 4.03 \\
\hline Onagraceae & Oenothera perennis & Small Sundrops & 0.07 & 0 & 0.04 & 0.05 \\
\hline Oxalidaceae & Oxalis stricta & European Yellow Wood Sorrel & 0.16 & 0.37 & 0.24 & 0.38 \\
\hline Plantaginaceae & Plantago virginica & Plantain, Buck & 0.15 & 0.48 & 0.12 & 0 \\
\hline Polygalaceae & Polygala sanguinea & Rose polygala & 0 & 0 & 0.14 & 0 \\
\hline Polygonaceae & Rumex acetoselia & Field Sorrel, Sheep Sorrel & 0 & 0 & 0.17 & 0.19 \\
\hline Polypodiaceae & Pteridium aquilinum & Bracken Fern & 0.02 & 0.12 & 0.10 & 1.02 \\
\hline Ranunculaceae & Ranunculus spp. & Buttercup & 0.17 & 0.38 & 1.41 & 0.27 \\
\hline
\end{tabular}


Appendix Ic. Continued.

\begin{tabular}{|c|c|c|c|c|c|c|}
\hline \multirow[b]{2}{*}{ Family } & \multirow[b]{2}{*}{ Scientific Name } & \multirow[b]{2}{*}{ Species } & \multicolumn{2}{|c|}{1999} & \multicolumn{2}{|c|}{2000} \\
\hline & & & Hayfields & Pastures & Hayfields & Pastures \\
\hline Rosaceae & Crataegus sp. & Hawthorne & 0 & 0 & 0.08 & 0.02 \\
\hline Rosaceae & Fragaria spp. & Wild Strawberry & 0.33 & 2.34 & 0.61 & 0.10 \\
\hline Rosaceae & Potentilla spp. & Cinquefoil & 11.12 & 4.20 & 9.86 & 1.48 \\
\hline Rosaceae & Rubus spp. & Dewberry & 0.55 & 2.41 & 1.22 & 11.21 \\
\hline Rosaceae & Spiraea alba & Narrow-leaved Meadowsweet & 1.90 & 7.56 & 2.59 & 3.04 \\
\hline Rosaceae & & Blackberry & 0 & 0 & 0 & 0.02 \\
\hline Rubiaceae & Galium mollugo & Bedstraw, White & 3.61 & 2.02 & 0.96 & 0.83 \\
\hline Rubiaceae & Houstonia caerulea & Bluet & 0.08 & 0.26 & 0.06 & 0.10 \\
\hline Rubiaceae & Taraxacum officinale & Dandelion & 0.62 & 1.14 & 0.68 & 0.57 \\
\hline Salicaceae & Salix sericea & Willow, Silky & 0.43 & 0.04 & 1.01 & 0 \\
\hline Scrophulariaceae & Linaria vulgaris & Yellow Toadflax & 0 & 0 & 0 & 0 \\
\hline Violaceae & Viola papilionacea & Common Blue Violet & 0.02 & 0 & 0.03 & 0 \\
\hline \multirow[t]{3}{*}{ Apaciae } & Zizia aptera & Golden Alexander & 0.04 & 0.05 & 0 & 0 \\
\hline & & Litter & 20.66 & 13.55 & 1.59 & 0.53 \\
\hline & & Bare Ground & 0.48 & 1.09 & 0.68 & 0.41 \\
\hline
\end{tabular}


Appendix Ic. Continued.

\begin{tabular}{|c|c|c|c|c|c|c|}
\hline \multirow[b]{2}{*}{ Family } & \multirow[b]{2}{*}{ Scientific Name } & \multirow[b]{2}{*}{ Common Name } & \multicolumn{2}{|c|}{1999} & \multicolumn{2}{|c|}{2000} \\
\hline & & & Hayfields & Pastures & Hayfields & Pastures \\
\hline & Polytrichum & Lichen & 0.09 & 0 & 1.22 & 3.66 \\
\hline & & Wood & 0 & 0 & 0 & 0.05 \\
\hline
\end{tabular}


Appendix II. Maximum number of birds during a weekly bird surveys on 6 grassland plots on the Canaan Valley National Wildlife

Refuge, Tucker County, West Virginia 1999-2000. All scientific and common names of birds follow the nomenclature of the

American Ornithologists' Union (1998).

\begin{tabular}{|c|c|c|c|c|c|c|c|c|c|c|c|c|c|}
\hline \multirow[b]{3}{*}{ Species } & \multirow[b]{3}{*}{ Scientific Name } & \multicolumn{5}{|c|}{1999} & & \multicolumn{5}{|c|}{2000} & \\
\hline & & \multicolumn{3}{|c|}{ Hayfields } & \multicolumn{3}{|c|}{ Pastures } & \multicolumn{3}{|c|}{ Hayfields } & \multicolumn{3}{|c|}{ Pastures } \\
\hline & & Beall & Harper & Thompson & Cortland & Freeland & Hertz & Beall & Harper & Thompson & Cortland & Freeland & Hertz \\
\hline Bobolink & $\begin{array}{l}\text { Dolichonyx } \\
\text { oryzivorus }\end{array}$ & 4 & 0 & 70 & 0 & 145 & 0 & 4 & 8 & 12 & 3 & 29 & 0 \\
\hline $\begin{array}{l}\text { Savannah } \\
\text { sparrow }\end{array}$ & $\begin{array}{l}\text { Passerculus } \\
\text { sandwichensis }\end{array}$ & 11 & 1 & 6 & 3 & 4 & 8 & 7 & 2 & 6 & 2 & 2 & 4 \\
\hline $\begin{array}{l}\text { Eastern } \\
\text { meadowlark }\end{array}$ & Sturnella magna & 21 & 2 & 2 & 0 & 5 & 0 & 7 & 2 & 3 & 0 & 4 & 0 \\
\hline $\begin{array}{l}\text { Red-winged } \\
\text { blackbird }\end{array}$ & $\begin{array}{l}\text { Agelaius } \\
\text { phoeniceus }\end{array}$ & 0 & 3 & 11 & 0 & 5 & 3 & 2 & 7 & 7 & 1 & 4 & 0 \\
\hline $\begin{array}{l}\text { Grasshopper } \\
\text { sparrow }\end{array}$ & $\begin{array}{l}\text { Ammodramus } \\
\text { savannarum }\end{array}$ & 0 & 0 & 0 & 0 & 0 & 0 & 3 & 2 & 0 & 0 & 0 & 0 \\
\hline Vesper sparrow & $\begin{array}{l}\text { Pooecetes } \\
\text { gramineus }\end{array}$ & 0 & 0 & 0 & 0 & 0 & 1 & 0 & 0 & 0 & 0 & 0 & 0 \\
\hline $\begin{array}{l}\text { Chipping } \\
\text { sparrow }\end{array}$ & $\begin{array}{l}\text { Spizella } \\
\text { passerina }\end{array}$ & 0 & 0 & 0 & 0 & 0 & 5 & 0 & 0 & 0 & 1 & 0 & 1 \\
\hline
\end{tabular}


Appendix II. Continued.

\begin{tabular}{|c|c|c|c|c|c|c|c|c|c|c|c|c|c|}
\hline \multirow[b]{3}{*}{ Species } & \multirow[b]{3}{*}{ Scientific Name } & \multicolumn{5}{|c|}{1999} & & \multicolumn{5}{|c|}{2000} & \\
\hline & & \multicolumn{3}{|c|}{ Hayfields } & \multicolumn{3}{|c|}{ Pastures } & \multicolumn{3}{|c|}{ Hayfields } & \multicolumn{3}{|c|}{ Pastures } \\
\hline & & Beall & Harper & Thompson & Cortland & Freeland & Hertz & Beall & Harper & Thompson & Cortland & Freeland & Hertz \\
\hline Field sparrow & Spizella pusilla & 0 & 0 & 0 & 0 & 0 & 1 & 0 & 1 & 0 & 1 & 0 & 0 \\
\hline $\begin{array}{l}\text { Eastern } \\
\text { towhee }\end{array}$ & $\begin{array}{l}\text { Piplio } \\
\text { erythrophthalmus }\end{array}$ & 0 & 0 & 0 & 0 & 0 & 0 & 0 & 0 & 0 & 0 & 0 & 1 \\
\hline Indigo bunting & Passerina cyanea & 0 & 0 & 0 & 1 & 0 & 0 & 0 & 1 & 0 & 0 & 0 & 0 \\
\hline Song sparrow & Melospiza melodia & 0 & 0 & 0 & 0 & 0 & & 0 & 2 & 0 & 1 & 1 & 0 \\
\hline Canada goose & Branta Canadensis & 0 & 0 & 2 & 0 & 0 & 0 & 0 & 0 & 19 & 0 & 0 & 0 \\
\hline Mallard & Anas platyrhynchos & 0 & 0 & 0 & 0 & 0 & 0 & 0 & 0 & 1 & 0 & 0 & 0 \\
\hline Wild turkey & $\begin{array}{l}\text { Meleagris } \\
\text { gallopavo }\end{array}$ & 0 & 0 & 0 & 0 & 0 & 0 & 7 & 0 & 0 & 0 & 0 & 0 \\
\hline $\begin{array}{l}\text { Northern } \\
\text { harrier }\end{array}$ & Circus cyaneus & 0 & 0 & 0 & 0 & 0 & 0 & 1 & 0 & 0 & 0 & 0 & 0 \\
\hline $\begin{array}{l}\text { Ruby-throated } \\
\text { hummingbird }\end{array}$ & $\begin{array}{l}\text { Archilochus } \\
\text { colubris }\end{array}$ & 0 & 0 & 0 & 0 & 0 & 0 & 0 & 0 & 0 & 1 & 0 & 0 \\
\hline
\end{tabular}


Appendix II. Continued.

\begin{tabular}{|c|c|c|c|c|c|c|c|c|c|c|c|c|c|}
\hline \multirow[b]{3}{*}{ Species } & \multirow[b]{3}{*}{ Scientific Name } & \multicolumn{5}{|c|}{1999} & & \multicolumn{6}{|c|}{2000} \\
\hline & & \multicolumn{3}{|c|}{ Hayfields } & \multicolumn{3}{|c|}{ Pastures } & \multicolumn{3}{|c|}{ Hayfields } & \multicolumn{3}{|c|}{ Pastures } \\
\hline & & Beall & Harper & Thompson & Cortland & Freeland & Hertz & Beall & Harper & Thompson & Cortland & Freeland & Hertz \\
\hline Northern Flicker & Colaptes auratus & 0 & 0 & 2 & 0 & 0 & 2 & 2 & 0 & 0 & 1 & 0 & 0 \\
\hline American crow & $\begin{array}{l}\text { Corvus } \\
\text { brachyrhynchos }\end{array}$ & 0 & 0 & 0 & 0 & 0 & 0 & 0 & 0 & 0 & 1 & 0 & 0 \\
\hline Carolina wren & $\begin{array}{l}\text { Thryothorus } \\
\text { ludovicianus }\end{array}$ & 0 & 0 & 0 & & 0 & 2 & 0 & 0 & 0 & 1 & 0 & 0 \\
\hline Gray catbird & $\begin{array}{l}\text { Dumetella } \\
\text { carolinensis }\end{array}$ & 0 & 0 & 0 & 0 & 0 & 0 & 0 & 0 & 0 & 2 & 0 & 0 \\
\hline Eastern bluebird & Sialia sialis & 0 & 0 & 0 & 0 & 0 & 0 & 0 & 0 & 0 & 1 & 0 & 0 \\
\hline American robin & $\begin{array}{l}\text { Turdus } \\
\text { migratorius }\end{array}$ & 0 & 0 & 0 & 0 & 0 & 0 & 1 & 0 & 0 & 0 & 0 & 0 \\
\hline Cedar waxwing & $\begin{array}{l}\text { Bombycilla } \\
\text { cedrorum }\end{array}$ & 0 & 0 & 0 & 0 & 0 & 0 & 0 & 2 & 0 & 0 & 0 & 0 \\
\hline Red-eyed vireo & Vireo olivaceus & 0 & 0 & 0 & 0 & 0 & 0 & 0 & 0 & 0 & 1 & 0 & 0 \\
\hline $\begin{array}{l}\text { Common } \\
\text { yellowthroat }\end{array}$ & $\begin{array}{l}\text { Geothlypis } \\
\text { trichas }\end{array}$ & 0 & 0 & 3 & 1 & 0 & 4 & 0 & 0 & 1 & 1 & 1 & 1 \\
\hline $\begin{array}{l}\text { American } \\
\text { goldfinch }\end{array}$ & Carduelis tristis & 0 & 0 & 0 & 1 & 0 & 1 & 0 & 0 & 0 & 1 & 0 & 0 \\
\hline
\end{tabular}


Appendix II. Continued.

\begin{tabular}{|c|c|c|c|c|c|c|c|c|c|c|c|c|c|}
\hline \multirow[b]{3}{*}{ Species } & \multirow[b]{3}{*}{ Scientific Name } & \multicolumn{5}{|c|}{1999} & & \multicolumn{5}{|c|}{2000} & \\
\hline & & \multicolumn{3}{|c|}{ Hayfields } & \multicolumn{3}{|c|}{ Pastures } & \multicolumn{3}{|c|}{ Hayfields } & \multicolumn{3}{|c|}{ Pastures } \\
\hline & & Beall & Harper & Thompson & Cortland & Freeland & Hertz & Beall & Harper & Thompson & Cortland & Freeland & Hertz \\
\hline $\begin{array}{l}\text { Northern } \\
\text { cardinal }\end{array}$ & $\begin{array}{l}\text { Cardinalis } \\
\text { cardinalis }\end{array}$ & 0 & 0 & 0 & 0 & 0 & 0 & 0 & 0 & 0 & 1 & 0 & 0 \\
\hline Turkey vulture & Cathartes aura & 0 & 0 & 0 & 0 & 0 & 0 & 0 & 0 & 0 & 0 & 0 & 4 \\
\hline
\end{tabular}


Appendix IIIa. Breeding grassland bird density (number/ha), diversity, and richness by treatment and month for hayfields on the

Canaan Valley National Wildlife Refuge, Tucker County, West Virginia 2000.

\begin{tabular}{|c|c|c|c|c|c|c|c|c|c|c|c|c|c|c|c|c|c|c|}
\hline \multirow[b]{3}{*}{ Species } & \multicolumn{8}{|c|}{ Mowed } & \multicolumn{8}{|c|}{ Unmowed } & \multicolumn{2}{|c|}{$\underline{3-w a y ~ i n t e r a c t i o n ~}^{a}$} \\
\hline & \multicolumn{2}{|c|}{ May } & \multicolumn{2}{|c|}{ June } & \multicolumn{2}{|c|}{ July } & \multicolumn{2}{|c|}{ August } & \multicolumn{2}{|c|}{ May } & \multicolumn{2}{|c|}{ June } & \multicolumn{2}{|c|}{ July } & \multicolumn{2}{|c|}{ August } & \multirow[t]{2}{*}{$F$-value } & \multirow[t]{2}{*}{$P$-value } \\
\hline & $\bar{x}$ & SE & $\bar{x}$ & SE & $\overline{\mathrm{x}}$ & SE & $\bar{x}$ & SE & $\bar{x}$ & SE & $\bar{x}$ & SE & $\bar{x}$ & SE & $\bar{x}$ & SE & & \\
\hline Overall & 0.67 & 0.31 & 0.87 & 0.24 & 1.43 & 0.66 & 0.43 & 0.28 & 1.15 & 0.47 & 1.28 & 0.55 & 2.22 & 0.17 & 1.52 & 0.78 & 0.16 & 0.920 \\
\hline Bobolink & 0.22 & 0.20 & 0.18 & 0.13 & 0.36 & 0.24 & 0 & 0 & 0.10 & 0.08 & 0.18 & 0.18 & 0.52 & 0.26 & 0.34 & 0.29 & 0.41 & 0.747 \\
\hline $\begin{array}{l}\text { Eastern } \\
\text { meadowlark }\end{array}$ & 0.20 & 0.09 & 0.22 & 0.13 & 0.19 & 0.11 & 0.34 & 0.24 & 0.19 & 0.04 & 0.08 & 0.05 & 0.34 & 0.22 & 0.28 & 0.19 & 0.33 & 0.804 \\
\hline $\begin{array}{l}\text { Savannah } \\
\text { sparrow }\end{array}$ & 0.16 & 0.04 & 0.29 & 0.17 & 0.38 & 0.20 & 0.10 & 0.05 & 0.36 & 0.16 & 0.32 & 0.16 & 0.55 & 0.15 & 0.48 & 0.24 & 0.35 & 0.793 \\
\hline Diversity & 0.40 & 0.07 & 0.34 & 0.17 & 0.53 & 0.04 & 0.15 & 0.08 & 0.51 & 0.12 & 0.48 & 0.10 & 0.56 & 0.06 & 0.31 & 0.16 & 0.13 & 0.941 \\
\hline Richness & 0.81 & 0.15 & 0.50 & 0.25 & 1.04 & 0.26 & 0.29 & 0.15 & 0.93 & 0.10 & 0.92 & 0.10 & 1.18 & 0.19 & 0.61 & 0.15 & 0.08 & 0.969 \\
\hline
\end{tabular}

${ }^{\mathrm{a}}$ Results of treatments ${ }^{\mathrm{x}}$ habitat types ${ }^{\mathrm{x}}$ month interactions $(\mathrm{df}=3,28)$. 
Appendix IIIb. Breeding grassland bird density (number/ha), diversity, and richness by treatment and month for pastures on the

Canaan Valley National Wildlife Refuge, Tucker County, West Virginia 2000.

\begin{tabular}{|c|c|c|c|c|c|c|c|c|c|c|c|c|c|c|c|c|c|c|}
\hline \multirow[b]{3}{*}{ Species } & \multicolumn{8}{|c|}{ Mowed } & \multicolumn{8}{|c|}{ Unmowed } & \multicolumn{2}{|c|}{$\underline{\text { 3-way interaction }}{ }^{\mathrm{a}}$} \\
\hline & \multicolumn{2}{|c|}{ May } & \multicolumn{2}{|c|}{ June } & \multicolumn{2}{|c|}{ July } & \multicolumn{2}{|c|}{ August } & \multicolumn{2}{|c|}{ May } & \multicolumn{2}{|c|}{ June } & \multicolumn{2}{|c|}{ July } & \multicolumn{2}{|c|}{ August } & \multirow{2}{*}{$F$-value } & \multirow{2}{*}{$P$-value } \\
\hline & $\bar{x}$ & SE & $\bar{x}$ & SE & $\bar{x}$ & SE & $\bar{x}$ & SE & $\bar{x}$ & SE & $\bar{x}$ & SE & $\bar{x}$ & SE & $\overline{\mathrm{x}}$ & SE & & \\
\hline Overall & 1.38 & 0.28 & 1.92 & 0.55 & 2.23 & 0.10 & 0.76 & 0.49 & 0.60 & 0.45 & 2.03 & 1.07 & 2.81 & 2.17 & 0.38 & 0.31 & 0.16 & 0.920 \\
\hline Bobolink & 0.37 & 0.37 & 0.43 & 0.43 & 0.80 & 0.67 & 0.13 & 0.13 & 0.43 & 0.43 & 1.23 & 1.23 & 2.37 & 2.37 & 0.17 & 0.17 & 0.41 & 0.747 \\
\hline $\begin{array}{l}\text { Eastern } \\
\text { meadowlark }\end{array}$ & 0.19 & 0.19 & 0.23 & 0.23 & 0.07 & 0.07 & 0 & 0 & 0 & 0 & 0.13 & 0.13 & 0 & 0 & 0 & 0 & 0.33 & 0.804 \\
\hline $\begin{array}{l}\text { Savannah } \\
\text { sparrow }\end{array}$ & 0.11 & 0.11 & 0.20 & 0.07 & 0 & 0 & 0 & 0 & 0.08 & 0.01 & 0.42 & 0.26 & 0.35 & 0.18 & 0.21 & 0.15 & 0.35 & 0.793 \\
\hline Diversity & 0.74 & 0.17 & 0.70 & 0.12 & 0.63 & 0.32 & 0.37 & 0.09 & 0.37 & 0.08 & 0.42 & 0.08 & 0.39 & 0.14 & 0.10 & 0.10 & 0.13 & 0.941 \\
\hline Richness & 1.69 & 0.63 & 1.55 & 0.48 & 1.70 & 0.90 & 0.70 & 0.17 & 1.12 & 0.19 & 1.62 & 0.38 & 1.48 & 0.02 & 0.60 & 0.21 & 0.08 & 0.969 \\
\hline
\end{tabular}

${ }^{a}$ Results of treatments ${ }^{\mathrm{x}}$ habitat types ${ }^{\mathrm{x}}$ month interactions $(\mathrm{df}=3,28)$. 
Appendix IIIc. Breeding grassland bird density (number/ha), diversity, and richness by month for hayfields and pastures on the

Canaan Valley National Wildlife Refuge, Tucker County, West Virginia, 2000.

\begin{tabular}{|c|c|c|c|c|c|c|c|c|c|c|c|c|c|c|c|c|c|c|}
\hline \multirow[b]{3}{*}{ Species } & \multicolumn{8}{|c|}{ Hayfields } & \multicolumn{8}{|c|}{ Pastures } & \multicolumn{2}{|c|}{ 2-way interaction ${ }^{\mathrm{a}}$} \\
\hline & \multicolumn{2}{|c|}{ May } & \multicolumn{2}{|c|}{ June } & \multicolumn{2}{|c|}{ July } & \multicolumn{2}{|c|}{ August } & \multicolumn{2}{|c|}{ May } & \multicolumn{2}{|c|}{ June } & \multicolumn{2}{|c|}{ July } & \multicolumn{2}{|c|}{ August } & \multirow[t]{2}{*}{$F$-value } & \multirow[t]{2}{*}{$P$-value } \\
\hline & $\bar{x}$ & SE & $\bar{x}$ & $\mathrm{SE}$ & $\bar{x}$ & SE & $\bar{x}$ & SE & $\bar{x}$ & SE & $\bar{x}$ & $\mathrm{SE}$ & $\bar{x}$ & SE & $\bar{x}$ & SE & & \\
\hline Overall & 0.91 & 0.27 & 1.08 & 0.28 & 1.82 & 0.35 & 0.98 & 0.44 & 0.91 & 0.32 & 1.98 & 0.61 & 2.58 & 1.20 & 0.53 & 0.25 & 0.77 & 0.520 \\
\hline Bobolink & 0.16 & 0.10 & 0.18 & 0.10 & 0.44 & 0.16 & 0.17 & 0.15 & 0.41 & 0.27 & 0.92 & 0.67 & 1.74 & 1.37 & 0.15 & 0.10 & 0.29 & 0.835 \\
\hline $\begin{array}{l}\text { Eastern } \\
\text { meadowlark }\end{array}$ & 0.19 & 0.05 & 0.15 & 0.07 & 0.26 & 0.12 & 0.31 & 0.14 & 0.07 & 0.07 & 0.17 & 0.10 & 0.03 & 0.03 & 0 & 0 & 1.07 & 0.970 \\
\hline $\begin{array}{l}\text { Savannah } \\
\text { sparrow }\end{array}$ & 0.26 & 0.09 & 0.30 & 0.11 & 0.46 & 0.12 & 0.29 & 0.14 & 0.09 & 0.04 & 0.33 & 0.15 & 0.21 & 0.13 & 0.13 & 0.10 & 0.87 & 0.469 \\
\hline Diversity & 0.46 & 0.07 & 0.41 & 0.09 & 0.54 & 0.03 & 0.23 & 0.09 & 0.52 & 0.11 & 0.54 & 0.09 & 0.49 & 0.14 & 0.21 & 0.09 & 0.43 & 0.731 \\
\hline Richness & 0.87 & 0.09 & 0.71 & 0.15 & 1.11 & 0.15 & 0.45 & 0.12 & 1.35 & 0.26 & 1.59 & 0.26 & 1.57 & 0.29 & 0.64 & 0.13 & 1.01 & 0.401 \\
\hline
\end{tabular}

${ }^{\mathrm{a}}$ Results of habitat type ${ }^{\mathrm{x}}$ month interactions $(\mathrm{df}=3,28)$. 
Appendix IIId. Breeding grassland bird density (number/ha), diversity, and richness by month for mowed and unmowed treatments on the Canaan Valley National Wildlife Refuge, Tucker County, West Virginia 2000.

\begin{tabular}{|c|c|c|c|c|c|c|c|c|c|c|c|c|c|c|c|c|c|c|}
\hline \multirow[b]{3}{*}{ Species } & \multicolumn{8}{|c|}{ Mowed } & \multicolumn{8}{|c|}{ Unmowed } & \multicolumn{2}{|c|}{$\underline{\text { 2-way interaction }}{ }^{\mathrm{a}}$} \\
\hline & \multicolumn{2}{|c|}{ May } & \multicolumn{2}{|c|}{ June } & \multicolumn{2}{|c|}{ July } & \multicolumn{2}{|c|}{ August } & \multicolumn{2}{|c|}{ May } & \multicolumn{2}{|c|}{ June } & \multicolumn{2}{|c|}{ July } & \multicolumn{2}{|c|}{ August } & \multirow[t]{2}{*}{$F$-value } & \multirow[t]{2}{*}{$P$-value } \\
\hline & $\overline{\mathrm{x}}$ & SE & $\bar{x}$ & SE & $\bar{x}$ & SE & $\bar{x}$ & SE & $\bar{x}$ & SE & $\overline{\mathrm{x}}$ & SE & $\overline{\mathrm{x}}$ & SE & $\overline{\mathrm{x}}$ & SE & & \\
\hline Overall & 0.67 & 0.31 & 0.87 & 0.24 & 1.43 & 0.66 & 0.43 & 0.28 & 1.38 & 0.28 & 1.92 & 0.55 & 2.23 & 0.10 & 0.76 & 0.49 & 0.11 & 0.953 \\
\hline Bobolink & 0.28 & 0.17 & 0.28 & 0.17 & 0.54 & 0.27 & 0.05 & 0.05 & 0.27 & 0.21 & 0.71 & 0.56 & 1.45 & 1.15 & 0.25 & 0.15 & 0.32 & 0.814 \\
\hline $\begin{array}{l}\text { Eastern } \\
\text { meadowlark }\end{array}$ & 0.20 & 0.08 & 0.23 & 0.10 & 0.14 & 0.07 & 0.20 & 0.15 & 0.09 & 0.05 & 0.10 & 0.06 & 0.17 & 0.13 & 0.14 & 0.11 & 0.08 & 0.970 \\
\hline $\begin{array}{l}\text { Savannah } \\
\text { sparrow }\end{array}$ & 0.14 & 0.04 & 0.25 & 0.10 & 0.23 & 0.14 & 0.06 & 0.04 & 0.22 & 0.10 & 0.37 & 0.14 & 0.45 & 0.11 & 0.35 & 0.14 & 0.66 & 0.584 \\
\hline Diversity & 0.54 & 0.10 & 0.49 & 0.14 & 0.57 & 0.11 & 0.23 & 0.08 & 0.44 & 0.07 & 0.45 & 0.06 & 0.48 & 0.08 & 0.20 & 0.10 & 0.09 & 0.963 \\
\hline Richness & 1.16 & 0.30 & 0.92 & 0.33 & 1.31 & 0.36 & 0.46 & 0.14 & 1.03 & 0.11 & 1.27 & 0.24 & 1.33 & 0.11 & 0.60 & 0.11 & 0.56 & 0.645 \\
\hline
\end{tabular}

\footnotetext{
${ }^{\mathrm{a}}$ Results of treatment ${ }^{\mathrm{x}}$ month interactions $(\mathrm{df}=3,28)$.
} 
Appendix IIIe. Breeding grassland bird density (number/ha), diversity, and richness by habitat types and month for 1999 on the

Canaan Valley National Wildlife Refuge, Tucker County, West Virginia 1999-2000.

\begin{tabular}{|c|c|c|c|c|c|c|c|c|c|c|c|c|c|c|c|c|c|c|}
\hline \multirow[b]{3}{*}{ Species } & \multicolumn{8}{|c|}{ Hayfields } & \multicolumn{8}{|c|}{ Pastures } & \multicolumn{2}{|c|}{$\underline{3 \text {-way interaction }}{ }^{\mathrm{a}}$} \\
\hline & \multicolumn{2}{|c|}{ May } & \multicolumn{2}{|c|}{ June } & \multicolumn{2}{|c|}{ July } & \multicolumn{2}{|c|}{ August } & \multicolumn{2}{|c|}{ May } & \multicolumn{2}{|c|}{ June } & \multicolumn{2}{|c|}{ July } & \multicolumn{2}{|c|}{ August } & \multirow{2}{*}{$\begin{array}{c}F- \\
\text { value }\end{array}$} & \multirow{2}{*}{$\begin{array}{c}P- \\
\text { value }\end{array}$} \\
\hline & $\bar{x}$ & SE & $\bar{x}$ & $\mathrm{SE}$ & $\bar{x}$ & $\mathrm{SE}$ & $\bar{x}$ & $\mathrm{SE}$ & $\bar{x}$ & $\mathrm{SE}$ & $\bar{x}$ & $\mathrm{SE}$ & $\bar{x}$ & SE & $\bar{x}$ & SE & & \\
\hline Overall & 1.91 & 0.71 & 5.20 & 1.27 & 9.00 & 3.80 & 6.67 & 6.67 & 2.35 & 0.79 & 5.68 & 2.18 & 20.28 & 14.28 & 14.92 & 14.23 & 0.54 & 0.657 \\
\hline Bobolink & 0.20 & 0.20 & 0.14 & 0.14 & 1.00 & 0.95 & 3.33 & 3.33 & 0.42 & 0.42 & 0.46 & 0.46 & 3.89 & 3.89 & 7.02 & 7.02 & 0.10 & 0.960 \\
\hline $\begin{array}{l}\text { Eastern } \\
\text { meadowlark }\end{array}$ & 0.43 & 0.36 & 0.41 & 0.15 & 0.44 & 0.23 & 0 & 0 & 0.11 & 0.11 & 0.07 & 0.07 & 0.05 & 0.05 & 0.25 & 0.25 & 1.71 & 0.185 \\
\hline $\begin{array}{l}\text { Savannah } \\
\text { sparrow }\end{array}$ & 0.44 & 0.15 & 0.46 & 0.20 & 0.42 & 0.19 & 0.02 & 0.02 & 0.27 & 0.27 & 0.69 & 0.24 & 0.09 & 0.06 & 0.07 & 0.07 & 0.27 & 0.849 \\
\hline Diversity & 0.37 & 0.12 & 0.41 & 0.11 & 0.30 & 0.02 & 0.03 & 0.03 & 0.33 & 0.17 & 0.43 & 0.22 & 0.39 & 0.12 & 0.04 & 0.04 & 0.13 & 0.940 \\
\hline Richness & 0.70 & 0.25 & 0.89 & 0.43 & 0.70 & 0.25 & 0.18 & 0.12 & 0.74 & 0.06 & 1.08 & 0.26 & 1.35 & 0.53 & 0.28 & 0.19 & 0.36 & 0.782 \\
\hline
\end{tabular}

${ }^{a}$ Results of years ${ }^{x}$ habitat types ${ }^{x}$ month interactions $(\mathrm{df}=3,28)$ 
Appendix IIIf. Breeding grassland bird density (number/ha), diversity, and richness by habitat types and month for 2000 unmowed treatments on the Canaan Valley National Wildlife Refuge, Tucker County, West Virginia 1999-2000.

\begin{tabular}{|c|c|c|c|c|c|c|c|c|c|c|c|c|c|c|c|c|c|c|}
\hline \multirow[b]{3}{*}{ Species } & \multicolumn{8}{|c|}{ Hayfields } & \multicolumn{8}{|c|}{ Pastures } & \multicolumn{2}{|c|}{$\begin{array}{c}\text { 3-way } \\
\text { interaction }^{\mathrm{a}}\end{array}$} \\
\hline & \multicolumn{2}{|c|}{ May } & \multicolumn{2}{|c|}{ June } & \multicolumn{2}{|c|}{ July } & \multicolumn{2}{|c|}{ August } & \multicolumn{2}{|c|}{ May } & \multicolumn{2}{|c|}{ June } & \multicolumn{2}{|c|}{ July } & \multicolumn{2}{|c|}{ August } & \multirow{2}{*}{$\begin{array}{c}F- \\
\text { value }\end{array}$} & \multirow[t]{2}{*}{$P$-value } \\
\hline & $\bar{x}$ & SE & $\bar{x}$ & SE & $\bar{x}$ & $\mathrm{SE}$ & $\bar{x}$ & SE & $\bar{x}$ & SE & $\bar{x}$ & SE & $\bar{x}$ & SE & $\bar{x}$ & SE & & \\
\hline Overall & 1.15 & 0.47 & 1.28 & 0.55 & 2.22 & 0.17 & 1.52 & 0.78 & 0.60 & 0.45 & 2.03 & 1.07 & 2.81 & 2.17 & 0.38 & 0.31 & 0.54 & 0.657 \\
\hline Bobolink & 0.10 & 0.08 & 0.18 & 0.18 & 0.52 & 0.26 & 0.34 & 0.29 & 0.43 & 0.43 & 1.24 & 1.13 & 2.37 & 2.37 & 0.17 & 0.17 & 0.10 & 0.960 \\
\hline $\begin{array}{l}\text { Eastern } \\
\text { meadowlark }\end{array}$ & 0.19 & 0.05 & 0.15 & 0.07 & 0.26 & 0.12 & 0.31 & 0.14 & 0.07 & 0.07 & 0.17 & 0.10 & 0.03 & 0.03 & 0 & 0 & 1.71 & 0.185 \\
\hline $\begin{array}{l}\text { Savannah } \\
\text { sparrow }\end{array}$ & 0.36 & 0.16 & 0.32 & 0.16 & 0.55 & 0.15 & 0.48 & 0.24 & 0.08 & 0.01 & 0.42 & 0.26 & 0.35 & 0.18 & 0.21 & 0.15 & 0.27 & 0.849 \\
\hline Diversity & 0.46 & 0.07 & 0.41 & 0.09 & 0.54 & 0.03 & 0.23 & 0.09 & 0.52 & 0.11 & 0.54 & 0.09 & 0.49 & 0.14 & 0.21 & 0.09 & 0.13 & 0.940 \\
\hline Richness & 0.87 & 0.09 & 0.71 & 0.15 & 1.11 & 0.15 & 0.45 & 0.12 & 1.35 & 0.26 & 1.59 & 0.26 & 1.57 & 0.29 & 0.64 & 0.13 & 0.36 & 0.782 \\
\hline
\end{tabular}

${ }^{a}$ Results of years ${ }^{x}$ habitat types ${ }^{x}$ month interactions $(\mathrm{df}=3,28)$. 
Appendix IIIg. Breeding grassland bird density (number/ha), diversity, and richness by habitat types and month for 1999 and 2000 on the Canaan Valley National Wildlife Refuge, Tucker County, West Virginia, May-August 1999-2000.

\begin{tabular}{|c|c|c|c|c|c|c|c|c|c|c|c|c|c|c|c|c|c|c|}
\hline \multirow[b]{4}{*}{ Species } & \multicolumn{8}{|c|}{1999} & \multicolumn{8}{|c|}{2000} & \multirow{2}{*}{\multicolumn{2}{|c|}{ 2-way interaction ${ }^{\text {a }}$}} \\
\hline & \multirow{2}{*}{\multicolumn{2}{|c|}{ May }} & \multirow{2}{*}{\multicolumn{2}{|c|}{ June }} & \multirow{2}{*}{\multicolumn{2}{|c|}{ July }} & \multirow{2}{*}{\multicolumn{2}{|c|}{ August }} & \multirow{2}{*}{\multicolumn{2}{|c|}{ May }} & \multirow{2}{*}{\multicolumn{2}{|c|}{ June }} & \multirow{2}{*}{\multicolumn{2}{|c|}{ July }} & \multirow{2}{*}{\multicolumn{2}{|c|}{ August }} & & \\
\hline & & & & & & & & & & & & & & & & & \multirow[t]{2}{*}{ F-value } & \multirow{2}{*}{$\begin{array}{c}\mathrm{P}- \\
\text { value }\end{array}$} \\
\hline & $\overline{\mathrm{x}}$ & SE & $\bar{x}$ & $\mathrm{SE}$ & $\bar{x}$ & $\mathrm{SE}$ & $\bar{x}$ & SE & $\overline{\mathrm{x}}$ & $\mathrm{SE}$ & $\bar{x}$ & SE & $\bar{x}$ & SE & $\bar{x}$ & SE & & \\
\hline Overall & 2.13 & 0.49 & 5.44 & 1.13 & 14.64 & 7.07 & 10.79 & 7.27 & 1.65 & 0.56 & 1.65 & 0.56 & 2.52 & 0.98 & 0.95 & 0.45 & 0.50 & 0.683 \\
\hline Bobolink & 0.31 & 0.21 & 0.30 & 0.23 & 2.45 & 1.91 & 5.18 & 3.57 & 0.27 & 0.21 & 0.71 & 0.56 & 1.45 & 1.15 & 0.25 & 0.16 & 0.05 & 0.983 \\
\hline $\begin{array}{l}\text { Eastern } \\
\text { meadowlark }\end{array}$ & 0.27 & 0.18 & 0.24 & 0.11 & 0.25 & 0.14 & 0.12 & 0.12 & 0.04 & 0.04 & 0.16 & 0.06 & 0.15 & 0.07 & 0.17 & 0.09 & 0.34 & 0.796 \\
\hline $\begin{array}{l}\text { Savannah } \\
\text { sparrow }\end{array}$ & 0.35 & 0.14 & 0.57 & 0.15 & 0.25 & 0.12 & 0.05 & 0.03 & 0.22 & 0.10 & 0.37 & 0.14 & 0.45 & 0.11 & 0.35 & 0.14 & 1.84 & 0.160 \\
\hline Diversity & 0.35 & 0.09 & 0.42 & 0.11 & 0.35 & 0.06 & 0.03 & 0.02 & 0.48 & 0.06 & 0.47 & 0.07 & 0.52 & 0.06 & 0.22 & 0.06 & 0.24 & 0.865 \\
\hline Richness & 0.72 & 0.12 & 0.98 & 0.23 & 1.02 & 0.30 & 0.23 & 0.10 & 1.09 & 0.14 & 1.11 & 0.19 & 1.32 & 0.16 & 0.54 & 0.09 & 0.37 & 0.774 \\
\hline
\end{tabular}

\footnotetext{
${ }^{\mathrm{a}}$ Results of year ${ }^{\mathrm{x}}$ month interactions $(\mathrm{df}=3,32)$.
} 
Appendix IIIh. Breeding grassland bird density (number/ha), diversity, and richness by habitat types and month on the Canaan Valley

National Wildlife Refuge, Tucker County, West Virginia, May-August,1999-2000.

\begin{tabular}{|c|c|c|c|c|c|c|c|c|c|c|c|c|c|c|c|c|c|c|}
\hline \multirow[b]{4}{*}{ Species } & \multicolumn{8}{|c|}{ Pasture } & \multicolumn{8}{|c|}{ Hayfield } & \multicolumn{2}{|c|}{$\underline{\text { 2-way }} \underline{\text { interaction }}^{\mathrm{a}}$} \\
\hline & \multirow{2}{*}{\multicolumn{2}{|c|}{ May }} & & & & & & & & & & & & & & & & \\
\hline & & & \multicolumn{2}{|c|}{ June } & \multicolumn{2}{|c|}{ July } & \multicolumn{2}{|c|}{ August } & \multicolumn{2}{|c|}{ May } & \multicolumn{2}{|c|}{ June } & \multicolumn{2}{|c|}{ July } & \multicolumn{2}{|c|}{ August } & \multirow{2}{*}{$\begin{array}{c}F- \\
\text { value }\end{array}$} & \multirow{2}{*}{$\begin{array}{c}P \text { - } \\
\text { value }\end{array}$} \\
\hline & $\bar{x}$ & SE & $\bar{x}$ & SE & $\bar{x}$ & SE & $\bar{x}$ & $\mathrm{SE}$ & $\bar{x}$ & SE & $\bar{x}$ & SE & $\overline{\mathrm{x}}$ & SE & $\bar{x}$ & SE & & \\
\hline Overall & 1.47 & 0.57 & 3.86 & 1.36 & 11.54 & 7.55 & 7.65 & 7.15 & 1.53 & 0.42 & 3.24 & 1.07 & 5.61 & 2.28 & 4.09 & 3.21 & 0.05 & 0.984 \\
\hline Bobolink & 0.43 & 0.27 & 0.85 & 0.57 & 3.13 & 2.07 & 3.59 & 3.59 & 0.15 & 0.10 & 0.16 & 0.10 & 0.76 & 0.45 & 1.84 & 1.64 & 0.29 & 0.835 \\
\hline $\begin{array}{l}\text { Eastern } \\
\text { meadowlark }\end{array}$ & 0.09 & 0.06 & 0.13 & 0.07 & 0.04 & 0.02 & 0.09 & 0.09 & 0.27 & 0.11 & 0.24 & 0.08 & 0.32 & 0.10 & 0.21 & 0.10 & 0.88 & 0.464 \\
\hline $\begin{array}{l}\text { Savannah } \\
\text { sparrow }\end{array}$ & 0.17 & 0.13 & 0.55 & 0.17 & 0.22 & 0.10 & 0.14 & 0.08 & 0.40 & 0.10 & 0.39 & 0.12 & 0.49 & 0.11 & 0.25 & 0.15 & 1.45 & 0.247 \\
\hline Diversity & 0.43 & 0.06 & 0.41 & 0.07 & 0.46 & 0.05 & 0.16 & 0.07 & 0.44 & 0.09 & 0.50 & 0.09 & 0.45 & 0.09 & 0.14 & 0.06 & 0.43 & 0.731 \\
\hline Richness & 0.81 & 0.10 & 0.77 & 0.16 & 0.97 & 0.14 & 0.36 & 0.09 & 1.12 & 0.19 & 1.40 & 0.20 & 1.49 & 0.25 & 0.50 & 0.12 & 1.01 & 0.401 \\
\hline
\end{tabular}

${ }^{a}$ Results of habitat types ${ }^{x}$ month interactions $(\mathrm{df}=3,32)$. 
Appendix IVa: Means ( $\overline{\mathrm{x}}$ ), standard errors (SE), and test statistics of vegetative variables measured on hayfields between mowed and unmowed portions on the Canaan Valley National Wildlife Refuge, Tucker County, West Virginia, June-August, 2000.

\begin{tabular}{|c|c|c|c|c|c|c|c|c|c|c|c|c|c|c|c|c|}
\hline \multirow[b]{3}{*}{ Variables } & & \multicolumn{6}{|c|}{ Mowed } & \multicolumn{6}{|c|}{ Unmowed } & \multicolumn{3}{|c|}{$\underline{3-w a y ~ i n t e r a c t i o n ~}^{a}$} \\
\hline & & \multicolumn{2}{|c|}{ June } & \multicolumn{2}{|c|}{ July } & \multicolumn{2}{|c|}{ August } & \multicolumn{2}{|c|}{ June } & \multicolumn{2}{|c|}{ July } & \multicolumn{2}{|c|}{ August } & \multirow{2}{*}{$\begin{array}{c}\text { Wilks' } \\
\lambda\end{array}$} & \multirow{2}{*}{$\begin{array}{c}F- \\
\text { value }\end{array}$} & \multirow[t]{2}{*}{$P$-value } \\
\hline & & $\overline{\mathrm{x}}$ & SE & $\bar{x}$ & SE & $\overline{\mathrm{x}}$ & SE & $\overline{\mathrm{x}}$ & SE & $\bar{x}$ & SE & $\overline{\mathrm{x}}$ & SE & & & \\
\hline \multirow[t]{4}{*}{$\begin{array}{l}\text { Ground } \\
\text { Cover }(\%)\end{array}$} & & & & & & & & & & & & & & 0.914 & ----- & 0.937 \\
\hline & Canopy & 62.36 & 3.10 & 75.26 & 3.28 & 90.24 & 2.04 & 60.33 & 1.50 & 78.35 & 1.80 & 85.57 & 3.94 & & & \\
\hline & Litter & 31.23 & 4.82 & 19.64 & 6.86 & 7.20 & 2.14 & 34.85 & 3.64 & 17.85 & 4.25 & 11.50 & 3.17 & & & \\
\hline & $\begin{array}{l}\text { Bare } \\
\text { Ground }\end{array}$ & 6.47 & 5.78 & 5.10 & 3.99 & 2.55 & 2.03 & 4.87 & 4.06 & 3.79 & 2.82 & 3.00 & 2.75 & & & \\
\hline \multirow{3}{*}{$\begin{array}{l}\text { Growth } \\
\text { State }(\%)\end{array}$} & & & & & & & & & & & & & & 0.910 & ----- & 0.747 \\
\hline & Live & 61.91 & 2.83 & 73.92 & 2.46 & 83.62 & 5.17 & 57.91 & 1.11 & 75.55 & 1.39 & 78.90 & 4.70 & & & \\
\hline & Dead & 0.52 & 0.29 & 1.34 & 1.17 & 3.29 & 0.65 & 2.37 & 0.85 & 2.81 & 0.52 & 6.67 & 1.12 & & & \\
\hline \multirow{4}{*}{$\begin{array}{l}\text { Vegetative } \\
\text { Cover }(\%)\end{array}$} & & & & & & & & & & & & & & 0.955 & ----- & 0.989 \\
\hline & Forbs & 30.01 & 4.27 & 37.90 & 2.07 & 39.55 & 5.89 & 24.62 & 4.23 & 36.69 & 4.65 & 36.45 & 3.56 & & & \\
\hline & Grasses & 32.03 & 1.14 & 36.08 & 4.55 & 45.49 & 1.91 & 33.66 & 3.49 & 38.43 & 4.32 & 45.63 & 4.86 & & & \\
\hline & Wood & 0.32 & 0.24 & 1.11 & 1.11 & 1.81 & 1.81 & 2.00 & 2.00 & 3.23 & 3.19 & 3.49 & 3.49 & & & \\
\hline $\begin{array}{l}\text { Vertical } \\
\text { Density } \\
(\mathrm{cm})\end{array}$ & & 8.58 & 0.43 & 16.29 & 2.84 & 20.09 & 3.04 & 11.76 & 1.52 & 23.81 & 7.72 & 28.31 & 5.52 & ----- & 0.02 & 0.978 \\
\hline $\begin{array}{l}\text { Maximum } \\
\text { Height }(\mathrm{cm})\end{array}$ & & 24.05 & 1.19 & 52.88 & 2.24 & 59.23 & 2.66 & 29.64 & 2.53 & 55.05 & 4.31 & 63.85 & 5.57 & ----- & 0.09 & 0.919 \\
\hline $\begin{array}{l}\text { Litter Depth } \\
(\mathrm{cm})\end{array}$ & & 2.22 & 0.13 & 2.06 & 0.50 & 1.50 & 0.23 & 3.64 & 0.67 & 3.23 & 0.22 & 2.52 & 0.51 & ---- & 0.11 & 0.89 \\
\hline
\end{tabular}

${ }^{\mathrm{a}}$ Results of treatments ${ }^{\mathrm{x}}$ habitat types ${ }^{\mathrm{x}}$ months $(\mathrm{df}=3,21)$. 
Appendix IVb. Means ( $\overline{\mathrm{x}}$ ), standard errors (SE), and test statistics of vegetative variables measured on pastures between mowed and unmowed portions on the Canaan Valley National Wildlife Refuge, Tucker County, West Virginia, June-August, 2000.

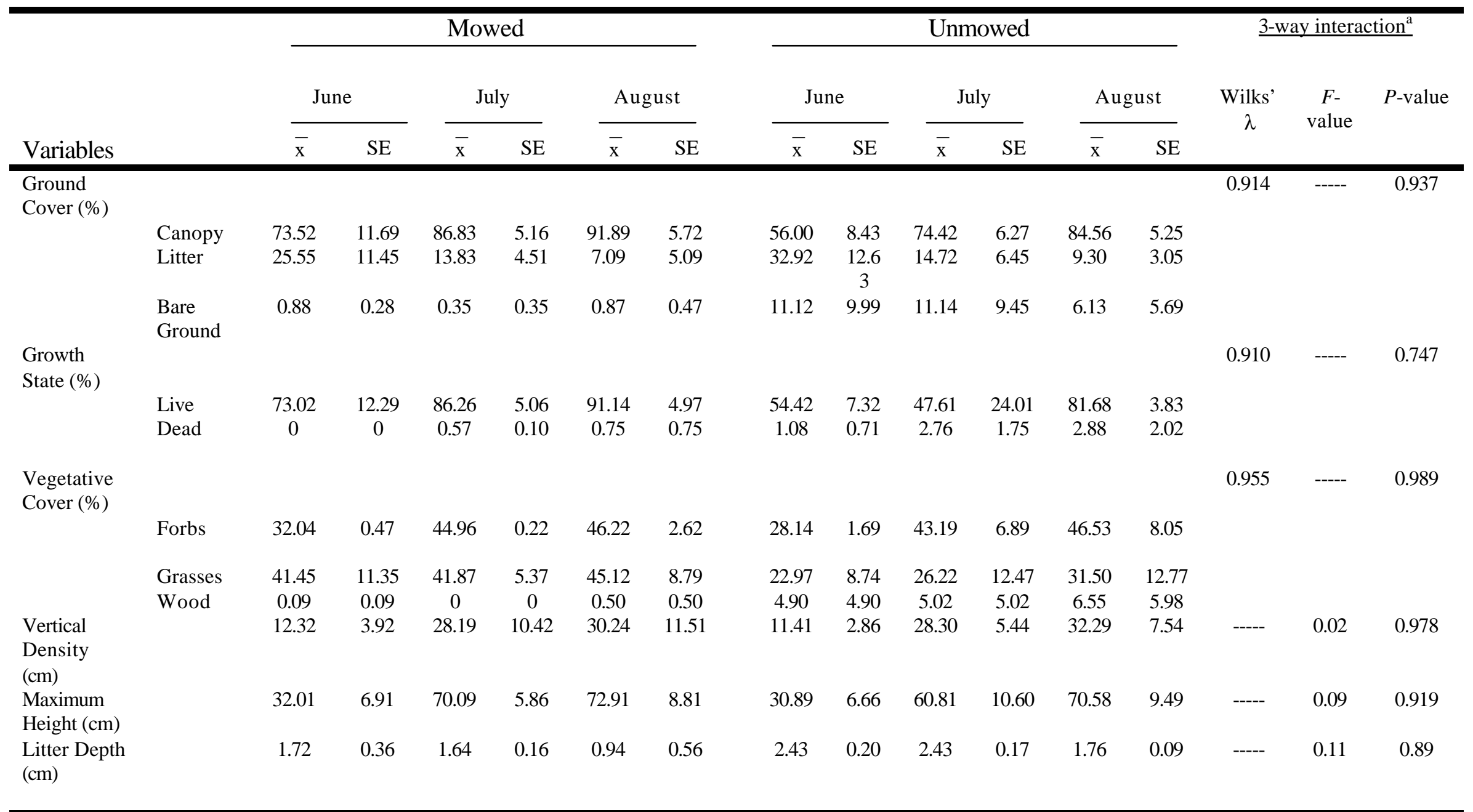

${ }^{\mathrm{a}}$ Results of treatments ${ }^{\mathrm{x}}$ habitat types ${ }^{\mathrm{x}}$ months $(\mathrm{df}=3,21)$. 
Appendix IVc: Means ( $\overline{\mathrm{x}}$ ), standard errors (SE), and test statistics of vegetative variables measured between hayfields and pastures

for on the Canaan Valley National Wildlife Refuge, Tucker County, West Virginia, June-August, 2000.

\begin{tabular}{|c|c|c|c|c|c|c|c|c|c|c|c|c|c|c|c|c|}
\hline \multirow[b]{3}{*}{ Variables } & & \multicolumn{6}{|c|}{ Hayfields } & \multicolumn{6}{|c|}{ Pasture } & \multicolumn{3}{|c|}{ 2-way interaction ${ }^{\mathrm{a}}$} \\
\hline & & \multicolumn{2}{|c|}{ June } & \multicolumn{2}{|c|}{ July } & \multicolumn{2}{|c|}{ August } & \multicolumn{2}{|c|}{ June } & \multicolumn{2}{|c|}{ July } & \multicolumn{2}{|c|}{ August } & \multirow{2}{*}{$\begin{array}{l}\text { Wilks' } \\
\lambda\end{array}$} & \multirow{2}{*}{$\begin{array}{l}F- \\
\text { value }\end{array}$} & \multirow{2}{*}{$\begin{array}{l}P \text { - } \\
\text { value }\end{array}$} \\
\hline & & $\bar{x}$ & $\mathrm{SE}$ & $\bar{x}$ & $\mathrm{SE}$ & $\bar{x}$ & $\mathrm{SE}$ & $\bar{x}$ & $\mathrm{SE}$ & $\bar{x}$ & $\mathrm{SE}$ & $\bar{x}$ & $\mathrm{SE}$ & & & \\
\hline \multirow{4}{*}{$\begin{array}{l}\text { Ground } \\
\text { Cover }\end{array}$} & & & & & & & & & & & & & & 0.9773 & ----- & 0.998 \\
\hline & Canopy & 61.35 & 1.61 & 76.81 & 1.81 & 87.91 & 2.24 & 63.01 & 7.31 & 79.38 & 4.87 & 87.49 & 3.84 & & & \\
\hline & Litter & 33.04 & 2.82 & 18.75 & 3.63 & 9.35 & 1.96 & 29.97 & 8.01 & 14.36 & 3.82 & 8.42 & 2.38 & & & \\
\hline & $\begin{array}{l}\text { Bare } \\
\text { Ground }\end{array}$ & 5.67 & 3.18 & 4.45 & 2.20 & 2.78 & 1.53 & 7.03 & 6.02 & 6.83 & 5.81 & 4.03 & 3.38 & & & \\
\hline \multirow{3}{*}{$\begin{array}{l}\text { Growth } \\
\text { State }\end{array}$} & & & & & & & & & & & & & & 0.955 & ----- & 0.920 \\
\hline & Live & 59.91 & 1.63 & 74.73 & 1.31 & 81.26 & 3.30 & 61.86 & 7.20 & 63.07 & 16.2 & 85.46 & 3.50 & & & \\
\hline & Dead & 1.44 & 0.58 & 2.07 & 0.66 & 4.98 & 0.95 & 0.65 & 0.47 & 1.88 & $\begin{array}{c}8 \\
1.10\end{array}$ & 2.03 & 1.25 & & & \\
\hline \multirow{4}{*}{$\begin{array}{l}\text { Vegetative } \\
\text { Cover }\end{array}$} & & & & & & & & & & & & & & 0.962 & ----- & 0.993 \\
\hline & Forbs & 27.32 & 2.95 & 37.30 & 2.29 & 38.00 & 3.16 & 29.70 & 1.34 & 43.89 & 3.80 & 46.40 & 4.49 & & & \\
\hline & Grasses & 32.84 & 1.68 & 37.26 & 2.86 & 45.56 & 2.33 & 30.36 & 7.50 & 32.48 & 8.02 & 36.95 & 8.23 & & & \\
\hline & Wood & 1.16 & 0.98 & 2.17 & 1.58 & 2.65 & 1.80 & 2.97 & 2.93 & 3.01 & 3.01 & 4.13 & 3.60 & & & \\
\hline $\begin{array}{l}\text { Vertical } \\
\text { Density } \\
(\mathrm{cm})\end{array}$ & & 10.17 & 1.00 & 20.05 & 4.05 & 24.20 & 3.37 & 11.77 & 2.01 & 28.25 & 4.44 & 31.47 & 5.53 & ----- & 0.33 & 0.725 \\
\hline $\begin{array}{l}\text { Maximum } \\
\text { Height (cm) }\end{array}$ & & 26.85 & 1.77 & 53.96 & 2.23 & 61.54 & 2.95 & 31.34 & 4.26 & 64.52 & 6.50 & 71.51 & 5.93 & ----- & 0.04 & 0.963 \\
\hline $\begin{array}{l}\text { Litter Depth } \\
(\mathrm{cm})\end{array}$ & & 2.93 & 0.44 & 2.64 & 0.36 & 2.01 & 0.34 & 2.14 & 0.23 & 2.12 & 0.22 & 1.43 & 0.27 & ----- & 0.16 & 0.857 \\
\hline
\end{tabular}


Appendix IVd: Means ( $\overline{\mathrm{x}}$ ), standard errors (SE), test statistics of vegetative variables measured between mowed and unmowed treatments on the Canaan Valley National Wildlife Refuge, Tucker County, West Virginia, June-August, 2000.

\begin{tabular}{|c|c|c|c|c|c|c|c|c|c|c|c|c|c|c|c|c|}
\hline \multirow[b]{3}{*}{ Variables } & & \multicolumn{6}{|c|}{ Mowed } & \multicolumn{6}{|c|}{ Unmowed } & \multicolumn{3}{|c|}{ 2-way interaction ${ }^{\mathrm{a}}$} \\
\hline & & \multicolumn{2}{|c|}{ June } & \multicolumn{2}{|c|}{ July } & \multicolumn{2}{|c|}{ August } & \multicolumn{2}{|c|}{ June } & \multicolumn{2}{|c|}{ July } & \multicolumn{2}{|c|}{ August } & \multirow{2}{*}{$\begin{array}{c}\text { Wilks' } \\
\quad \lambda\end{array}$} & \multirow{2}{*}{$F$-value } & \multirow{2}{*}{$\begin{array}{c}P \text { - } \\
\text { value }\end{array}$} \\
\hline & & $\overline{\mathrm{x}}$ & SE & $\overline{\mathrm{x}}$ & SE & $\overline{\mathrm{x}}$ & SE & $\overline{\mathrm{x}}$ & SE & $\overline{\mathrm{x}}$ & SE & $\overline{\mathrm{x}}$ & SE & & & \\
\hline \multirow{4}{*}{$\begin{array}{l}\text { Ground } \\
\text { Cover }\end{array}$} & & & & & & & & & & & & & & 0.854 & ----- & 0.790 \\
\hline & Canopy & 66.82 & 4.90 & 79.88 & 3.73 & 90.90 & 2.16 & 58.17 & 3.95 & 76.39 & 3.05 & 85.07 & 2.94 & & & \\
\hline & Litter & 28.96 & 4.69 & 17.31 & 4.26 & 7.16 & 1.99 & 33.88 & 5.89 & 16.29 & 3.53 & 10.40 & 2.03 & & & \\
\hline & $\begin{array}{l}\text { Bare } \\
\text { Ground }\end{array}$ & 4.23 & 3.45 & 3.20 & 2.48 & 1.88 & 1.20 & 8.00 & 5.02 & 7.47 & 4.71 & 4.57 & 2.91 & & & \\
\hline \multirow{3}{*}{$\begin{array}{l}\text { Growth } \\
\text { State }\end{array}$} & & & & & & & & & & & & & & 0.978 & ----- & 0.974 \\
\hline & Live & 66.35 & 4.99 & 78.86 & 3.68 & 86.63 & 3.73 & 56.16 & 3.40 & 61.58 & $\begin{array}{c}12.4 \\
4\end{array}$ & 80.29 & 2.78 & & & \\
\hline & Dead & 0.31 & 0.20 & 1.03 & 0.67 & 2.27 & 0.75 & 1.72 & 0.57 & 2.79 & 0.82 & 4.78 & 1.33 & & & \\
\hline \multirow{4}{*}{$\begin{array}{l}\text { Vegetative } \\
\text { Cover }\end{array}$} & & & & & & & & & & & & & & 0.934 & ----- & 0.968 \\
\hline & Forbs & 30.82 & 2.39 & 40.72 & 2.07 & 42.22 & 3.71 & 26.38 & 2.19 & 39.94 & 3.99 & 41.49 & 4.54 & & & \\
\hline & Grasses & 35.80 & 4.31 & 38.40 & 3.33 & 45.34 & 2.97 & 28.31 & 4.84 & 32.32 & 6.51 & 38.56 & 6.88 & & & \\
\hline & Wood & 0.23 & 0.15 & 0.67 & 0.67 & 1.28 & 1.05 & 3.45 & 2.45 & 4.12 & 2.69 & 5.02 & 3.17 & & & \\
\hline $\begin{array}{l}\text { Vertical } \\
\text { Density } \\
(\mathrm{cm})\end{array}$ & & 10.08 & 1.56 & 21.05 & 4.66 & 24.15 & 4.71 & 11.59 & 1.45 & 26.06 & 4.34 & 30.30 & 4.27 & ----- & 0.07 & 0.936 \\
\hline $\begin{array}{l}\text { Maximum } \\
\text { Height }(\mathrm{cm})\end{array}$ & & 27.23 & 3.00 & 59.76 & 4.76 & 64.70 & 4.59 & 30.27 & 3.20 & 57.93 & 5.28 & 67.22 & 5.15 & ----- & 0.33 & 0.724 \\
\hline $\begin{array}{l}\text { Litter Depth } \\
(\mathrm{cm})\end{array}$ & & 2.02 & 0.18 & 1.89 & 0.30 & 1.27 & 0.26 & 3.04 & 0.42 & 2.83 & 0.22 & 2.14 & 0.29 & ----- & 0.04 & 0.962 \\
\hline
\end{tabular}

${ }^{\mathrm{a}}$ Results of treatments ${ }^{\mathrm{x}}$ months $(\mathrm{df}=3,21)$. 
Appendix IVe. Mean ( $\overline{\mathrm{x}}$ ), standard error (SE), and test statistics of all vegetative characteristics measured on hayfields and pastures during 1999 on the Canaan Valley National Wildlife Refuge, Tucker County, West Virginia, June-August, 1999-2000.

\begin{tabular}{|c|c|c|c|c|c|c|c|c|c|c|c|c|c|c|c|c|}
\hline \multirow[b]{3}{*}{ Variables } & & \multicolumn{6}{|c|}{ Hayfields } & \multicolumn{6}{|c|}{ Pastures } & \multicolumn{3}{|c|}{$\underline{3 \text {-way interaction }}{ }^{\text {a }}$} \\
\hline & & \multicolumn{2}{|c|}{ June } & \multicolumn{2}{|c|}{ July } & \multicolumn{2}{|c|}{ August } & \multicolumn{2}{|c|}{ June } & \multicolumn{2}{|c|}{ July } & \multicolumn{2}{|c|}{ August } & \multirow{2}{*}{$\begin{array}{l}\text { Wilks' } \\
\quad \lambda\end{array}$} & \multirow{2}{*}{$\begin{array}{c}F- \\
\text { value }\end{array}$} & \multirow[t]{2}{*}{$P$-value } \\
\hline & & $\bar{x}$ & SE & $\bar{x}$ & SE & $\bar{x}$ & SE & $\bar{x}$ & SE & $\bar{x}$ & SE & $\bar{x}$ & $\mathrm{SE}$ & & & \\
\hline \multirow{4}{*}{$\begin{array}{l}\text { Ground } \\
\text { Cover }(\%)\end{array}$} & & & & & & & & & & & & & & 0.913 & ---- & 0.910 \\
\hline & Canopy & 60.62 & 3.44 & 58.44 & 1.32 & 47.16 & 23.52 & 54.82 & 6.52 & 72.87 & 4.74 & 74.47 & 2.41 & & & \\
\hline & Litter & 34.84 & 6.74 & 37.65 & 4.56 & 37.34 & 3.40 & 36.25 & 3.99 & 23.95 & 5.75 & 23.50 & 4.26 & & & \\
\hline & $\begin{array}{l}\text { Bare } \\
\text { Ground }\end{array}$ & 5.17 & 4.06 & 0.39 & 0.33 & 0 & 0 & 9.13 & 7.20 & 3.08 & 2.48 & 1.73 & 1.73 & & & \\
\hline \multirow{3}{*}{$\begin{array}{l}\text { Growth } \\
\text { State }(\%)\end{array}$} & & & & & & & & & & & & & & 0.841 & ----- & 0.396 \\
\hline & Live & 60.04 & 3.41 & 58.37 & 1.31 & 65.84 & 5.30 & 54.50 & 6.20 & 72.87 & 4.73 & 74.31 & 2.26 & & & \\
\hline & Dead & 0.55 & 0.26 & 0.05 & 0.03 & 0.36 & 0.07 & 0.49 & 0.36 & 0.01 & 0.01 & 0.24 & 0.18 & & & \\
\hline \multirow{4}{*}{$\begin{array}{l}\text { Vegetative } \\
\text { Cover }(\%)\end{array}$} & & & & & & & & & & & & & & 0.905 & ----- & 0.891 \\
\hline & Forbs & 25.74 & 5.68 & 37.03 & 4.20 & 33.41 & 5.95 & 31.67 & 4.56 & 41.36 & 5.40 & 38.35 & 7.18 & & & \\
\hline & Grasses & 31.47 & 2.53 & 16.10 & 8.07 & 32.34 & 0.92 & 20.99 & 5.64 & 21.35 & 11.59 & 29.68 & 6.15 & & & \\
\hline & Wood & 2.65 & 2.65 & 1.74 & 1.68 & 1.62 & 1.62 & 2.04 & 2.04 & 6.81 & 6.81 & 6.44 & 6.44 & & & \\
\hline $\begin{array}{l}\text { Vertical } \\
\text { Density } \\
(\mathrm{cm})\end{array}$ & & 8.84 & 1.23 & 12.30 & 2.87 & 15.73 & 5.90 & 8.94 & 1.29 & 16.49 & 3.11 & 13.55 & 0.63 & ----- & 0.08 & 0.919 \\
\hline $\begin{array}{l}\text { Maximum } \\
\text { Height }(\mathrm{cm})\end{array}$ & & 23.65 & 2.65 & 32.17 & 3.06 & 35.98 & 3.77 & 27.12 & 1.49 & 44.56 & 3.08 & 51.69 & 6.02 & ----- & 0.09 & 0.9106 \\
\hline $\begin{array}{l}\text { Litter Depth } \\
(\mathrm{cm})\end{array}$ & & 3.37 & 0.41 & 3.11 & 0.44 & 3.33 & 0.59 & 2.31 & 0.08 & 2.11 & 0.37 & 2.53 & 0.54 & ----- & 0.05 & 0.953 \\
\hline
\end{tabular}

${ }^{\mathrm{a}}$ Results of years ${ }^{\mathrm{x}}$ habitat types ${ }^{\mathrm{x}}$ months interactions $(\mathrm{df}=3,24)$. 
Appendix IVf. Mean ( $\overline{\mathrm{x}}$ ), standard error (SE), and test statistics of all vegetative characteristics measured on hayfields and pastures

during 1999 on the Canaan Valley National Wildlife Refuge, Tucker County, West Virginia, June-August, 1999-2000.

\begin{tabular}{|c|c|c|c|c|c|c|c|c|c|c|c|c|c|c|c|c|}
\hline \multirow[b]{3}{*}{ Variables } & & \multicolumn{6}{|c|}{ Hayfields } & \multicolumn{6}{|c|}{ Pastures } & \multicolumn{3}{|c|}{$\underline{3 \text {-way interaction }}{ }^{\mathrm{a}}$} \\
\hline & & \multicolumn{2}{|c|}{ June } & \multicolumn{2}{|c|}{ July } & \multicolumn{2}{|c|}{ August } & \multicolumn{2}{|c|}{ June } & \multicolumn{2}{|c|}{ July } & \multicolumn{2}{|c|}{ August } & \multirow{2}{*}{$\begin{array}{c}\text { Wilks' } \\
\lambda\end{array}$} & \multirow{2}{*}{$\begin{array}{c}F- \\
\text { value }\end{array}$} & \multirow[t]{2}{*}{$P$-value } \\
\hline & & $\bar{x}$ & SE & $\bar{x}$ & SE & $\bar{x}$ & SE & $\bar{x}$ & SE & $\bar{x}$ & SE & $\bar{x}$ & SE & & & \\
\hline \multirow[t]{4}{*}{$\begin{array}{l}\text { Ground } \\
\text { Cover }(\%)\end{array}$} & & & & & & & & & & & & & & 0.913 & ----- & 0.910 \\
\hline & Canopy & 60.33 & 1.50 & 78.35 & 1.80 & 85.57 & 3.94 & 56.00 & 8.43 & 74.42 & 6.27 & 84.56 & 5.25 & & & \\
\hline & Litter & 34.85 & 3.64 & 17.85 & 4.25 & 11.50 & 3.17 & 32.92 & 12.63 & 14.72 & 6.45 & 9.30 & 3.05 & & & \\
\hline & $\begin{array}{l}\text { Bare } \\
\text { Ground }\end{array}$ & 4.87 & 4.06 & 3.79 & 2.82 & 3.00 & 2.75 & 11.12 & 9.99 & 11.14 & 9.45 & 6.13 & 5.69 & & & \\
\hline \multirow{3}{*}{$\begin{array}{l}\text { Growth } \\
\text { State }(\%)\end{array}$} & & & & & & & & & & & & & & 0.841 & ----- & 0.396 \\
\hline & Live & 57.91 & 1.11 & 75.55 & 1.39 & 78.90 & 4.70 & 54.42 & 7.32 & 47.61 & 24.01 & 81.68 & 3.83 & & & \\
\hline & Dead & 2.37 & 0.85 & 2.81 & 0.52 & 6.67 & 1.12 & 1.08 & 0.71 & 2.76 & 1.75 & 2.88 & 2.02 & & & \\
\hline \multirow{4}{*}{$\begin{array}{l}\text { Vegetative } \\
\text { Cover }(\%)\end{array}$} & & & & & & & & & & & & & & 0.905 & ----- & 0.891 \\
\hline & Forbs & 24.62 & 4.23 & 36.69 & 4.65 & 36.45 & 3.56 & 28.14 & 1.69 & 43.19 & 6.89 & 46.53 & 8.05 & & & \\
\hline & Grasses & 33.66 & 3.49 & 38.43 & 4.32 & 45.63 & 4.86 & 22.97 & 8.74 & 26.22 & 12.47 & 31.50 & 12.77 & & & \\
\hline & Wood & 2.00 & 2.00 & 3.23 & 3.19 & 3.49 & 3.49 & 4.90 & 4.90 & 5.02 & 5.02 & 6.55 & 5.98 & & & \\
\hline Vertical & & 11.76 & 1.52 & 23.81 & 7.72 & 28.31 & 5.52 & 11.41 & 2.86 & 28.30 & 5.44 & 32.29 & 7.54 & ----- & 0.08 & 0.919 \\
\hline $\begin{array}{l}\text { Density } \\
(\mathrm{cm})\end{array}$ & & & & & & & & & & & & & & & & \\
\hline Maximum & & 29.64 & 2.53 & 55.05 & 4.31 & 63.85 & 5.57 & 30.89 & 6.66 & 60.81 & 10.60 & 70.58 & 9.49 & ----- & 0.09 & 0.9106 \\
\hline $\begin{array}{l}\text { Height }(\mathrm{cm}) \\
\text { Litter Depth } \\
(\mathrm{cm})\end{array}$ & & 3.64 & 67.36 & 3.23 & 0.22 & 2.52 & 0.51 & 2.43 & 0.20 & 2.43 & 0.17 & 1.76 & 0.09 & ----- & 0.05 & 0.953 \\
\hline
\end{tabular}

${ }^{a}$ Results of years ${ }^{\mathrm{x}}$ habitat types ${ }^{\mathrm{x}}$ months interactions $(\mathrm{df}=3,24)$. 
Appendix IVg: Mean ( $\bar{x}$ ), standard error (SE), and test statistics of all vegetative characteristics measured during 1999 and 2000 for each month on the Canaan Valley National Wildlife Refuge, Tucker County, West Virginia.

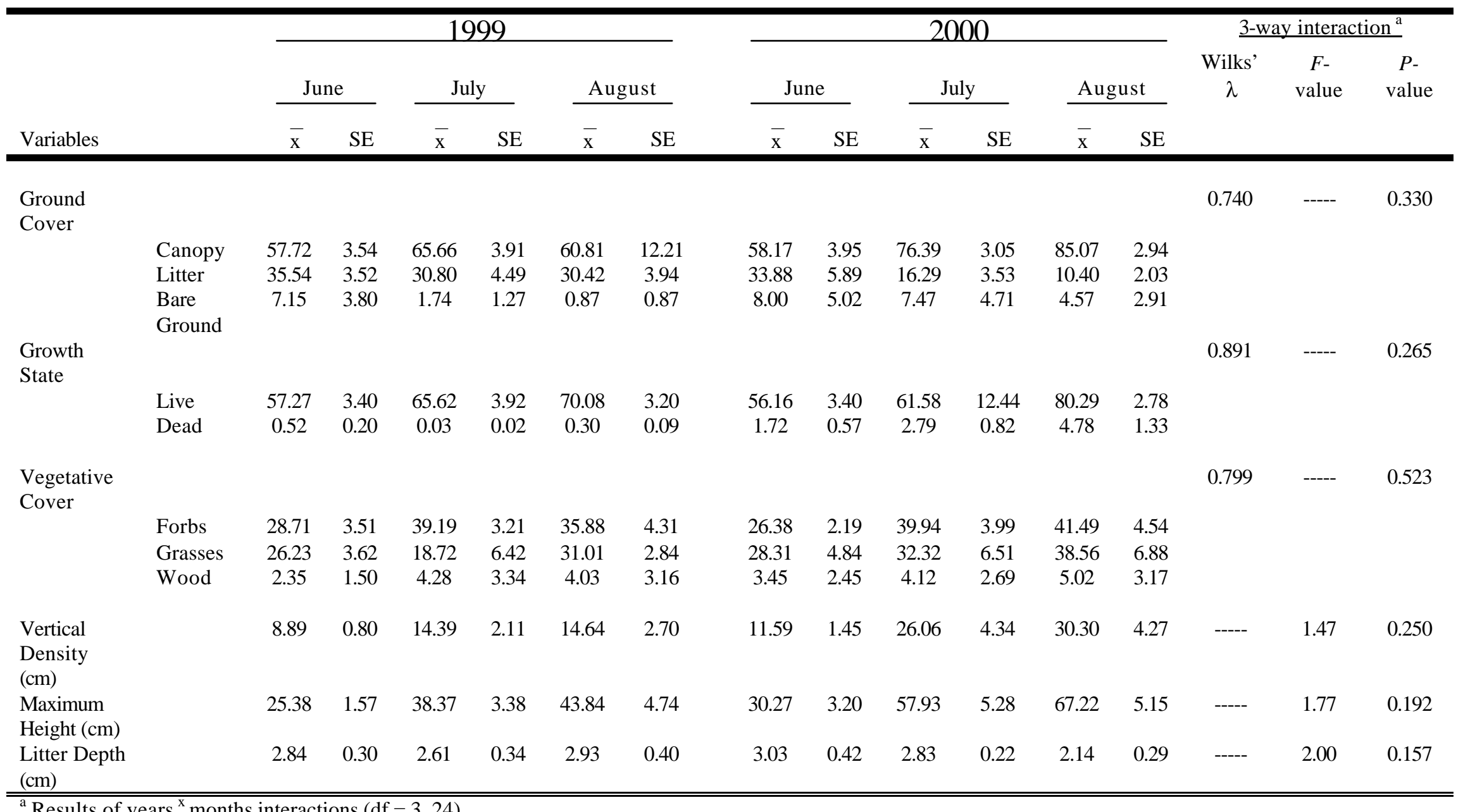


Appendix IVh: Mean ( $\overline{\mathrm{x}}$ ), standard error (SE), and test statistics of all vegetative characteristics measured during between hayfields and pastures for each month on the Canaan Valley National Wildlife Refuge, Tucker County, West Virginia 1999-2000.

\begin{tabular}{|c|c|c|c|c|c|c|c|c|c|c|c|c|c|c|c|c|}
\hline \multirow[b]{3}{*}{ Variables } & & \multicolumn{6}{|c|}{ Hayfields } & \multicolumn{6}{|c|}{ Pastures } & \multirow[t]{3}{*}{ Wilks' $\lambda$} & \multirow[t]{3}{*}{ F-value } & \multirow[t]{3}{*}{ P-value } \\
\hline & & \multicolumn{2}{|c|}{ June } & \multicolumn{2}{|c|}{ July } & \multicolumn{2}{|c|}{ August } & \multicolumn{2}{|c|}{ June } & \multicolumn{2}{|c|}{ July } & \multicolumn{2}{|c|}{ August } & & & \\
\hline & & $\bar{x}$ & SE & $\bar{x}$ & $\mathrm{SE}$ & $\bar{x}$ & SE & $\bar{x}$ & SE & $\overline{\mathrm{x}}$ & SE & $\overline{\mathrm{X}}$ & SE & & & \\
\hline \multirow{4}{*}{$\begin{array}{l}\text { Ground } \\
\text { Cover (\%) }\end{array}$} & & & & & & & & & & & & & & 0.888 & ----- & 0.841 \\
\hline & Canopy & 60.48 & 1.68 & 68.40 & 4.56 & 66.36 & 13.69 & 55.41 & 4.77 & 73.65 & 3.53 & 79.52 & 3.43 & & & \\
\hline & Litter & 34.84 & 3.43 & 27.75 & 5.23 & 24.42 & 6.14 & 34.59 & 5.97 & 19.33 & 4.38 & 16.40 & 3.95 & & & \\
\hline & $\begin{array}{l}\text { Bare } \\
\text { Ground }\end{array}$ & 5.02 & 2.57 & 2.09 & 1.48 & 1.50 & 1.40 & 10.13 & 5.53 & 7.11 & 4.73 & 3.93 & 2.84 & & & \\
\hline \multirow{3}{*}{$\begin{array}{l}\text { Growth } \\
\text { State }(\%)\end{array}$} & & & & & & & & & & & & & & 0.943 & ----- & 0.849 \\
\hline & Live & 58.97 & 1.67 & 66.96 & 3.94 & 72.37 & 4.31 & 54.46 & 4.29 & 60.24 & $\begin{array}{c}12.3 \\
2\end{array}$ & 78.00 & 2.58 & & & \\
\hline & Dead & 1.46 & 0.57 & 1.43 & 0.66 & 3.51 & 1.50 & 0.79 & 0.38 & 1.39 & 1.00 & 1.56 & 1.08 & & & \\
\hline \multirow{4}{*}{$\begin{array}{l}\text { Vegetative } \\
\text { Cover }(\%)\end{array}$} & & & & & & & & & & & & & & 0.888 & ---- & 0.842 \\
\hline & Forbs & 25.18 & 3.18 & 36.86 & 2.80 & 34.93 & 3.17 & 29.91 & 2.31 & 42.27 & 3.94 & 42.44 & 5.16 & & & \\
\hline & Grasses & 32.57 & 1.99 & 27.26 & 6.46 & 38.98 & 3.70 & 21.98 & 4.67 & 23.78 & 7.69 & 30.59 & 6.35 & & & \\
\hline & Wood & 2.33 & 1.49 & 2.48 & 1.65 & 2.55 & 1.77 & 3.47 & 2.46 & 5.92 & 3.81 & 6.50 & 3.93 & & & \\
\hline $\begin{array}{l}\text { Vertical } \\
\text { Density } \\
(\mathrm{cm})\end{array}$ & & 10.30 & 1.09 & 18.05 & 4.50 & 22.02 & 4.58 & 10.18 & 1.51 & 22.40 & 3.85 & 22.92 & 5.39 & ----- & 0.52 & 0.604 \\
\hline $\begin{array}{l}\text { Maximum } \\
\text { Height }(\mathrm{cm})\end{array}$ & & 26.64 & 2.12 & 43.61 & 5.63 & 49.92 & 6.92 & 29.00 & 3.17 & 52.69 & 6.13 & 61.13 & 6.57 & ----- & 0.47 & 0.629 \\
\hline $\begin{array}{l}\text { Litter Depth } \\
(\mathrm{cm})\end{array}$ & & 3.51 & 0.36 & 3.17 & 0.22 & 2.93 & 0.39 & 2.37 & 0.10 & 2.27 & 0.19 & 2.15 & 0.30 & ----- & 0.20 & 0.819 \\
\hline
\end{tabular}

${ }^{\mathrm{a}}$ Results of habitat types ${ }^{\mathrm{x}}$ months interactions $(\mathrm{df}=3,24)$. 
Appendix V. Vegetation (\%) found at nest sites on the Canaan Valley National Wildlife Refuge, Tucker County, West Virginia, 1999-

2000.

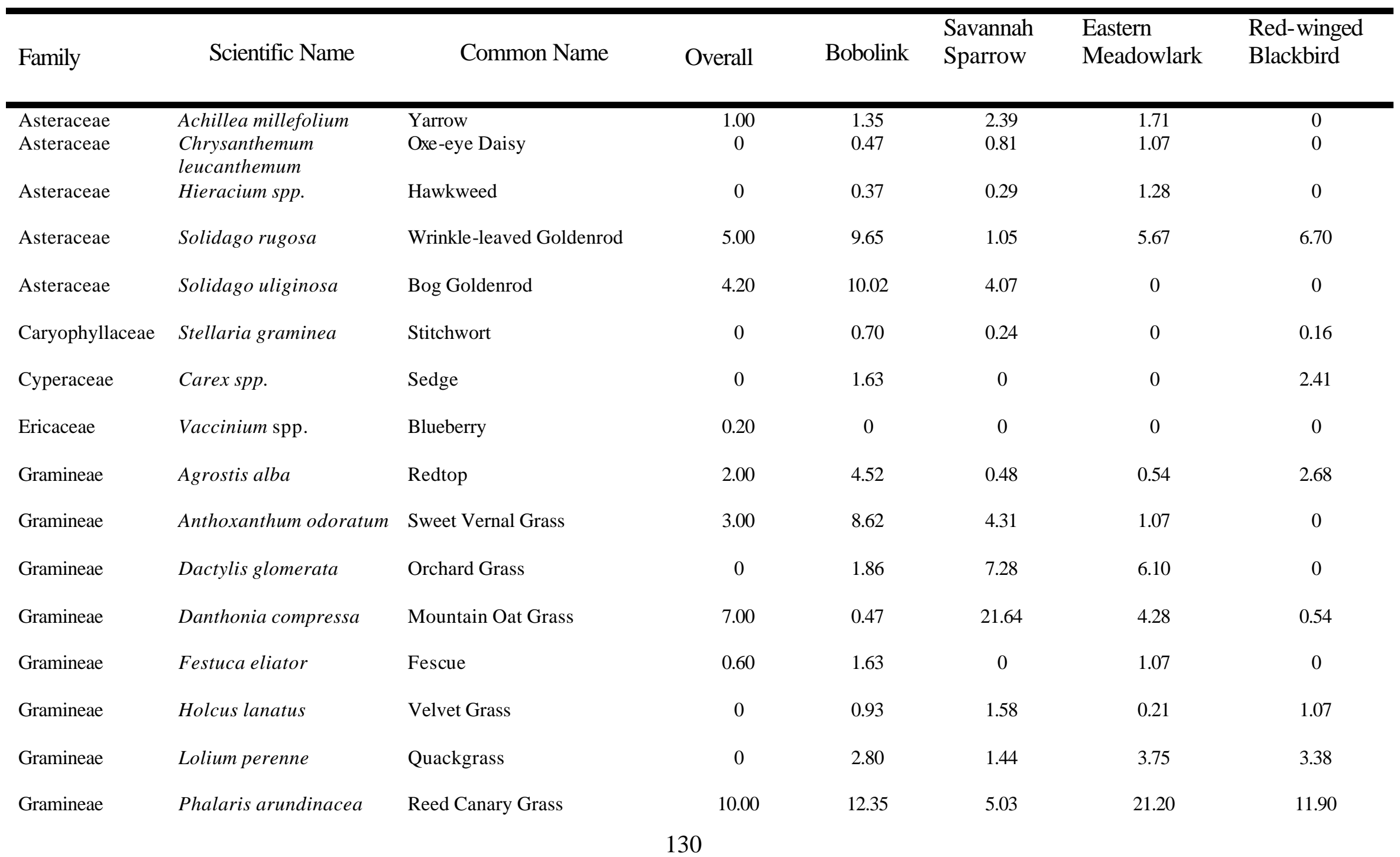


Appendix V. Continued

\begin{tabular}{|c|c|c|c|c|c|c|c|}
\hline Family & Scientific Name & Common Name & Overall & Bobolink & $\begin{array}{l}\text { Savannah } \\
\text { Sparrow }\end{array}$ & $\begin{array}{l}\text { Eastern } \\
\text { Meadowlark }\end{array}$ & $\begin{array}{l}\text { Red-winged } \\
\text { Blackbird }\end{array}$ \\
\hline Hypericaceae & Hypericum densiflorum & St. John's Wort & 1.00 & 0 & 0.24 & 0 & 0 \\
\hline Leguminosae & Lotus corniculatus & Birdsfoot Trefoil & 2.00 & 4.66 & 0.48 & 5.57 & 0.27 \\
\hline Leguminosae & Trifolium pratense & Clover & 0.40 & 1.03 & 0.38 & 0 & 0 \\
\hline Lycopodiaceae & Lycopodium spp. & Moss & 1.00 & 0 & 2.63 & 0 & 0 \\
\hline Ranunculaceae & Ranunculus spp. & Buttercup & 1.00 & 1.44 & 0.53 & 0.64 & 0.38 \\
\hline Rosaceae & Crataegus sp. & Hawthorne & 1.00 & 0 & 0.48 & 0 & 0 \\
\hline Rosaceae & Fragaria spp. & Wild Strawberry & 2.00 & 2.70 & 4.12 & 1.39 & 0.80 \\
\hline Rosaceae & Rubus spp. & Dewberry & 1.20 & 0.93 & 3.83 & 0 & 0 \\
\hline Rosaceae & Potentilla spp. & Cinquefoil & 6.90 & 4.01 & 18.53 & 7.92 & 0.27 \\
\hline Rosaceae & Spiraea alba & Narrow-leaved Meadowsweet & 15.90 & 0 & 0.24 & 0 & 57.80 \\
\hline Rubiaceae & Taraxacum officinale & Dandelion & 1.00 & 0.47 & 3.06 & 0.21 & 0.27 \\
\hline
\end{tabular}


Appendix VIa. Mean ( $\overline{\mathrm{x}}$ ) and standard error (SE) of vegetative characteristics found at bobolink nest sites and random sample locations on the Canaan Valley National Wildlife Refuge, Tucker County, West Virginia, 1999-2000. An asterisk denotes those variables that were not entered into the discriminant function analysis model.

\begin{tabular}{|c|c|c|c|c|c|c|c|}
\hline \multirow[b]{2}{*}{ Variable } & & \multicolumn{2}{|c|}{ Nest } & \multicolumn{2}{|c|}{ Random } & \multirow[t]{2}{*}{$F$-value } & \multirow[t]{2}{*}{$P$-value } \\
\hline & & $\overline{\mathrm{x}}$ & SE & $\bar{x}$ & SE & & \\
\hline \multirow{2}{*}{ Ground Cover } & Litter & 9.40 & 3.02 & 11.60 & 2.70 & 3.39 & 0.072 \\
\hline & Bare Ground & 0 & 0 & 4.00 & 1.53 & 8.58 & 0.005 \\
\hline Growth State (\%) & Standing Dead Vegetation & 4.52 & 1.37 & 1.60 & 0.80 & 4.07 & 0.049 \\
\hline \multirow[t]{6}{*}{ Cover Type } & Forbs & 42.92 & 5.18 & 38.60 & 5.00 & $*$ & $*$ \\
\hline & Grass & 47.68 & 4.70 & 43.60 & 5.57 & 1.85 & 0.180 \\
\hline & Wood & 0 & 0 & 2.20 & 1.64 & $*$ & $*$ \\
\hline & Vertical Density & 23.72 & 2.27 & 21.00 & 3.04 & $*$ & $*$ \\
\hline & Maximum Height & 57.72 & 4.35 & 47.84 & 4.43 & $*$ & $*$ \\
\hline & Litter Depth & 2.40 & 0.83 & 2.28 & 0.67 & $*$ & $*$ \\
\hline
\end{tabular}


Appendix VIb. Mean ( $\bar{x})$ and standard error (SE) of vegetative characteristics found at eastern meadowlark nest sites and random sample locations on the Canaan Valley National Wildlife Refuge, Tucker County, West Virginia 1999-2000. An asterisk denotes those variables that were not entered into the discriminant function analysis model.

\begin{tabular}{|c|c|c|c|c|c|c|c|}
\hline \multirow[b]{2}{*}{ Variable } & & \multicolumn{2}{|c|}{ Nest } & \multicolumn{2}{|c|}{ Random } & \multirow[t]{2}{*}{$F$-value } & \multirow[t]{2}{*}{$P$-value } \\
\hline & & $\bar{x}$ & SE & $\bar{x}$ & SE & & \\
\hline \multirow[t]{2}{*}{ Ground Cover } & Litter & 19.09 & 6.43 & 25.00 & 8.55 & $*$ & $*$ \\
\hline & Bare Ground & 0 & 0 & 4.55 & 3.66 & $*$ & $*$ \\
\hline Growth State $(\%)$ & Standing Dead Vegetation & 12.00 & 3.46 & 0.82 & 0.05 & 15.24 & 0.0009 \\
\hline \multirow[t]{6}{*}{ Cover Type } & Forbs & 23.45 & 5.36 & 37.36 & 8.52 & $*$ & * \\
\hline & Grass & 54.27 & 8.66 & 33.09 & 8.04 & $*$ & $*$ \\
\hline & Wood & 0.91 & 0.91 & 0 & 0 & $*$ & * \\
\hline & Vertical Density & 20.27 & 2.74 & 14.64 & 4.49 & $*$ & $*$ \\
\hline & Maximum Height & 56.36 & 6.94 & 37.00 & 6.64 & 18.44 & 0.0004 \\
\hline & Litter Depth & 4.45 & 1.06 & 1.00 & 0.30 & 6.37 & 0.021 \\
\hline
\end{tabular}


Appendix VIc. Mean ( $\overline{\mathrm{x}}$ ) and standard error (SE) of vegetative characteristics found at savannah sparrow nest sites and random sample locations on the Canaan Valley National Wildlife Refuge, Tucker County, West Virginia 1999-2000. An asterisk denotes those variables that were not entered into the discriminant function analysis model.

\begin{tabular}{|c|c|c|c|c|c|c|c|}
\hline \multirow[b]{2}{*}{ Variable } & & \multicolumn{2}{|c|}{ Nest } & \multicolumn{2}{|c|}{ Random } & \multirow[t]{2}{*}{$F$-value } & \multirow[t]{2}{*}{$P$-value } \\
\hline & & $\bar{x}$ & SE & $\bar{x}$ & SE & & \\
\hline \multirow[t]{2}{*}{ Ground Cover } & Litter & 18.48 & 3.19 & 26.80 & 4.12 & $*$ & $*$ \\
\hline & Bare Ground & 5.00 & 3.14 & 6.40 & 3.37 & $*$ & $*$ \\
\hline Growth State $(\%)$ & Standing Dead Vegetation & 6.92 & 3.02 & 1.20 & 0.60 & 7.16 & 0.010 \\
\hline \multirow[t]{6}{*}{ Cover Type } & Forbs & 3.46 & 4.42 & 34.08 & 5.54 & $*$ & $*$ \\
\hline & Grass & 44.24 & 4.61 & 30.60 & 4.59 & 3.55 & 0.066 \\
\hline & Wood & 2.48 & 1.63 & 2.12 & 1.19 & $*$ & $*$ \\
\hline & Vertical Density & 12.48 & 1.13 & 12.88 & 1.65 & 1.41 & 0.241 \\
\hline & Maximum Height & 37.92 & 3.80 & 34.60 & 3.06 & $*$ & $*$ \\
\hline & Litter Depth & 2.92 & 0.54 & 2.48 & 0.43 & $*$ & $*$ \\
\hline
\end{tabular}


Appendix VId. Mean ( $\bar{x}$ ) and standard error (SE) of vegetative characteristics found at red-winged blackbird nest sites and random sample locations on the Canaan Valley National Wildlife Refuge, Tucker County, West Virginia, 1999-2000. An asterisk denotes those variables that were not entered into the discriminant function analysis model.

\begin{tabular}{|c|c|c|c|c|c|c|c|}
\hline \multirow[b]{2}{*}{ Variable } & & \multicolumn{2}{|c|}{ Nest } & \multicolumn{2}{|c|}{ Random } & \multirow[t]{2}{*}{$F$-value } & \multirow[t]{2}{*}{$P$-value } \\
\hline & & $\bar{x}$ & SE & $\bar{x}$ & SE & & \\
\hline \multirow[t]{2}{*}{ Ground Cover } & Litter & 0.75 & 0.55 & 20.00 & 3.42 & 12.09 & 0.001 \\
\hline & Bare Ground & 0 & 0 & 14.00 & 5.84 & 1.50 & 0.229 \\
\hline Growth State $(\%)$ & Standing Dead Vegetation & 1.50 & 1.50 & 1.10 & 0.58 & $*$ & $*$ \\
\hline \multirow[t]{6}{*}{ Cover Type } & Forbs & 9.50 & 5.17 & 29.55 & 5.32 & 0.01 & 0.924 \\
\hline & Grass & 30.85 & 9.34 & 29.95 & 4.74 & 1.41 & 0.243 \\
\hline & Wood & 58.90 & $\begin{array}{c}11.0 \\
5\end{array}$ & 1.55 & 0.82 & 10.02 & 0.003 \\
\hline & Vertical Density & 73.10 & 6.00 & 19.75 & 5.11 & $*$ & $*$ \\
\hline & Maximum Height & 91.70 & 3.23 & 36.65 & 5.05 & 63.70 & $<0.001$ \\
\hline & Litter Depth & 0.65 & 0.65 & 2.65 & 0.84 & $*$ & $*$ \\
\hline
\end{tabular}


Appendix VId. Mean ( $\overline{\mathrm{x}}$ ) and standard error (SE) of vegetative characteristics found at successful and unsuccessful bobolink nest sites on the Canaan Valley National Wildlife Refuge, Tucker County, West Virginia, 1999-2000. An asterisk denotes those variables that were not entered into the discriminant function analysis model.

\begin{tabular}{|c|c|c|c|c|c|c|c|}
\hline \multirow[b]{2}{*}{ Variable } & & \multicolumn{2}{|c|}{ Successful } & \multicolumn{2}{|c|}{ Unsuccessful } & \multirow[t]{2}{*}{$F$-value } & \multirow[t]{2}{*}{$P$-value } \\
\hline & & $\bar{x}$ & SE & $\bar{x}$ & SE & & \\
\hline \multirow[t]{2}{*}{ Ground Cover } & Litter & 13.93 & 5.00 & 3.64 & 1.52 & $*$ & $*$ \\
\hline & Bare Ground & 0 & 0 & 0 & 0 & $*$ & $*$ \\
\hline Growth State (\%) & Standing Dead Vegetation & 7.86 & 3.58 & 3.00 & 1.13 & $*$ & $*$ \\
\hline \multirow[t]{6}{*}{ Cover Type } & Forbs & 0.37 & 0.07 & 50.73 & 7.74 & 2.29 & 0.144 \\
\hline & Grass & 49.29 & 6.37 & 45.91 & 7.35 & $*$ & $*$ \\
\hline & Wood & 0 & 0 & 0 & 0 & $*$ & $*$ \\
\hline & Vertical Density & 27.36 & 2.87 & 19.09 & 3.24 & 4.20 & 0.052 \\
\hline & Maximum Height & 63.64 & 6.03 & 50.18 & 5.72 & $*$ & $*$ \\
\hline & Litter Depth & 3.43 & 1.39 & 1.09 & 0.51 & $*$ & $*$ \\
\hline
\end{tabular}


Appendix VIe. Mean ( $\bar{x}$ ) and standard error (SE) of vegetative characteristics found at successful and unsuccessful red-winged blackbird nest sites on the Canaan Valley National Wildlife Refuge, Tucker County, West Virginia 1999-2000. An asterisk denotes those variables that were not entered into the discriminant function analysis model.

\begin{tabular}{|c|c|c|c|c|c|c|c|}
\hline \multirow[b]{2}{*}{ Variable } & & \multicolumn{2}{|c|}{ Successful } & \multicolumn{2}{|c|}{ Unsuccessful } & \multirow[t]{2}{*}{$F$-value } & \multirow[t]{2}{*}{$P$-value } \\
\hline & & $\bar{x}$ & SE & $\bar{x}$ & SE & & \\
\hline \multirow[t]{2}{*}{ Ground Cover } & Litter & 1.00 & 1.00 & 0.50 & 0.50 & $*$ & $*$ \\
\hline & Bare Ground & 0 & 0 & 0 & 0 & $*$ & $*$ \\
\hline Growth State (\%) & Standing Dead Vegetation & 0 & 0 & 3.00 & 3.00 & $*$ & $*$ \\
\hline \multirow[t]{6}{*}{ Cover Type } & Forbs & 17.50 & 9.81 & 1.50 & 1.50 & $*$ & $*$ \\
\hline & Grass & 41.50 & 13.99 & 20.70 & 12.08 & $*$ & $*$ \\
\hline & Wood & 40.00 & 16.33 & 77.80 & 13.03 & 2.85 & 0.109 \\
\hline & Vertical Density & 68.60 & 9.67 & 77.60 & 7.36 & $*$ & $*$ \\
\hline & Maximum Height & 94.10 & 3.39 & 89.30 & 5.60 & 5.89 & 0.027 \\
\hline & Litter Depth & 1.30 & 1.30 & 0 & 0 & $*$ & $*$ \\
\hline
\end{tabular}


Appendix VIf. Mean and standard error of vegetative characteristics found at successful and unsuccessful savannah sparrow nest sites on the Canaan Valley National Wildlife Refuge, Tucker County, West Virginia 1999-2000. An asterisk denotes those variables that were not entered into the discriminant function analysis model.

\begin{tabular}{|c|c|c|c|c|c|c|c|}
\hline \multirow[b]{2}{*}{ Variable } & & \multicolumn{2}{|c|}{ Successful } & \multicolumn{2}{|c|}{ Unsuccessful } & \multirow[t]{2}{*}{$F$-value } & \multirow[t]{2}{*}{$P$-value } \\
\hline & & $\bar{x}$ & $\mathrm{SE}$ & $\bar{x}$ & SE & & \\
\hline \multirow[t]{2}{*}{ Ground Cover } & Litter & 19.58 & 5.98 & 17.54 & 2.93 & $*$ & $*$ \\
\hline & Bare Ground & 0 & 0 & 4.23 & 2.99 & 1.79 & 0.196 \\
\hline Growth State (\%) & Standing Dead Vegetation & 4.58 & 1.65 & 9.08 & 5.66 & $*$ & $*$ \\
\hline \multirow[t]{6}{*}{ Cover Type } & Forbs & 36.25 & 5.37 & 36.24 & 6.78 & $*$ & $*$ \\
\hline & Grass & 43.75 & 7.05 & 40.85 & 6.93 & 2.30 & 0.144 \\
\hline & Wood & 0.01 & 0.01 & 0.01 & 0.01 & $*$ & $*$ \\
\hline & Vertical Density & 12.13 & 1.41 & 12.77 & 1.80 & 5.79 & 0.025 \\
\hline & Maximum Height & 45.83 & 6.93 & 30.62 & 2.38 & 4.60 & 0.043 \\
\hline & Litter Depth & 3.08 & 1.03 & 2.77 & 0.47 & 0.65 & 0.430 \\
\hline
\end{tabular}


Appendix VII. Biomass (g) of invertebrates found on the Canaan Valley National Wildlife Refuge, Tucker County, West Virginia, 1999-2000.

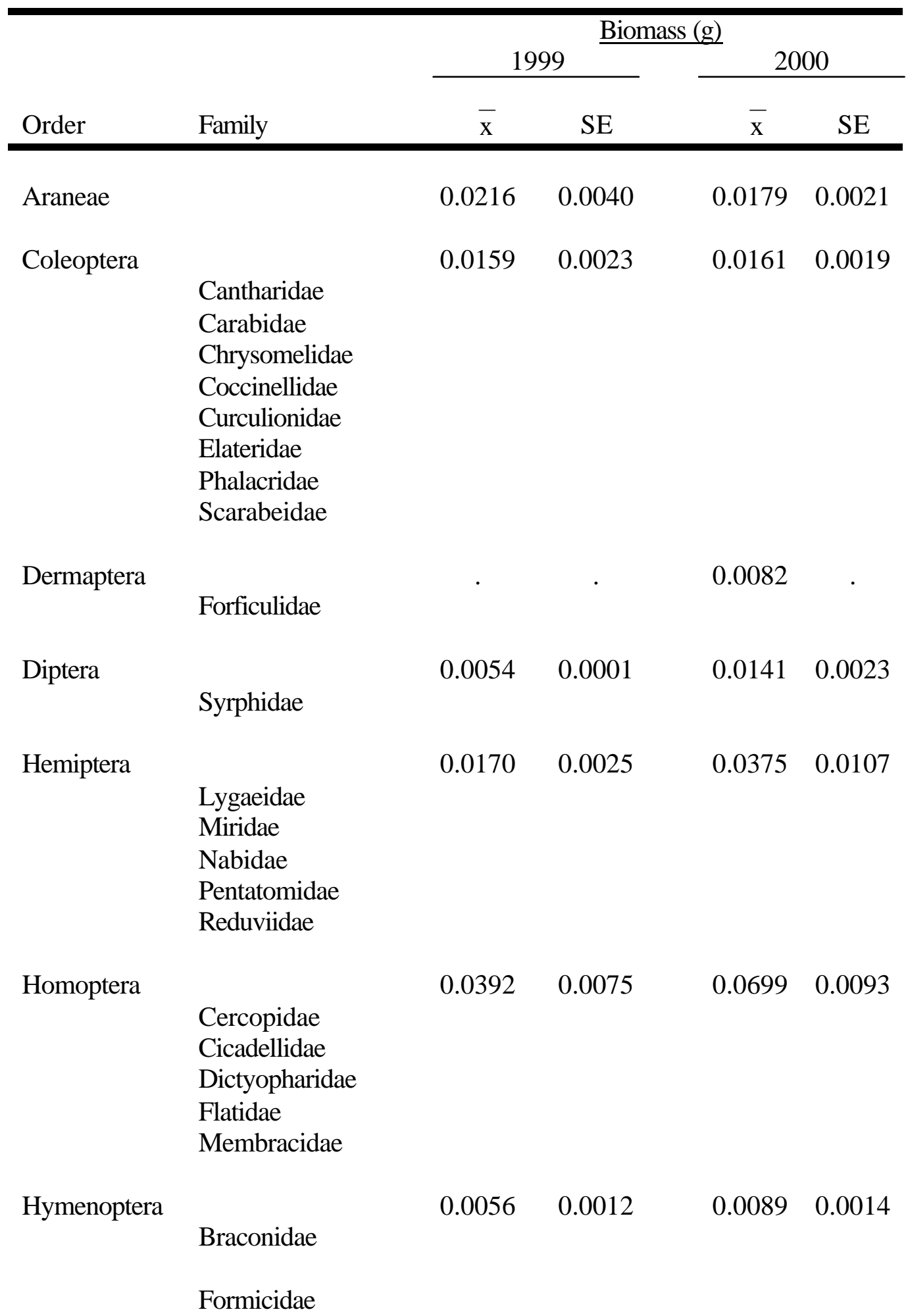




\begin{tabular}{|c|c|c|c|c|c|}
\hline \multirow[b]{3}{*}{ Order } & \multirow[b]{3}{*}{ Family } & \multicolumn{4}{|c|}{ Biomass (g) } \\
\hline & & \multicolumn{2}{|c|}{1999} & \multicolumn{2}{|c|}{2000} \\
\hline & & $\bar{x}$ & SE & $\overline{\mathrm{X}}$ & SE \\
\hline & Ichneumonidae & & & & \\
\hline Larvae & & 0.0192 & 0.0035 & 0.0191 & 0.0041 \\
\hline Lepidoptera & & 0.0108 & 0.0021 & 0.0218 & 0.0046 \\
\hline Neuroptera & & 0.0086 & 0.0046 & 0.0041 & 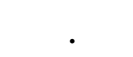 \\
\hline & Chrysopidae & & & & \\
\hline Orthoptera & & 0.0500 & 0.0100 & 0.0382 & 0.0117 \\
\hline & Acrididae & & & & \\
\hline & Tettigonidae & & & & \\
\hline Palpigrada & & 0.0152 & 0.0063 & . & . \\
\hline
\end{tabular}




\section{KELLY A. WARREN}

1999 - 2000 West Virginia University Morgantown, WV

Master of Science in Fisheries and Wildlife Resources (May 2001)

GPA: 4.0 cumulative

1995 - 1998 University of Missouri Columbia, MO

Bachelor of Science in Fisheries and Wildlife / Biological Science Minor

GPA: 3.2 cumula tive

1994 - 1995 Lincoln University Jefferson City, MO

Natural Resources Major

GPA: 3.7

\section{PROFESSIONAL EXPERIENCE}

Job Title: Master's Research, Grassland Ecology in Canaan Valley, West Virginia

Dates of Employment: May 1999 to present

Employer: West Virginia University, P. O. Box 6125, Morgantown, WV, 26505

Advisor: James T. Anderson, Ph.D

Collected detailed information on breeding grassland bird populations on the Canaan Valley National Wildlife Refuge in Canaan Valley, West Virginia in partial fulfillment of a Master of Science degree in Fisheries and Wildlife Resources at West Virginia University.

Conducted weekly strip transect surveys to determine abundance, diversity, and species richness of breeding birds found on grasslands. Specifically, determined abundance and nest success of bobolinks, savannah sparrows, eastern meadowlarks, and red-winged blackbirds.

Identified and recorded vegetation to determine dominant species found on the grassland portions of the refuge. Additionally, vegetation information was collected on bird survey transects and at inactive nest sites using a Robel pole and Daubenmire frame to determine percent vegetative composition. 
Invertebrate information was collected using the grassland sweepnet sampling technique to determine prey base for nestlings and insectivorous grassland birds.

Assisted Canaan Valley National Wildlife Refuge personnel in breeding anuran and northern flying squirrel surveys.

Volunteered at the Canaan Valley National Wildlife Refuge and aided in cave gate construction projects during the summers of 1999 and 2000. Duties involved: carrying heavy equipment, working on adverse terrain, and welding.

Job Title: Guest Lecturer for Wildlife Habitat Techniques

Dates of Employment: September 1999 to present

Employer: West Virginia University

Advisor: James T. Anderson, Ph.D

Gave guest lectures on invertebrate sampling techniques and grassland management and ecology (Fall 1999 and Fall 2000) for Division of Forestry Wildlife Habitat Techniques class.

Designed invertebrate sampling laboratory for the Division of Forestry Wildlife Habitat Techniques class (Fall 1999 and Fall 2000). Demonstrated the use of core samplers, surber samplers, sweepnets, and kicknet samplers, pitfall traps, light traps, and other invertebrate collection techniques.

Job Title: Division of Forestry Graduate Research Assistant

Dates of Employment: August 2000 to present

Employer: West Virginia University

Advisor: James T. Anderson, Ph.D

Collected information from Region 5 U.S. Fish and Wildlife Service National Wildlife Refuges on waterfowl use days for different impoundment treatments. Determining waterfowl use days by collecting seed heads from dominant seed producing plants and collecting invertebrates.

Designed protocols for waterfowl surveys, seed and invertebrate collection.

Collaborated with refuge biologists on impoundment conditions and time to begin sampling.

Identified and collected seed heads from the top five seed producing plants in treatment and control impoundments at each refuge. Plant species include: Polygonum pennsylvanicum, Polygonum hydropiper, Polygonum hydropiperoides, Polygonum lapathofolium, Polygonum saggitatum, Panicum spp., Bidens cernua, Echinochloa walteri, Leersia oryzoides, Decadon sp., Eliocharis spp, Cyperus spp., Leptochloa sp., 
Scirpus spp., etc.

Collected seeds were processed to determine productivity.

Collected invertebrates at 30 randomly assigned locations within each impoundment using a $15 \mathrm{~cm}$ Core sampler. Samples were processed in the lab and overall productivity was determined.

Job Title: Division of Biology Teaching Assistant

Dates of Employment: August 1999 - May 2000

Employer: West Virginia University

Advisor: James McGraw, Ph.D., and Keith Garbutt, Ph.D

General Biology (Biology 15) Laboratory Instructor. Laboratory exercises on: DNA fingerprinting, 3 point mapping, fruit fly genetic drift and selection, seed germination, and osmotic potential. Taught students to analyze data using basic statistics (T-tests, G-tests) and to write scientific papers based on their experiments.

Ecology and Evolution (Biology 21) Laboratory Instructor. Taught students to write proposals based on National Science Foundation guidelines, to set-up factorial designs, to set-up and conduct experiments approved by a mock NSF panel, to analyze data using analysis of variance (ANOVA), to write a scientific manuscript stating the results of their experiment and discussing the overall meaning, and to make posters and/or presentations using Microsoft Powerpoint for a symposium a the end of the school year.

Job Title: Naturalist, Manager

Dates of Employment: November 1998 - April 1999

Employer: World Bird Sanctuary (WBS)

Supervisor: Walter Crawford

Handler and caretaker of various birds of prey, reptiles, and small mammals.

Manager of the Clarksville Eagle Center, a field station of the WBS (March 1999-April 1999).

Handler and caretaker of reptiles and small mammals.

Gave planned and impromptu educational programs on the natural history of birds of prey, small mammals, and reptiles in the Clarksville Eagle Center.

Designed and organized nature displays.

Job Title: Research Assistant, Wood Thrush Dispersal and Breeding Forest Bird Project

Dates of Employment: May 1998 - August 1998 
Employer: University of Missouri, Biological Sciences Department

Supervisor: Mark Fink of John Faaborg, Ph.D

Identified forest birds by site and sound.

Identified forest plant species.

Conducted double observer point counts according to BBIRD protocol.

Located male Wood Thrush territories and searched for nearby nests.

Searched for and monitored other forest bird nests in conjunction with the BBIRD project

Attached radio transmitters and banded nestling wood thrush with leg bands.

Measured the amount of cover and type of vegetation at the nest site and each location the fledglings were found while radio tracking, using BBIRD protocol. Determined the number countable trees and measured basal area (used a prism and Biltmore stick), percent canopy, and percent ground cover.

Worked on adverse terrain with he aid of topographical maps to find Wood Thrush territories.

Job Title: Independent Study Project

Dates of Employment: January 1998 - June 1998

Employer: University of Missouri, Department of Fisheries and Wildlife

Advisor: Mark Ryan, Ph.D.

Research was conducted on Tucker Prairie, Callaway County, Missouri

The study was implemented using artificial nests and small brown chicken eggs to determine the rates that larger predators might depredate nests along fire lanes and prairie edges.

Job Title: Research Assistant, Grassland Bird Research Project

Dates of Employment: May 1997 - August 1997

Employer: University of Missouri, Biological Sciences Department

Supervisor: Maiken Winter, Ph.D. of John Faaborg, Ph.D

Identified grassland bird species by site and sound during strip transect surveys.

Identified plant species.

Research conducted on Missouri Department of Conservation and The Nature Conservancy managed prairies in Southwest Missouri

The species studied were Henslow sparrows, dickcissels, Eastern meadowlarks, and grasshopper sparrows.

Nest searched by locating male territories and chipping female Henslow 
sparrows and dickcissels.

Set up mammal plates covered in acetylene smoke to check for predator density along the forest edge of the prairies.

Collected data on nest vegetation, with the use of a Robel pole and Daubenmire frame, on inactive nests.

Collected vegetation information on transects using a Robel pole and Daubenmire frame to determine the height of the vegetation at random points to either side of the transects.

Job Title: Substitute Teacher

Dates of Employment: January 1994 - August 1996

Employer: Jefferson City Public School System

Supervisor: Ms. Donna Sentilles

Substitute teacher for grades kindergarten through 12, in all subjects (19951998).

Job Title: Research Assistant

Dates of Employment: June 1994 - August 1996

Employer: Center of Excellence Initiative for Wildlife Damage Management, Lincoln University, Jefferson City, MO

Supervisor: Russell Reidinger, Ph.D.

Wrote a literature review on food aversion learning and its use in wildlife damage management.

Assisted the National Wildlife Research Research Center, Sandusky, OH on a research experiment that involved: handling and pulling primary flight feathers of geese, setting up a controlled experiment with timed observations, and performed descriptive statistical analysis.

Prepared bird mounts for the study skin collection at Lincoln University, MO (Summer 1996).

Job Title: Teacher / Choreographer

Dates of Employment: September 1992 - May 1996

Employer: Theressa Ferguson's School of Dance, Jefferson City, MO

Supervisor: Ms. Theressa Ferguson

Structured and instructed dance classes for all ages.

Job Title: Biological Technician

Dates of Employment: May 1995 - August 1995 
Employer: Wildlife Services, Columbia, MO

Supervisor: Mr. Ed Hartin

Assisted with a St. Louis Encephalitis detection project: traveled to areas within the state impacted by the flood of 1993. Mist-netted, banded, and drew blood from sparrows, grackles, and red-winged blackbirds. Blood samples were sent to a lab samples for analysis.

Certified in airport bird identification: assisted in teaching a bird identification course at the St. Louis International Airport.

Assisted in sexing and banding waterfowl.

Aided in animal damage and exotic species management throughout Missouri.

Assisted in animal control measures.

Submitted biweekly reports for the directors review.

Job Title: Research Assistant

Dates of Employment: June 1993 - August 1993

Employer: Lincoln University, Jefferson City, MO

Supervisor: Russell Reidinger, Ph.D.

Tested water quality at Moreau River in Cole County, MO.

Helped with plant identification at Ha Ha Tonka State Park and Ozark Scenic Riverways, MO.

Learned to press, mount, and label plant species.

Finished with a research project on the flood of 1993, took pictures, interviewed authorities at Department of Natural Resources and Missouri Public Health Department, and made a video document of the flood.

\section{PUBLICATIONS}

Warren, K. A., and M. R. Ryan. 1999. Do internal fire lanes affect nest depredation rates in prairies? Prairie Naturalist 31:215-220.

Warren, K. A., and J. T. Anderson. 2000. Grassland bird diversity and abundance in Central Appalachia. The Wildlife Society National Conference, Nashville, TN. 
Warren, K. A. 2000. Grassland birds of Canaan Valley: Their nests, eggs, and nestlings. Friends of Canaan Valley National Wildlife Refuge Series, Canaan Valley, WV.

Warren, K. A., and J. T. Anderson. 2000. Grassland bird abundance and nest success in Canaan Valley. Northeastern Wildlife and Fisheries Conference, Charleston, WV.

Warren, K. A., and J. T. Anderson. 1999. Grassland bird ecology in Canaan Valley, West Virginia. Fall meeting of the West Virginia Partners in Flight, Huntington, WV. 